\title{
Meteorological Monitoring on Bikini Atoll: System Description and Data Summary (May 2000-April 2001)
}

F.Gouveia, R. Bradsher, J. Brunk, $W$. Robison, and T. Hamilton

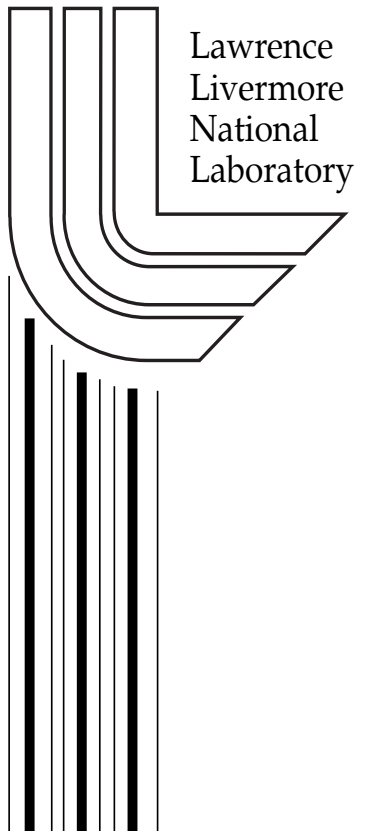

January 1, 2002 


\section{DISCLAIMER}

This document was prepared as an account of work sponsored by an agency of the United States Government. Neither the United States Government nor the University of California nor any of their employees, makes any warranty, express or implied, or assumes any legal liability or responsibility for the accuracy, completeness, or usefulness of any information, apparatus, product, or process disclosed, or represents that its use would not infringe privately owned rights. Reference herein to any specific commercial product, process, or service by trade name, trademark, manufacturer, or otherwise, does not necessarily constitute or imply its endorsement, recommendation, or favoring by the United States Government or the University of California. The views and opinions of authors expressed herein do not necessarily state or reflect those of the United States Government or the University of California, and shall not be used for advertising or product endorsement purposes.

This work was performed under the auspices of the U. S. Department of Energy by the University of California, Lawrence Livermore National Laboratory under Contract No. W-7405-Eng-48.

This report has been reproduced directly from the best available copy.

Available electronically at http://www.doc.gov/bridge

Available for a processing fee to U.S. Department of Energy

And its contractors in paper from

U.S. Department of Energy

Office of Scientific and Technical Information

P.O. Box 62

Oak Ridge, TN 37831-0062

Telephone: (865) 576-8401

Facsimile: (865) 576-5728

E-mail: reports@adonis.osti.gov

Available for the sale to the public from

U.S. Department of Commerce

National Technical Information Service

5285 Port Royal Road

Springfield, VA 22161

Telephone: (800) 553-6847

Facsimile: (703) 605-6900

E-mail: orders@ntis.fedworld.gov

Online ordering: http://www.ntis.gov/ordering.htm

OR

Lawrence Livermore National Laboratory

Technical Information Department's Digital Library

http://www.llnl.gov/tid/Library.html 
Meteorological Monitoring on Bikini Atoll:

System Description and Data Summary(May 2000 - April 2001)

\author{
Frank Gouveia \\ Rayla Bradsher \\ James Brunk \\ William Robison \\ Terry Hamilton
}

Manuscript Date: January 2002

\title{
Lawrence Livermore National Laboratory
}

University of California • Livermore, CA • 94551 


\section{Table of Contents}

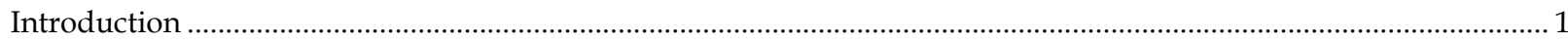

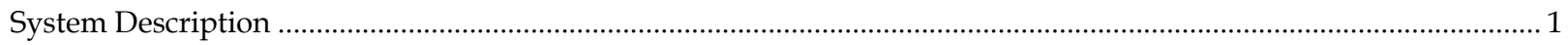

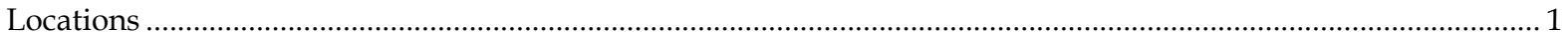

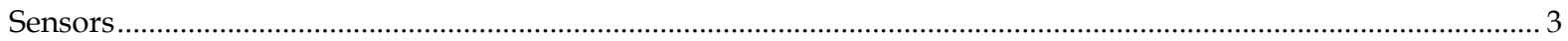

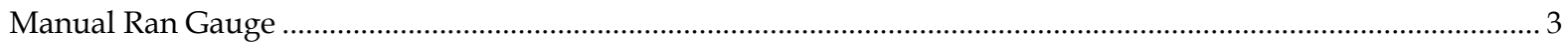

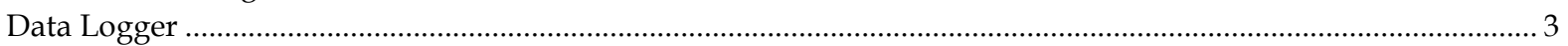

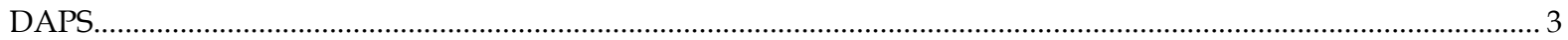

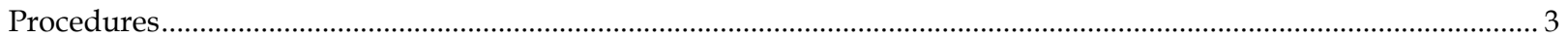

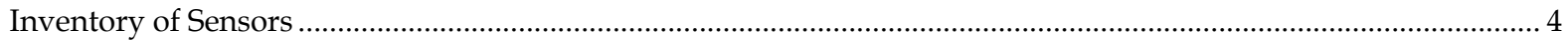

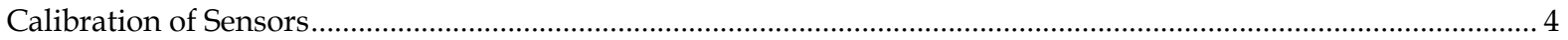

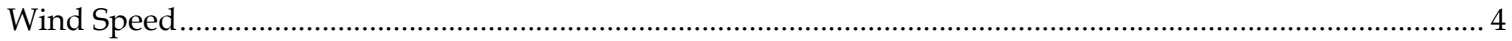

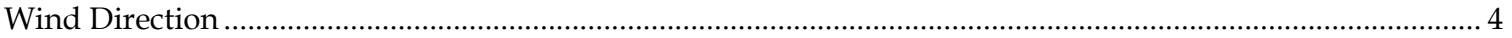

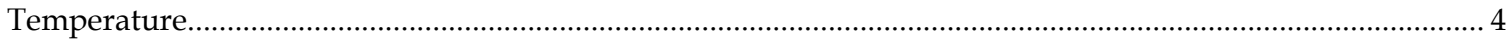

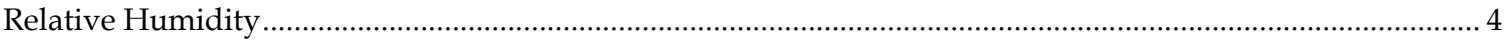

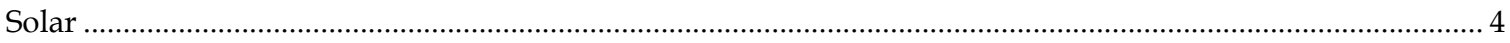

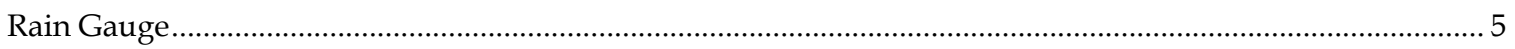

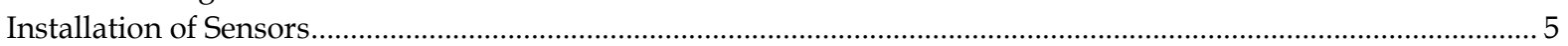

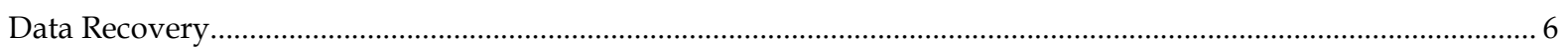

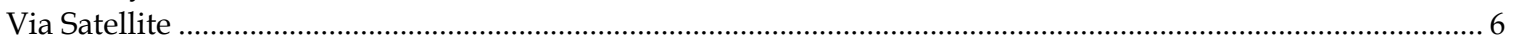

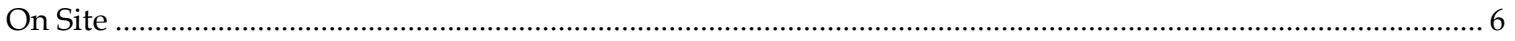

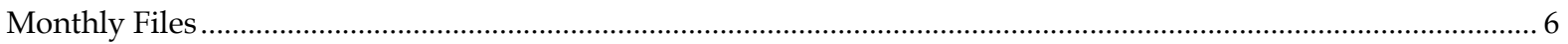

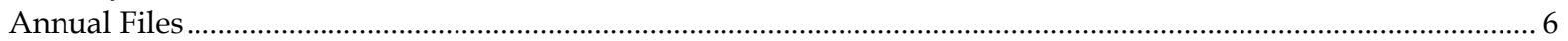

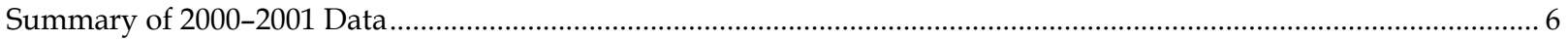

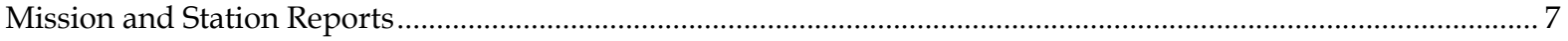

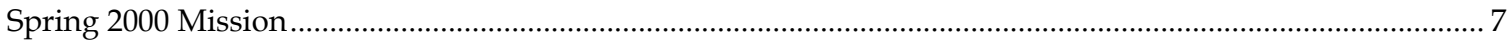

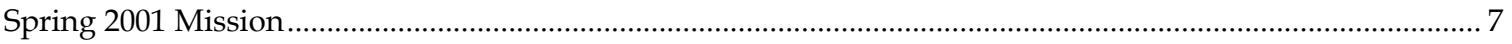

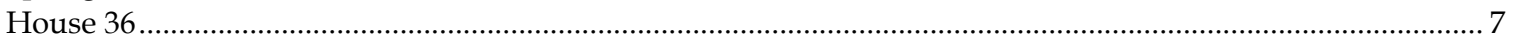

Control Plot

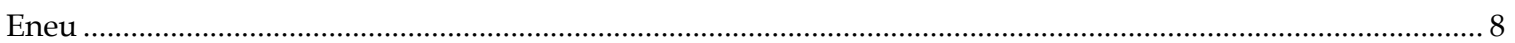

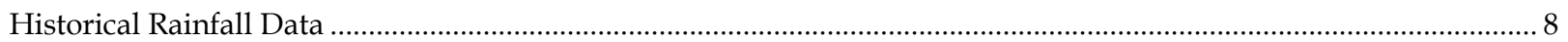

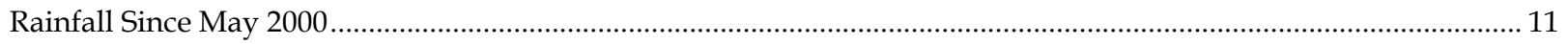

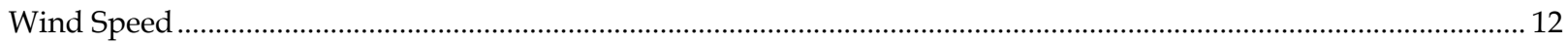

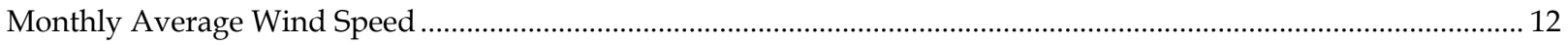

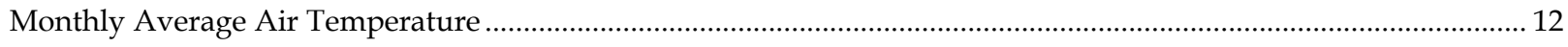

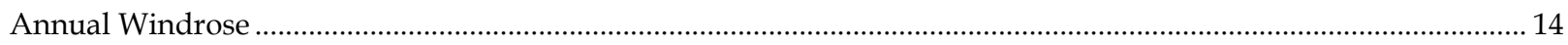

Summary 15

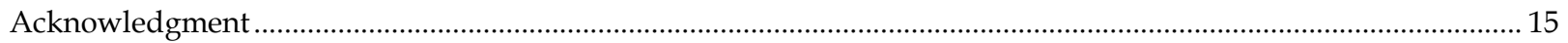

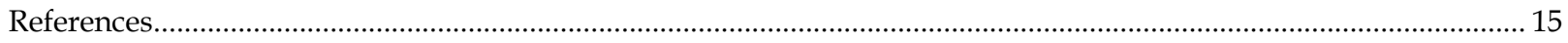




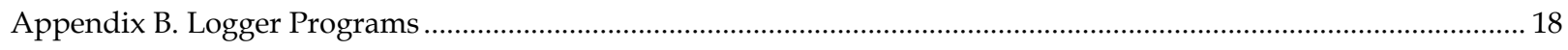

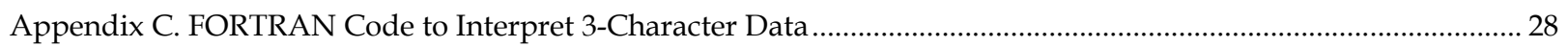

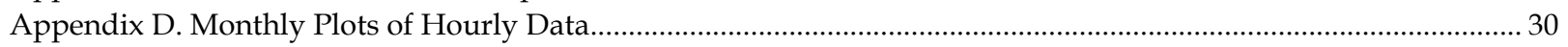

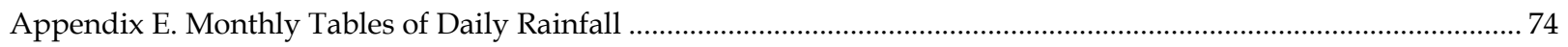

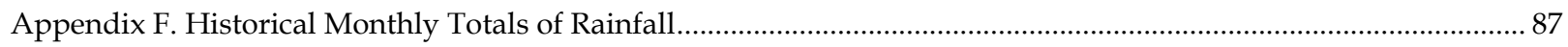

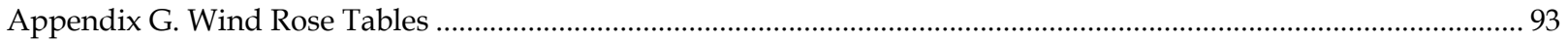

\section{List of Tables}

Table 1. Brief description of the meteorological stations currently located on Bikini Atoll. ....................................... 2

Table 2. List of variables measured at each station and the type of sensors used...................................................... 3

Table 3. List of sensors used by the Marshall Islands Program............................................................................... 5

Table 4. Interpretation of the DAPS download message string. ….................................................................. 7

Table 5. Historical values of the annual total rain (inches) for the Bikini Atoll gauges. ........................................... 9

Table 6. Historical values of monthly average rain (inches) for Bikini Atoll gauges. ............................................... 11

\section{List of Figures}

Figure 1. Map of Bikini Island with the locations of meteorological stations. ........................................................ 2

Figure 2. Map of Eneu Island with the location of the meteorological station........................................................ 2

Figure 3. Comparison of Relative Humidity as measures at the Control Plot and House 36 stations......................... 9

Figure 4. Annual total rainfall for the year 1985 through 2000 from the Bikini Island average................................... 10

Figure 5. Monthly average of rain based on the best estimate of all Bikini Island data............................................ 10

Figure 6. Cumulative daily values of rainfall for the six rain gauges on Bikini Atoll for the period starting 6 May 2000 through 30 April 2001.

Figure 7. Histogram of cumulative frequency of wind speed class using all available data from May 2000 through April 2001.

Figure 8 . The monthly average wind speed from three Bikini Atoll stations.

Figure 9. The monthly average air temperature from three Bikini Atoll stations, and the monthly maximum and minimum temperature from the Control Plot station. 


\section{Meteorological Monitoring on Bikini Atoll: System Description and Data Summary (May 2000 - April 2001)}

Frank Gouveia, Rayla Bradsher, Jim Brunk, William Robison and Terry Hamilton

\section{Introduction}

\begin{abstract}
Meteorological data are continuously collected at three sites on Bikini Atoll in support of radioecological research and monitoring programs conducted by the Health and Ecological Assessments Division at the Lawrence Livermore National Laboratory (LLNL). Weather stations were first established on Bikini Atoll in April 1990, and provide information on rainfall, wind speed and direction, air temperature, humidity, and solar radiation. These data and information are used to interpret results of remediation experiments designed to evaluate the effectiveness of potassium fertilizer on reducing the uptake of ${ }^{137} \mathrm{Cs}$ into locally grown foods. We have also demonstrated that ${ }^{137} \mathrm{Cs}$ is slowly leached from surface soil by the action of rain water. Long-term meteorological data are crucial to our efforts of developing an understanding of environmental processes controlling the environment loss of ${ }^{137} \mathrm{Cs}$ in coral atoll soil.
\end{abstract}

In May 2000, older data collection platforms and the DOS-based system that downloaded data from National Oceanic \& Atmospheric Administration (NOAA)'s Data Automatic Processing System (DAPS) was decommissioned, and new data loggers, GOES (Geostationary Operational Environmental Satellite) transmitters and antennas were installed. Consequently, new procedures were developed to maintain the field systems, download the data, and reduce and archive the data.

This document provides an operational description and status report on the three new meteorological monitoring systems on Bikini Atoll as well as an computational summary of previously recorded data. Included are overviews of procedures for sensor exchange, data recovery and reduction, and specific information about the different sensors. We also provide a description of systems maintenance and trouble shooting activities. This report will be updated on an annual basis.

\section{System Description}

\section{Locations}

Currently, there are three stations on Bikini Atoll: two on Bikini Island and one on Eneu Island (Table 1). The locations were chosen several years ago, and are good representations of meteorological conditions over the land surface.

As typical for a Pacific Ocean atoll, the topography around the meteorological stations is very level. The primary obstruction to the ambient airflow would come from the mature coconut trees (710 meters) and underbrush. The prevailing trade winds come from the ENE (about $70^{\circ}$ ), and this is considered the upwind direction in this paper. Figure 1 is a map of Bikini Island showing the locations of the Control Plot and House 36 stations. The Eneu station is shown in Figure 2, which is a map of Eneu Island.
The immediate surface near the Control Plot station is covered with short grasses. The closest trees are $8 \mathrm{~m}$ from the tower towards the North and West, and about $50 \mathrm{~m}$ to the East.

Although the House 36 station is near the lagoon, it is about $150 \mathrm{~m}$ in the downwind direction from the tree line. The area around House 36 features sandy soil surfaces and very little vegetation.

The Eneu Island station is about $15 \mathrm{~m}$ upwind of a one-story building. The trees are about $30 \mathrm{~m}$ upwind of the Eneu station. These trees are not very close together, and the grove has very little underbrush to restrict airflow. 
Table 1. Description of the meteorological stations currently located on Bikini Atoll.

\begin{tabular}{|c|c|c|c|c|c|}
\hline Station name & Island & Latitude & Longitude & $\begin{array}{l}\text { Upwind distance } \\
\text { to waterline }(\mathrm{m})\end{array}$ & Remarks \\
\hline Control Plot & Bikini & $11^{\circ} 37^{\prime} 44^{\prime \prime} \mathrm{N}$ & $165^{\circ} 32^{\prime} 50^{\prime \prime} \mathrm{E}$ & 500 & Small clearing of dense trees \\
\hline House 36 & Bikini & $11^{\circ} 37^{\prime} 40^{\prime \prime} \mathrm{N}$ & $165^{\circ} 32^{\prime} 32^{\prime \prime} \mathrm{E}$ & 1000 & Broad clearing near lagoon \\
\hline Eneu Island & Eneu & $10^{\circ} 31^{\prime} 29^{\prime \prime} \mathrm{N}$ & $165^{\circ} 33^{\prime} 59^{\prime \prime} \mathrm{E}$ & 200 & $\begin{array}{l}\text { In large clearing of sparse trees } \\
\text { near center of island }\end{array}$ \\
\hline
\end{tabular}

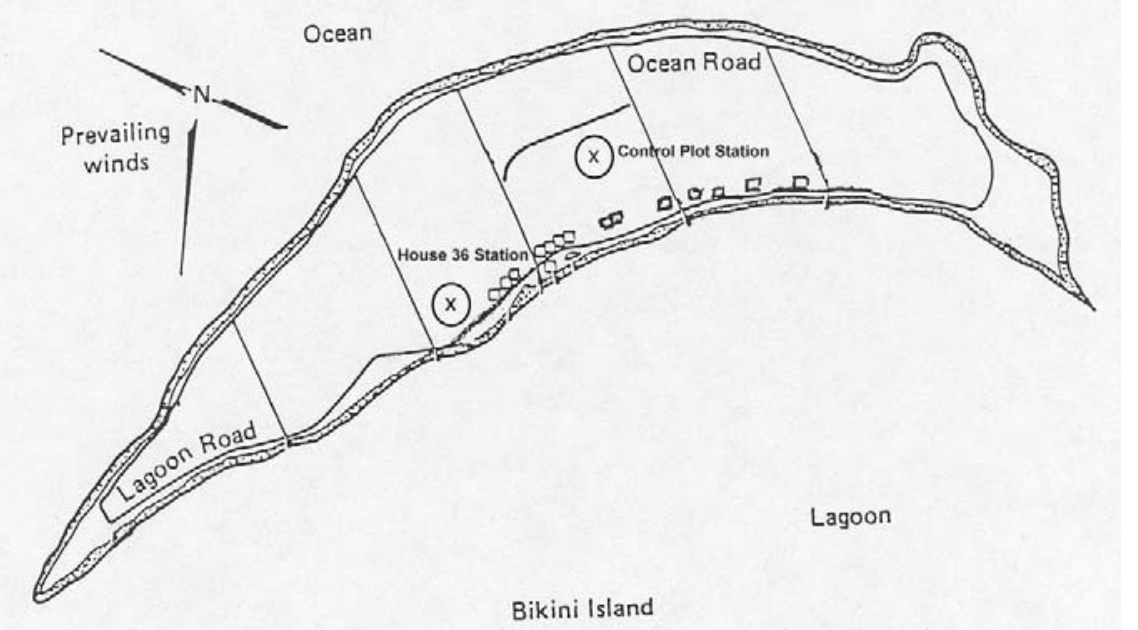

Figure 1. Map of Bikini Island with the locations of meteorological stations.
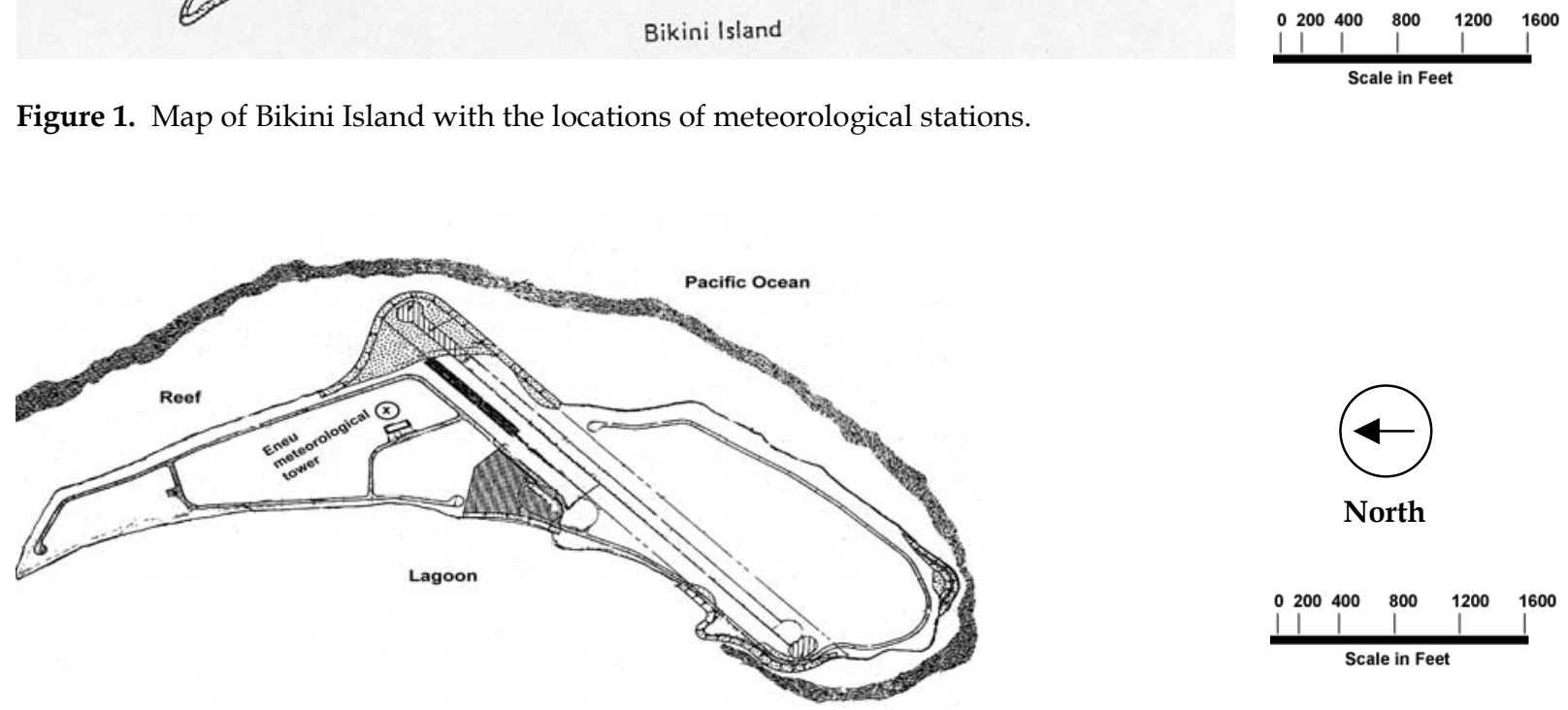

Figure 2. Map of Eneu Island with the location of meteorological station. 


\section{Sensors}

Each system features sensors for wind, air temperature and humidity, solar radiation, and rain (Table 2). The anemometers are mounted at the top of 10-m towers. The air temperature and humidity sensors are inside naturally aspirated solar shields, and located about $3 \mathrm{~m}$ above the ground. The solar sensor is located about $3 \mathrm{~m}$ above the ground on a crossarm extending from the tower towards the South. Each station includes two rain gauges. Five of the six rain gauges are within $10 \mathrm{~m}$ of their respective tower. The exception is the House 36 station that has a rain gauge on the Excavation Plot as well as near the tower base.

\section{Manual Rain Gauge}

A rain gauge near the DOE station on Bikini Island is read every day at $7 \mathrm{pm}$. The daily total of rain is recorded in a logbook, the information copied and sent onto LLNL.

\section{Data Logger}

The wiring diagram appears in Appendix A. The same wiring scheme is used for all three loggers. We are using Campbell Scientific CR10X data loggers.
Appendix B presents the logger programs used for each station. The sensors are polled every ten seconds with averages computed every hour. Additionally, the standard deviation of the wind direction, cumulative rainfall, and daily rainfall are computed and retained. These data are sent to the GOES transmitter. Every three hours, according to the programmed schedule, the data are transmitted to the GOES-W satellite. The loggers have the capacity for over three years of data.

\section{DAPS}

The data sent to the GOES satellite are transferred to NOAA's Wallops Command and Data Acquisition Station. The data can be downloaded via their web site (http://dcs.noaa.gov/). Downloading requires first contacting the DAPS / DCS (Data Collection System) staff (Email: daps@wcda.wff.nasa.gov). The IP address of your download computer is needed along with the DAPS account name (LLL18W), and an e-mail address for communication.

The downloaded file should have a file name that identifies the date of the download. For example the file name for data downloaded on April 30, 2001 was B010430.TXT.

\section{Procedures}

Development of a detailed operations and training manual for the meteorological stations was beyond the scope of this paper. This section describes in general terms how to calibrate and install the meteorological sensors, and retrieve data from the systems.

Table 2. List of variables measured at each station and the type of sensors used.

\begin{tabular}{llll}
\hline \multicolumn{1}{c}{ Variable } & \multicolumn{1}{c}{ Sensor type } & Model & Remarks \\
\hline Wind speed & 3-cup & Handar 430 & Starting threshold $\sim 0.5 \mathrm{~m} / \mathrm{s}$ \\
Wind direction & Vane & Handar 431 & Starting threshold $\sim 0.5 \mathrm{~m} / \mathrm{s}$ \\
Air temperature & Thermistor & Handar 435 & YSI 44006 element \\
Relative humidity & Thin-film capacitor & Handar 435 & Vaisala Humicap element \\
Incoming solar radiation & Silicon photodiode & Licor 200 & Measures light level \\
Rainfall & Tipping bucket & Various & 0.01 per tip \\
\hline
\end{tabular}




\section{Inventory of Sensors}

At this time, there are many sensors stored at LLNL and on Bikini Island that can be used in the field. Table 3 is an inventory of the sensors that are part of the Marshall Islands Program. Although most of the individual items in this table are ready for field use, some may require repair, or are beyond repair and should be decommissioned. In time, the unusable sensors will be fixed and stored, or salvaged and taken off the inventory. The temperature sensors listed in Table 3 will be held in reserve, and may be fielded when the relatively fragile, temperature and relative humidity sensors do not perform properly.

\section{Calibration of Sensors}

The meteorological sensors are calibrated and checked following the guidelines in EPA (1990). Before installation, each sensor is checked for damage and compared against a standard. If it is within acceptable range of the standard, the sensor is stored ready for use. The usual practice for bench checking a sensor involves a CR10X logger and testing equipment. First, the sensor is cleaned and damaged parts are fixed or replaced.

While in the field, the sensors from the three stations can be compared together. A sensor that is not performing properly will deviate from similar sensors on the other systems. Sometimes short-term deviations can be explained by a small-scale weather disturbance, e.g. rainsqualls.

\section{Wind Speed}

After the cups are removed, the wind speed sensor is attached to a tachometer. The shaft is rotated at exact frequencies and the output is compared to the expected speeds. The sensor passes if the speeds are all within $0.2 \mathrm{~m} \mathrm{~s}^{-1}$ of the expected values.

The roll test tests the starting torque of the wind speed sensor. With the cups attached, roll the sensor on a flat, level table. If the cups do not rotate while the sensor body is slowly rolled, the sensor passes this simple test. If necessary, the bearings of a wind speed sensor can be replaced to decrease the starting torque.

\section{Wind Direction}

The vane of a wind direction sensor can be rotated to several known angles and the output checked. When a $180^{\circ}$ screw is installed just below the vane, the output should indicate a south wind $\left(180^{\circ}\right)$. The easiest angles to check are the four cardinal directions: $90^{\circ}, 180^{\circ}, 270^{\circ}$, and $0^{\circ}$ (or $360^{\circ}$ ). If any of these angles is off by more than 3 degrees, the sensor should not be used in the field. A torque wheel can also be used to measure the starting torque of the shaft. The starting torque for the Handar 431 wind direction sensor should be less than $6.5 \mathrm{gm} \cdot \mathrm{cm}$.

\section{Temperature}

A temperature sensor can be compared to an accurate thermometer. If the indicated temperature is $0.5^{\circ} \mathrm{C}$ from the standard, the sensor should not be used in the field. This check against a standard can be done at just one temperature. Since the expected range of ambient air temperature at Bikini Atoll is very narrow $\left(24\right.$ to $34^{\circ} \mathrm{C}$ ) it is not necessary to check the sensor at more than one temperature. The thermistors must not be immersed in water.

\section{Relative Humidity}

The relative humidity sensor is the sensor most likely to deviate from its factory calibration. The thin polymer film over the capacitance element is susceptible to contamination. The relative humidity sensor can be compared to a standard sensor or held over salt solutions providing a known humidity. If the sensor is more than 5\% from the standard, it should not be used.

\section{Solar}

The solar cell can be compared to a recently calibrated pyranometer. A special program has been written for the CR10X to continuously sample the solar cell(s) and the standard(s), and compute 1minute averages. The sensors are co-located and exposed to several hours of full sunlight. The resulting data can be analyzed to verify the factory calibration or create a new calibration factor. Alternatively, there are several companies that will find the calibration factor of any solar cell. The 
Table 3. List of sensors used by the Marshall Islands Program. This inventory was taken in May 2001.

\begin{tabular}{|c|c|c|}
\hline Sensor Type & Number & Serial numbers in inventory \\
\hline Wind Speed & 18 & $\begin{array}{l}112,463,471,652,657,660,667,769,772,790,984,1077,1096,1102,1121,2254, \\
2255,2343\end{array}$ \\
\hline Wind Direction & 18 & $\begin{array}{l}339,465,598,603,604,611,640,704,709,714,722,1048,1050,1171,1809,2191, \\
2192,2233\end{array}$ \\
\hline Temperature & 9 & $108,348,375,407,408,409,667,954,958$ \\
\hline \multicolumn{3}{|l|}{ Temperature and } \\
\hline Relative humidity & 7 & $652,655,662,672,2751,3115, \mathrm{R} 35857$ \\
\hline Solar & 7 & 0881-7603, PY17830, PY2043-8001, PY33682, PY33683, PY722-7609, PY8129 \\
\hline Rain gauge & 13 & $\begin{array}{l}\text { WT-2666, WM-3670, WM-3710, WM-2584, 2170, 405, plus } 7 \text { with unknown } \\
\text { serial numbers }\end{array}$ \\
\hline
\end{tabular}

individual calibration factor will not be applied in the logger program. Rather, a standard calibration factor will be used in the program. The individual calibration factor will be used when the data is post processed for inclusion in the monthly files.

\section{Rain Gauge}

A rain gauge can be calibrated by simply pouring 1-liter of water into its funnel. This operation can be done in the laboratory or in the field. A rain gauge calibration bottle can be used to slowly dribble the water into the rain gauge. One liter of water poured very slowly into the rain gauge will be counted as 1.09 inches of rain. If the indicated rain is less than 0.98 " or greater than $1.20 "( \pm 10 \%)$ the calibration should be repeated. If a value outside the acceptable range persists, the gauge should be replaced. When calibrating a rain gauge in the field, choose a rainless day. Make a note of the station, date and time of the calibrations, and before and after rainfall readings. Remove the calibration data from the post processed data included in the monthly files.

\section{Installation of Sensors}

We have decided to swap sensors only after they exhibit signs of wear or deviation from calibration. The data should be reviewed weekly with emphasis on comparisons between the three stations.

The wind direction sensor is fitted in a sleeve that remains fixed to the crossarm. It is important not to loosen the two Allen screws that hold the sleeve to the crossarm. The sensor is fixed to the sleeve by a single, small, Phillips-head screw.
Before removing the sensor, check the alignment of the vane. Insert in the $180^{\circ}$ screw into the hole under the tail of the vane. When properly installed, this screw will force the sensor into the $180^{\circ}$ position, which indicates wind from the South. With a magnetic compass, and being mindful of the local declination (about $+8^{\circ}$ ), check the alignment of the sleeve. Checking the alignment can also be done with a GPS receiver.

If the sleeve position is correct, the new wind direction sensor can be installed in the sleeve. The sensor reading should be $180^{\circ}$ when the $180^{\circ}$ screw is in place. The crossarm should also be lined up to true North. Check a few other angles after removing the $180^{\circ}$ screw and rotating the vane parallel and perpendicular to the crossarm.

The wind speed and temperature sensors do not require alignment. To remove one of these sensors, simply detach the connector and loosen the two Allen screws. Reverse this process to install the fresh sensor.

The solar cell is mounted on its own crossarm. A specialized mounting bracket holds the solar cell. The bracket has a bubble level to aid in leveling the solar cell. First loosen the hold-down screws, and then adjust the leveling screws until the bubble is centered. Finally, tighten the hold-down screws while keeping the bubble level centered. The crossarm is low enough to provide easy access for service by standing on a 6-foot ladder while the tower is in its final, upright position.

Threaded studs projecting from concrete slabs hold the rain gauges. The funnel/hood can be removed to gain access to the electrical terminal and 
leveling bubble. Most problems with the rain gauges can be traced to debris in the funnel or tipping buckets, and broken or disconnected terminal wires.

\section{Data Recovery}

There are two basic ways to retrieve data from the loggers: via-satellite and on-site. Collecting data via satellite is the routine method of data collection. It involves a desktop PC and an Internet connection to the NOAA Wallops Command and Data Acquisition Station. The on-site method requires a direct connection to the logger.

\section{Via Satellite}

Currently there are two methods for downloading data from NOAA: telnet and webbased. Both methods require the user name (LLL18W) and a password. The DCS web site, http://dcs.noaa.gov/, has a link for telnet access.

Web-based downloads can be made through the URL http:/ / dcs.noaa.gov/default1.asp.

Data downloaded via satellite includes a DAPS message (Table 4) and the DCP data. A typical data string that represents three hours of data from one logger is 293 bytes long, not including the 37-byte DAPS message.

The downloaded data follows the DAPS download message. The data is coded to reduce size. Each number is coded into three characters. Appendix $\mathrm{C}$ includes the FORTRAN source code that converts three characters into the numeric equivalent. For example, the string @_Q is converted to the value 2001.

\section{On Site}

All the data that are in the memory of the logger can be downloaded to a storage module or laptop computer. The 2-Megabyte loggers can hold over three years of data. For this download method, use a keyboard (model CR10KD), and storage module (SM4M) connected with the same blue cable (SC12). Connect the combination to the CS I/O port on the logger. The data on the module is downloaded to a computer running the Windows-based program PC208W. The data file can then be copied to floppy, and sent to LLNL for analysis and archiving.

\section{Monthly Files}

Every month, data from all three stations are compiled into a single Excel workbook. The tables and graphs created in these workbooks should be reviewed for completeness, and crosschecked. Appendix D contains a series of plots of the Bikini meteorological data created for each month from May 2000 through February 2001.

\section{Annual Files}

Selected data from every month are compiled into an Excel workbook representing a summary of the entire year. A series of tables and charts from the year 2000-2001 is shown in Appendix E. The meteorological year for Bikini coincides with the calendar year.

\section{Summary of 2000-2001 Data}

Every year a summary of the experiences with the Bikini meteorological system should be consolidated into a report for distribution within the Marshall Islands Program. Included should be tables of daily and monthly totals of rainfall, reports of missing data, sensor-swap reports, and any other significant data or news pertaining to the system. The following section is a summary report for the period from the installation of the new loggers 
Table 4. Interpretation of the DAPS download message string following this example: CA30022A01131094624G46-4NN030W0000293.

\begin{tabular}{lcll}
\hline Example & Size (bytes) & \multicolumn{1}{c}{ Name of field } & \multicolumn{1}{c}{ Notes } \\
\hline CA3022A & 8 & Address of logger & \\
01 & 2 & Year message was received & 01 is 2001 \\
131 & 3 & Day of year message received & 131 is 11 May for non-Leap Year \\
09 & 2 & Hour message was received & GMT \\
46 & 2 & Minute message was received & \\
24 & 2 & Second message was received & G for Good data; ? for parity error \\
$\mathrm{G}$ & 1 & Status code & Between 44 and 48 is normal \\
46 & 2 & Signal strength & 50 Hz steps; $-4=-200$ Hz; \pm 8 is normal \\
-4 & 2 & Frequency offset & N is Normal \\
$\mathrm{N}$ & 1 & Modulation index & Nis Normal \\
$\mathrm{N}$ & 1 & Data quality & 30 or 28 \\
030 & 3 & Channel message was received & W is GOES West \\
W & 1 & GOES Spacecraft & 00 is normal \\
00 & 2 & Uplink carrier status & \\
00293 & 5 & Length of message in bytes & \\
\hline
\end{tabular}

and transmitters in early May 2000 through the end of April 2001.

\section{Mission and Station Reports}

\section{Spring 2000 Mission}

By 2 May 2000, three new Campbell Scientific CR10X loggers were installed on Bikini Atoll. The existing sensors and towers were combined with new loggers, satellite transmitters and enclosures. The circuitry was simplified, and the logger programs were standardized among the stations. The only sensors not operating at this time were the solar cells, which lacked precision resistors. All the other sensors were swapped with reconditioned sensors. The rain gauges were all checked with a rain gauge calibrator Spring 2001 Mission

Errors in satellite data transmission and timing problems when downloading caused numerous small gaps in the real-time data recovery. Most of these gaps were recovered by Richard Giles in January 2001 by on-site downloading to a storage module. A manual download was also performed during the spring mission. There was a possible 8544 hours of data collection for the period from 9 May 2000 to 30 April 2001. The proportion of data recovered that produced valid wind speed and direction data was 98.8\% for Control Plot, $77.7 \%$ for House 36, and 41.7\% for Eneu.

New solar sensors, complete with the proper precision resistors, were installed in all three stations. House 36 and Control Plot received new solar sensors, while the Eneu station received an old, calibrated and accurate sensor. We manufactured new crossarms to hold the solar sensors. The new crossarms are attached to the towers a few feet above the logger enclosure. This low height ensures that there will be no need to extend the signal wire. Also, alignment of the solar sensor can be done while standing on a 6-foot ladder.

\section{House 36}

An unexplained change in the House 36 logger program starting on 5 August 2000 and ending on 9 September 2000 resulted in a loss of several data channels. During this 34-day period, most of the parameters were not recovered, although wind speed, hourly rainfall, and box temperature were unaffected. On 9 September the logger was reprogrammed. After this date, all channels were collected properly. Unfortunately, the logger was reset at that time, and it was not possible to perform an on-site recovery of the data taken before 9 September. The on-site recovery procedures done in January and April 2001 filled in all the gaps in the House 36 data to yield a complete set of data after 9 September.

\section{Control Plot}

The transmitter on the Control Plot system operated properly from the install date in May 2000 until late in October. The timing and frequency shifted outside the functioning window and data recovery via satellite was interrupted. This transmitter was replaced during the Spring 2001 
mission and sent to Campbell Scientific for warranty repairs. The on-site data recovery successfully retrieved all the data starting in May 2000.

The ambient relative humidity data for the Control Plot is obviously shifted in scale, which can be seen when compared to the House 36 data (see Appendix D). The RH sensor was out of calibration from May 2000 until it was replaced on 4 April 2001. It is hoped that the data taken before 4 April can be adjusted with acceptable precision. Figure 3 illustrates one possible method to make this adjustment. The ambient humidity data taken before and after 4 April shows a roughly linear relationship between the Control Plot and House 36 stations. The data taken before the sensor replacement were adjusted by a linear equation to best fit the post-swap data. This adjustment method may not be appropriate since the House 36 humidity sensor has not been proven to be perfectly accurate. We will perform several procedures during the next field mission to calibrate the $\mathrm{RH}$ sensors.

\section{Eneu}

The base of the Eneu tower was corroded to the point that it was unsafe to climb or tilt the tower to swap the anemometer set. After the Spring 2000 mission, Wayne Olival and his support crew replaced the base. We were able to tilt the tower during the Spring 2001 mission and replace all sensors except the rain gauges.

The Eneu logger inexplicably stopped data transmission via satellite on 29 November 2000. The attempt to recover the lost data with an on-site download was unsuccessful in January 2001. While servicing the Eneu system during the spring mission, we found that the logger program was incorrect and actually set to sit idle. These problems were corrected on 3 April 2001 and the Eneu station is currently working properly.

\section{Historical Rainfall Data}

The Marshall Islands Program has maintained several rain gauges on Bikini Island since July 1985.
The longest and most-complete record comes from the manual gauge located near the Department of Energy (DOE) compound. This gauge is a simple graduated rain collector. Every day at 7 p.m. the gauge is read, and the total daily rain is recorded in a notebook. The rain record from this gauge is complete except for a few missing days in April, May, and July of 1992.

In April 1990, five gauges were installed as part of the automatic weather-monitoring system on Bikini Atoll. Two gauges were part of the Control Plot system, two at House 36, and one on Eneu with a second installed in May 2000.

Monthly totals of rain measured by all six Bikini Atoll rain gauges are listed in Appendix F. The monthly totals are computed from daily values. Data are omitted from the monthly list when there are significant missing daily data. The column on the far right (Bikini Isle average) represents the best estimate for the monthly rainfall for Bikini Island. This column is computed from all valid data from the Bikini Island gauges (Control Plot, House 36, and the Manual gauge). Before May 2000 the Bikini Isle average was computed using monthly data. From May 2000 to present daily totals are used to compute the Bikini Isle average.

The annual summary of the monthly rain data from Appendix F appears in Table 5. The average rainfall computed from the 13 years of Bikini Isle averages (1986 through 1998) is $64.8^{\prime \prime}(164.6 \mathrm{~cm})$. The column in Table 5 of Bikini Isle averages is presented in Figure 4. The asterisks above the bars for the years 1985, 1999, and 2000 indicate that the totals for these years are incomplete.

The average monthly rainfall illustrated in Figure 5 is based on the Bikini Island averages in Appendix F. Table 6 shows the monthly averages for all the rain gauges on Bikini Atoll. Differences among these monthly averages are caused, in large part, by the mixture of months that make up the individual average. The annual average computed from the 


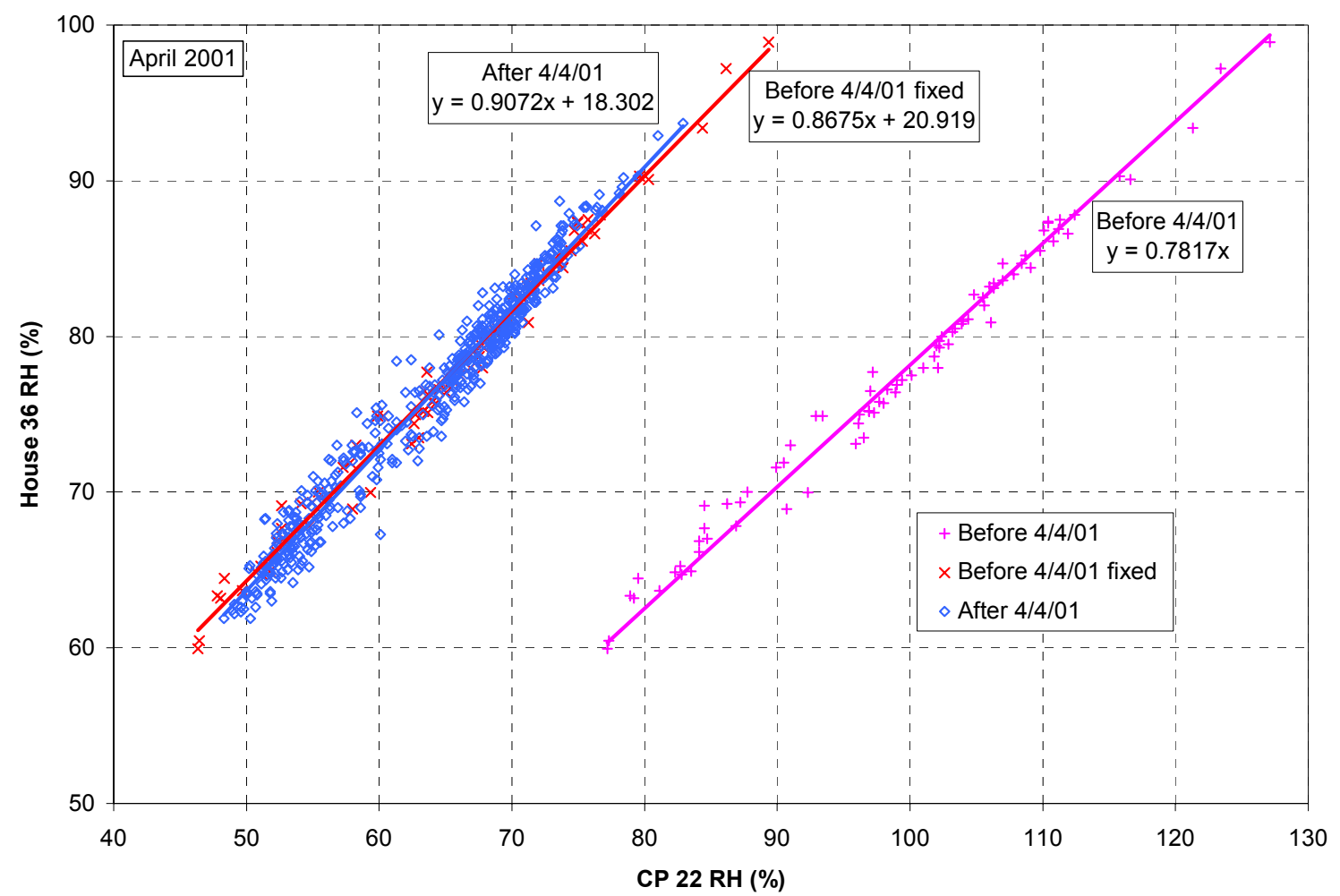

Figure 3. Comparison of relative humidity as measured at the Control Plot and House 36 stations. Least-squares fits are included for the original CP data taken before the sensor swap on 4/4/01, the CP data after the swap, and the adjusted CP data

Table 5. Historical values of the annual total rain (inches) for the Bikini Atoll gauges. Based on all available data from July 1985 through April 2001.

\begin{tabular}{|c|c|c|c|c|c|c|c|c|}
\hline Year & $\mathrm{CP} 1$ & CP 2 & H36 1 & H36 2 & Eneu 1 & Eneu 2 & $\begin{array}{c}\text { Manual } \\
\text { gage }\end{array}$ & $\begin{array}{c}\text { Bikini Isle } \\
\text { average }\end{array}$ \\
\hline 1985 & $33.66^{\mathrm{a}}$ & $\mathrm{n} / \mathrm{a}$ & $\mathrm{n} / \mathrm{a}$ & $\mathrm{n} / \mathrm{a}$ & $\mathrm{n} / \mathrm{a}$ & $\mathrm{n} / \mathrm{a}$ & $33.50^{\mathrm{a}}$ & $33.58^{a}$ \\
\hline 1986 & $15.14^{\mathrm{a}}$ & $\mathrm{n} / \mathrm{a}$ & $\mathrm{n} / \mathrm{a}$ & $\mathrm{n} / \mathrm{a}$ & $\mathrm{n} / \mathrm{a}$ & $\mathrm{n} / \mathrm{a}$ & 82.05 & 79.32 \\
\hline 1987 & $\mathrm{n} / \mathrm{a}$ & $\mathrm{n} / \mathrm{a}$ & $\mathrm{n} / \mathrm{a}$ & $\mathrm{n} / \mathrm{a}$ & $\mathrm{n} / \mathrm{a}$ & $\mathrm{n} / \mathrm{a}$ & 44.98 & 44.98 \\
\hline 1988 & $\mathrm{n} / \mathrm{a}$ & $\mathrm{n} / \mathrm{a}$ & $\mathrm{n} / \mathrm{a}$ & $\mathrm{n} / \mathrm{a}$ & $\mathrm{n} / \mathrm{a}$ & $\mathrm{n} / \mathrm{a}$ & 50.84 & 50.84 \\
\hline 1989 & $\mathrm{n} / \mathrm{a}$ & $\mathrm{n} / \mathrm{a}$ & $\mathrm{n} / \mathrm{a}$ & $\mathrm{n} / \mathrm{a}$ & $\mathrm{n} / \mathrm{a}$ & $\mathrm{n} / \mathrm{a}$ & 71.87 & 71.87 \\
\hline 1990 & $40.46^{\mathrm{a}}$ & $44.47^{a}$ & $76.82^{\mathrm{a}}$ & $81.89^{a}$ & 88.40 & $\mathrm{n} / \mathrm{a}$ & 104.25 & 98.09 \\
\hline 1991 & $57.97^{a}$ & 58.80 & $2.84^{\mathrm{a}}$ & 71.18 & 56.12 & $\mathrm{n} / \mathrm{a}$ & 73.98 & 68.77 \\
\hline 1992 & 54.77 & $37.31^{\mathrm{a}}$ & $36.81^{a}$ & $43.31^{\mathrm{a}}$ & 53.64 & $\mathrm{n} / \mathrm{a}$ & $59.37^{a}$ & 56.62 \\
\hline 1993 & $39.39^{a}$ & $22.87^{a}$ & $28.63^{a}$ & $28.97^{a}$ & $36.54^{\mathrm{a}}$ & $\mathrm{n} / \mathrm{a}$ & 61.11 & 60.78 \\
\hline 1994 & $10.01^{\mathrm{a}}$ & $8.62^{\mathrm{a}}$ & $40.91^{\mathrm{a}}$ & $45.56^{\mathrm{a}}$ & $23.43^{\mathrm{a}}$ & $\mathrm{n} / \mathrm{a}$ & 68.42 & 63.67 \\
\hline 1995 & 52.44 & $40.68^{a}$ & $51.37^{a}$ & 52.32 & $12.82^{\mathrm{a}}$ & $\mathrm{n} / \mathrm{a}$ & 57.78 & 52.55 \\
\hline 1996 & $41.79^{a}$ & $34.50^{\mathrm{a}}$ & $38.43^{a}$ & $42.33^{a}$ & $\mathrm{n} / \mathrm{a}$ & $\mathrm{n} / \mathrm{a}$ & 73.52 & 65.99 \\
\hline 1997 & 87.29 & 73.32 & $68.11^{\mathrm{a}}$ & $91.02^{\mathrm{a}}$ & $\mathrm{n} / \mathrm{a}$ & $\mathrm{n} / \mathrm{a}$ & $\mathrm{n} / \mathrm{a}$ & 84.88 \\
\hline 1998 & $2.11^{\mathrm{a}}$ & $1.86^{\mathrm{a}}$ & $1.31^{\mathrm{a}}$ & $1.75^{\mathrm{a}}$ & $\mathrm{n} / \mathrm{a}$ & $\mathrm{n} / \mathrm{a}$ & 43.74 & 42.62 \\
\hline 1999 & $\mathrm{n} / \mathrm{a}$ & $\mathrm{n} / \mathrm{a}$ & $\mathrm{n} / \mathrm{a}$ & $\mathrm{n} / \mathrm{a}$ & $\mathrm{n} / \mathrm{a}$ & $\mathrm{n} / \mathrm{a}$ & 31.26 & 39.47 \\
\hline 2000 & $43.67^{a}$ & $42.47^{a}$ & $35.45^{\mathrm{a}}$ & $33.77^{a}$ & $25.73^{\mathrm{a}}$ & $26.62^{a}$ & 51.92 & 43.83 \\
\hline
\end{tabular}

${ }^{a}$ Incomplete data. 


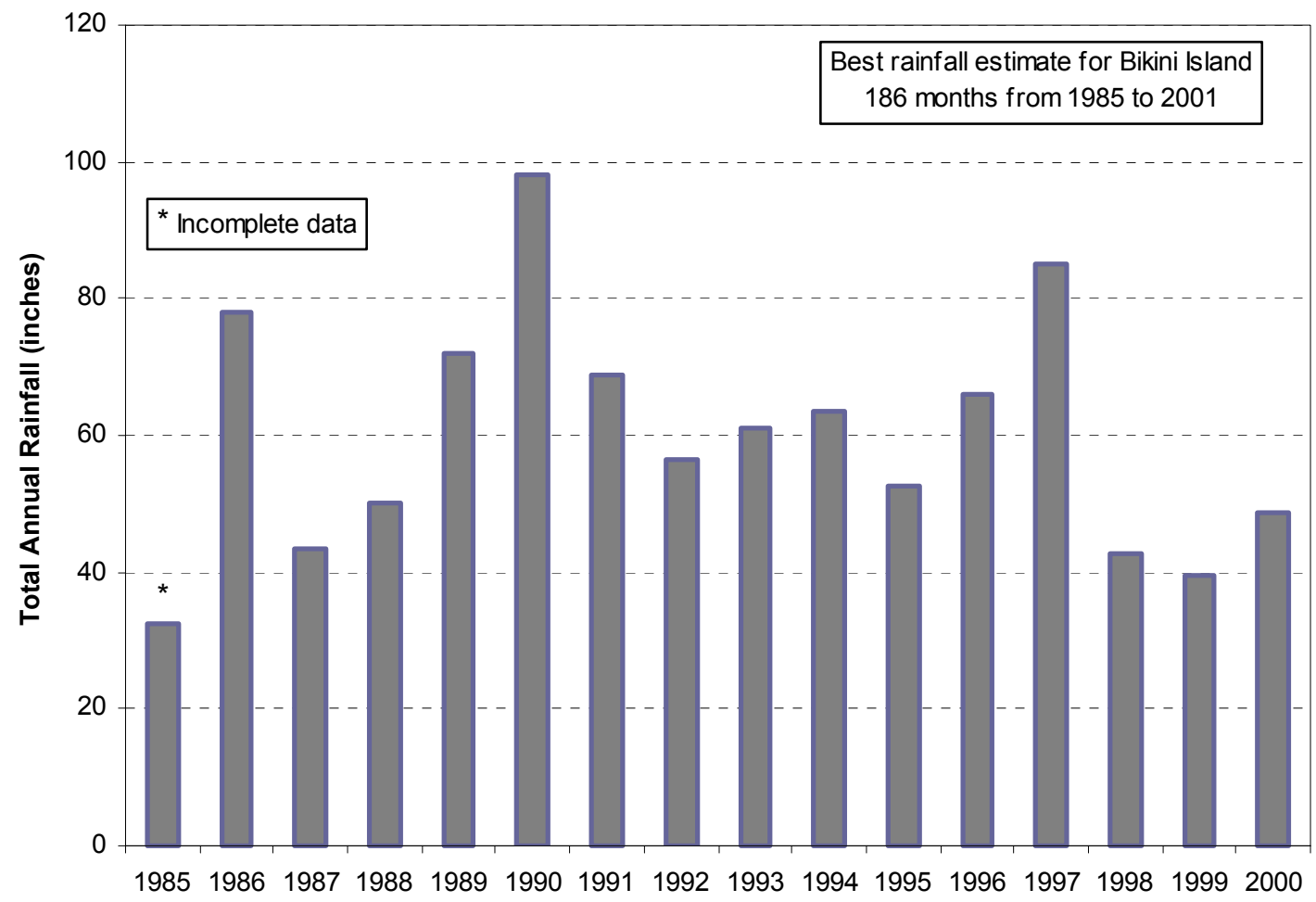

Figure 4. Annual total rainfall for the year 1985 through 2000 from the Bikini Island average.

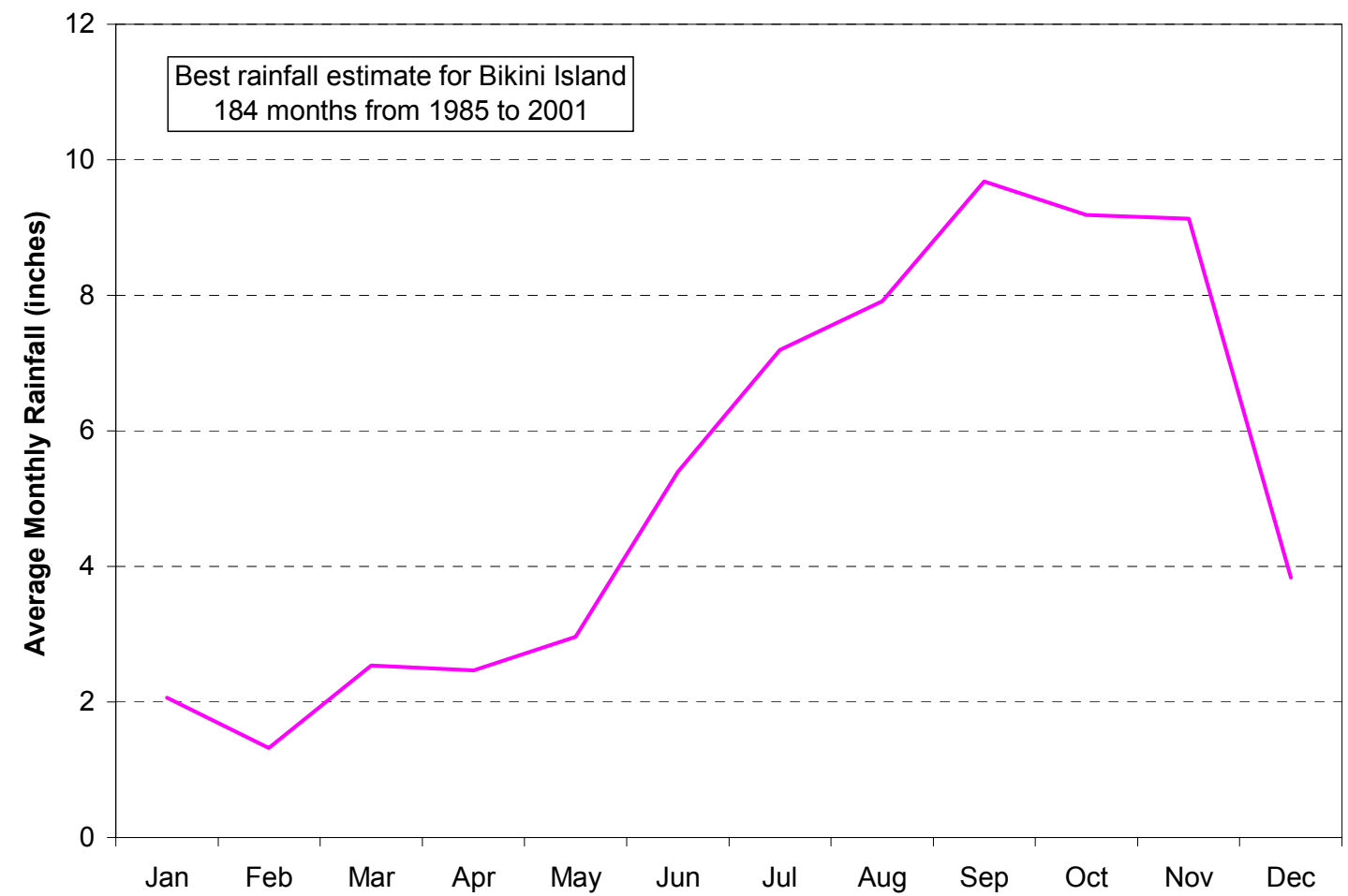

Figure 5. Monthly average of rain based on the best estimate of all Bikini Island data. 
Table 6. Historical values of monthly average rain (inches) for the Bikini Atoll gauges. Based on all available data from July 1985 through April 2001.

\begin{tabular}{lcccccccc}
\hline Month & $\begin{array}{c}\text { CP } \\
\text { South }\end{array}$ & $\begin{array}{c}\text { CP } \\
\text { North }\end{array}$ & $\begin{array}{c}\text { H36 } \\
\text { Plot }\end{array}$ & $\begin{array}{c}\text { H36 } \\
\text { Tower }\end{array}$ & $\begin{array}{c}\text { Eneu } \\
\text { West }\end{array}$ & $\begin{array}{c}\text { Eneu } \\
\text { East }\end{array}$ & $\begin{array}{c}\text { Manual } \\
\text { gauge }\end{array}$ & $\begin{array}{c}\text { Bikini Isle } \\
\text { average }\end{array}$ \\
\hline Jan & 1.67 & 1.22 & 1.29 & 1.51 & 1.74 & n/a & 1.92 & 1.70 \\
Feb & 1.11 & 1.17 & 1.26 & 1.09 & 1.00 & n/a & 1.47 & 1.37 \\
Mar & 2.76 & 2.43 & 3.06 & 2.56 & 3.05 & n/a & 2.33 & 2.66 \\
Apr & 2.45 & 2.35 & 2.74 & 2.77 & 1.86 & 0.18 & 2.27 & 2.30 \\
May & 3.29 & 2.31 & 2.48 & 3.18 & 2.38 & 1.19 & 2.81 & 2.88 \\
Jun & 3.17 & 3.04 & 4.16 & 4.29 & 3.34 & 0.86 & 5.13 & 4.86 \\
Jul & 6.52 & 6.23 & 6.45 & 6.10 & 5.89 & 6.52 & 7.39 & 6.70 \\
Aug & 9.30 & 8.99 & 8.32 & 9.42 & 7.56 & 9.45 & 7.89 & 8.05 \\
Sep & 9.26 & 8.60 & 9.39 & 10.08 & 7.79 & 3.08 & 9.25 & 9.61 \\
Oct & 9.38 & 8.99 & 8.10 & 9.15 & 7.40 & 5.52 & 8.95 & 8.34 \\
Nov & 8.20 & 7.13 & 8.85 & 7.91 & 9.21 & n/a & 9.50 & 8.74 \\
Dec & 2.71 & 3.03 & 3.36 & 3.47 & 3.82 & n/a & 3.78 & 3.57 \\
Annual & 59.8 & 55.5 & 59.5 & 61.5 & 55.0 & n/a & 62.7 & 60.8 \\
Relative to Bikini & $-2 \%$ & $-9 \%$ & $-2 \%$ & $1 \%$ & $-9 \%$ & n/a & $3 \%$ & \\
Island average & & & & & & & &
\end{tabular}

Bikini Island average is 61.1" $(155.2 \mathrm{~cm})$. More data will improve the meaning of these statistics. For instance, the large average from the West gauge on Eneu for the month of November (12.48") is based on just three years of data, 1989-1991. The month of November during those three years featured especially high rainfall.

The data in the line of annual averages in Table 6 are computed from a set of months with complete data from all the Bikini Island gauges: Control Plot, House 36, and the Manual gauge. The last line in Table 6 is the relative difference between the station estimate of annual total rainfall and the Bikini Island annual average. The relative differences may indicate instrument error or a geographic difference in rainfall as measured by the rain gauge stations. The North gauge at the Control Plot station shows a persistent relative deficit of rain. This pattern can also be seen in the monthly traces of cumulative rainfall in Appendix D. It is possible that this gauge was placed in a location that is in the rain shadow of some nearby trees. The Tower gauge on the House 36 station and the Manual gauge consistently have the largest rainfall amounts. There may be a slight gradient of precipitation across Bikini Island with larger amounts of rainfall closer to the lagoon.

\section{Rainfall Since May 2000}

A detailed diagram of cumulative rainfall as measured by the 6 rain gauges is presented in Figure 6. All six traces track each other very well. An exceptional rainfall event occurred in late November 2000 when almost 12" of rain fell in a 10-day period. The largest single day rainfall occurred on 8 July 2000 when about 5" was measured by the Bikini Island gauges. Although the Eneu gauge detected just 3.5" at that time, a rainfall event on 6 August of about 4.4" brought the Eneu seasonal total close to the Bikini Island values. The average total rainfall for all 6 gauges was 47.5" during this 360-day period. Despite differences in locations, exposures, instrument bias, and rough adjustments, 4 of the 6 gauges were within $1 \%$ of this average.

The rainfall record from the Control Plot station is complete during the period in Figure 6. The total rainfall as measured by the two Control Plot gauges was 48.62 and $47.30 "$, respectively. The small difference of just $2.8 \%$ is within the accuracy specifications especially when we consider that some of this difference may come from a variation in exposure.

The House 36 data recovery was intermittent from 5 August through 10 September 2000. 


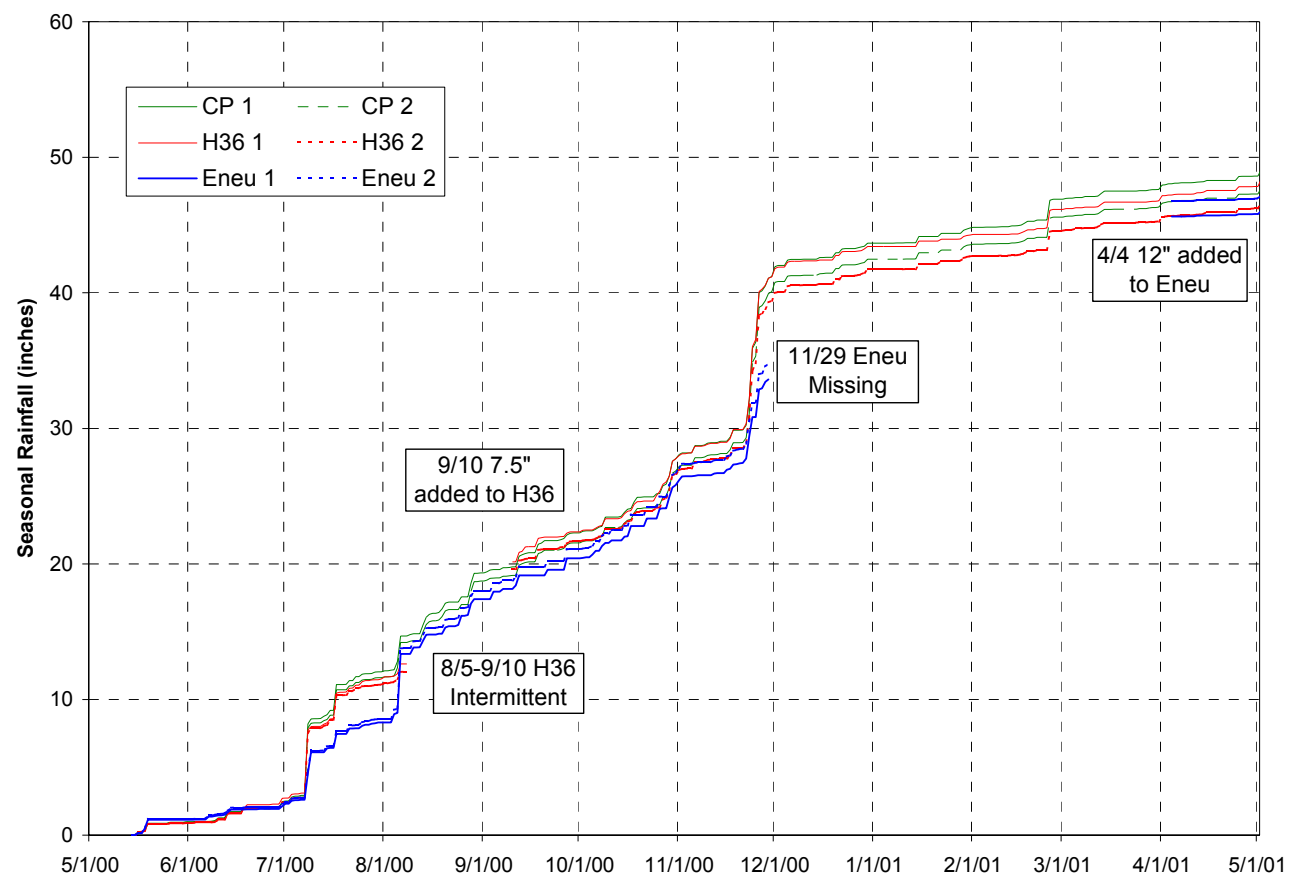

Figure 6. Cumulative daily values of rainfall for the 6 rain gauges on Bikini Atoll for the period starting 6 May 2000 through 30 April 2001.

The missing cumulative rainfall channels complicate this problem. The House 36 data is complete after 10 September. We added $7.5^{\prime \prime}$ to the data from both House 36 gauges to bring the total rainfall close to the Control Plot values. We believe this is a reasonable estimate for rainfall through the gap in data.

The Eneu data was interrupted from 29 November 2000 to 4 April 2001. It is estimated that 12 " of rain fell on Eneu Island during the extended period of missing data. Before this period, the Eneu data features small gaps caused by errors in satellite transmission. The small gaps do not affect the accuracy of the cumulative rainfall data, and the daily total rainfall can be reasonably reconstructed from these data.

\section{Wind Speed}

Although the size of the data sets from the three stations is different, the frequency of wind speed computed from all available data (Figure 7) shows a persistent pattern. See also monthly wind speed plots in Appendix D. The typical pattern reflects the density of the trees and the proximity of trees to the station. The lowest wind speed is typically from the Control Plot's station, the highest from House 36. For instance, $26 \%$ of the Control Plot winds are class 2 and less (WS $<3 \mathrm{~ms}^{-1}$ ), Eneu is $40 \%$, and House 36 is $70 \%$. The cumulative frequencies of wind speed are also at the bottom of the three tables in Appendix G.

\section{Monthly Average Wind Speed}

Using all available data, the average wind speed was computed for every month from May 2000 to April 2001. The time series of the monthly averages (Figure 8) reflects the differences in exposure among the 3 sites. The Control Plot speeds are, on average, 1 $\mathrm{ms}^{-1}$ less than the House 36 and Eneu speeds.

\section{Monthly Average Air Temperature}

The monthly average air temperatures (Figure 9) show a slight, but definite, seasonal variation. The averages were computed from all available 


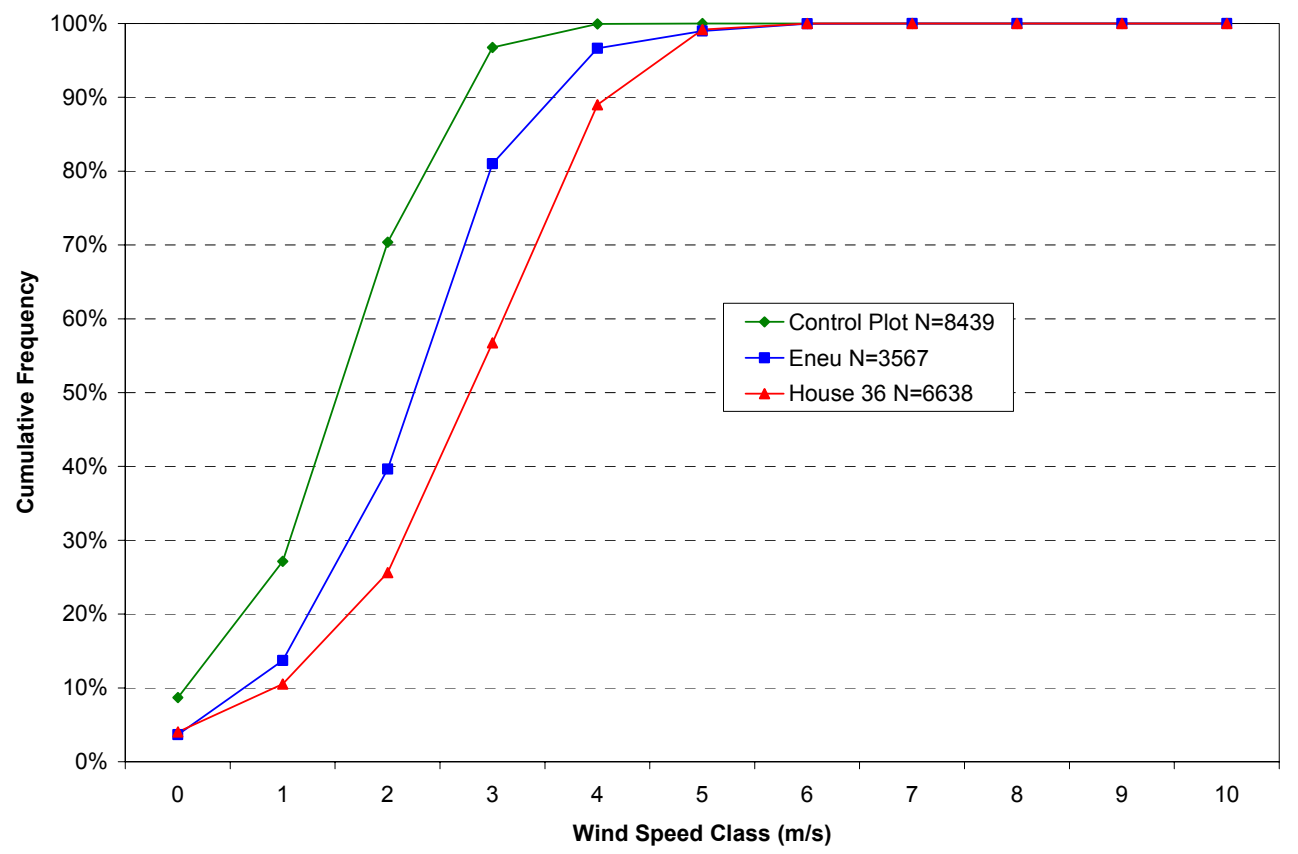

Figure 7. Histogram of cumulative frequency of wind speed class using all available data from May 2000 through April 2001. The classes are determined by removing the fractional portion of the wind speed (i.e., WS=1.5, Class=1).

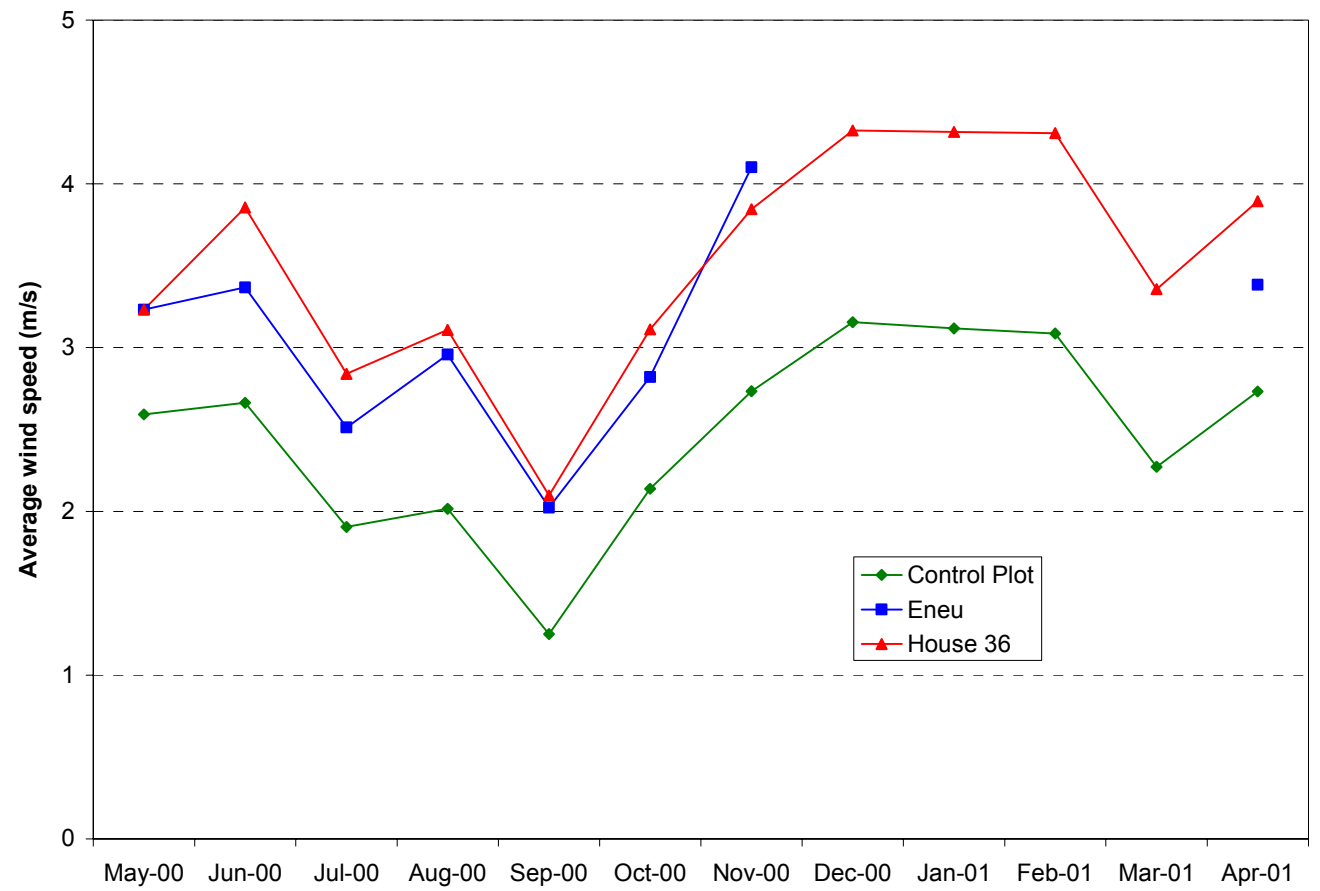

Figure 8. The monthly average wind speed from three Bikini Atoll stations. 


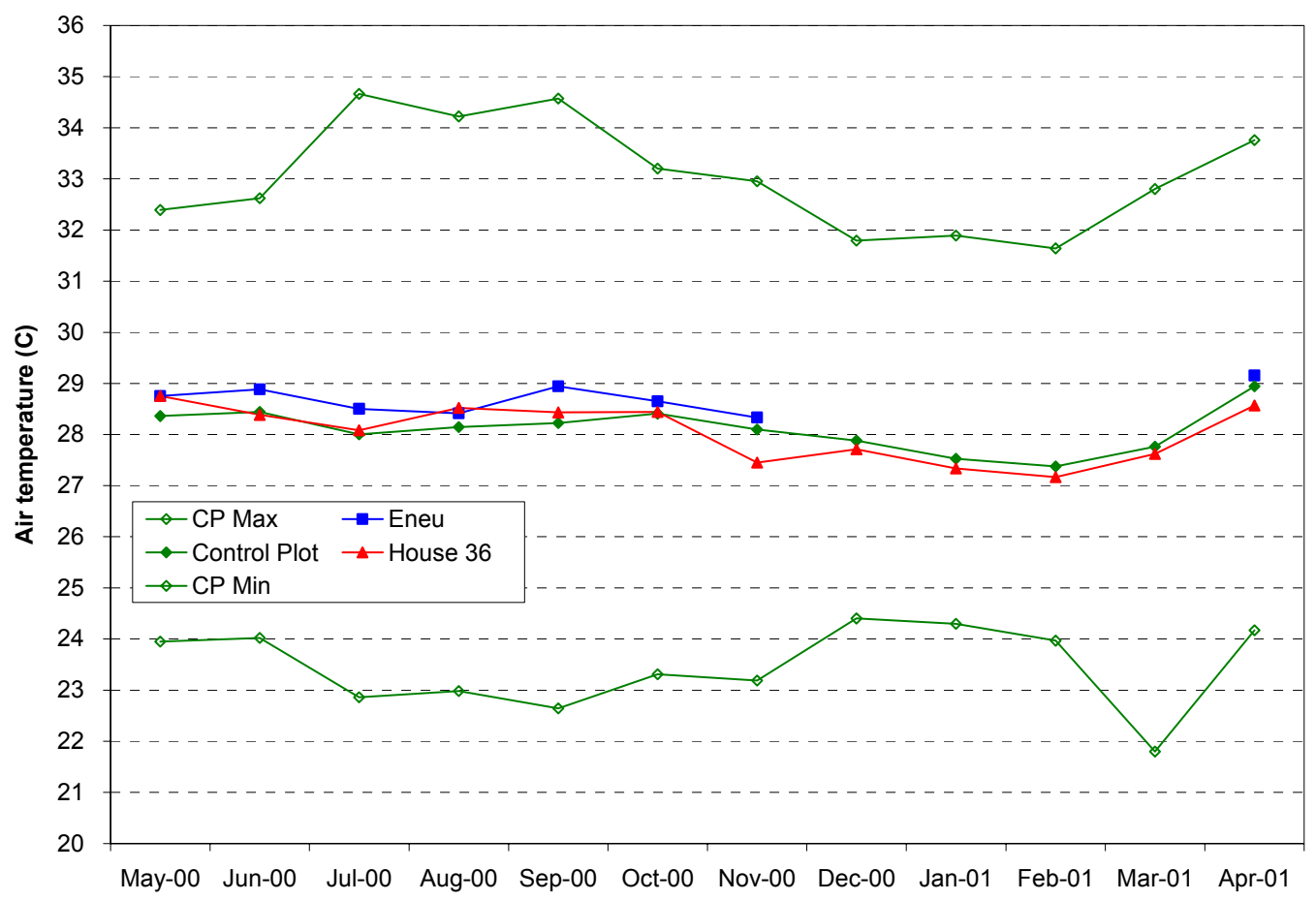

Figure 9. The monthly average air temperature from three Bikini Atoll stations, and the monthly maximum and minimum temperature from the Control Plot station.

hourly data. Again, the most complete data set comes from the Control Plot station so it should be viewed as the most reliable representation of air temperature. Some of the variation in the temperature from the other stations comes from the small differences in ventilation, instrument error, or incompleteness in the data set. For example, the Eneu station data set for the months of September, October, and November, in particular, have a large number of missing values.

The range of temperatures also shows a slight but detectable seasonal pattern. The difference between highest and lowest temperatures was $12^{\circ} \mathrm{C}$ in late summer and less than $8^{\circ} \mathrm{C}$ in the winter. This small amplitude cycle may be caused by the seasonal change in rainfall, cloud cover, or wind speed.
The slight decrease in speed during the summer may cause less vertical mixing, an increase in temperature at the inside the solar shield, and larger diurnal change of temperature.

\section{Annual Windrose}

A complete set of wind rose tables and diagrams appear in Appendix G. The roses show differences between the Control Plot and House 36 wind directions that were caused by instrument error in the House 36 wind direction sensor, and possibly slight misalignment at one or both sites. The Eneu windroses feature winds that are rotated towards north compared with Bikini Island stations. 


\section{Summary}

This document describes in general terms the monitoring systems that collect meteorological data on Bikini Atoll. Included is a complete set of monthly time series of selected hourly data from the three current stations. Tables of daily rainfall from 14 May
2000 to present are included as well as historical totals of monthly rainfall.

This document is the first of a series of annual reports of the Marshall Islands meteorological systems. Future reports will describe significant changes in instrumentation and procedures.

\section{Acknowledgment}

The continuing scientific program on Bikini Atoll is made possible through the efforts of Lance Yamaguchi and his staff from Bechtel Nevada who provide all the logistics support for the program. We would especially like to thank Kenny Selk, Richard Giles, Wayne Olival, Jaspar
Riklon, and Mat Aiseia for helping construct and maintain the meteorological stations. This work was performed under the auspices of the U.S. Department of Energy by the University of California, Lawrence Livermore National Laboratory under Contract No. W-7405-Eng-48.

\section{References}

EPA (1990), Quality Assurance Handbook for Air Pollution Measurement Systems, Volume IV-Meteorological Measurements, EPA-600/4-90/003, U.S. Environmental Protection Agency, Office of Research and Development, Research Triangle Park, NC. 

Appendix A

Wiring Diagrams 
Anemometer crossarm cable

\begin{tabular}{lrlllr} 
Sensor & \multicolumn{2}{c}{540 connector } & Function & CR10X \\
WD A & brown & B & +1 v reference & E3 \\
\hline WD B & black & D & Signal ground & G \\
\hline WD C & red & C & WD signal & SE6 \\
\hline & & & & \\
WS D & blue & E & +12 v supply & $12 \mathrm{~V}$ \\
\hline WS E & black & D & Signal ground & G \\
\hline WS F & white & F & WS Pulses & NVW & P1 \\
\hline & & & & &
\end{tabular}

T/RH cable

Sensor 540 connector Function CR10X

$\begin{array}{llll}\text { A white } & \mathrm{F} & +12 \mathrm{~V} \text { supply } & 12 \mathrm{~V}\end{array}$

$\begin{array}{lllll}\text { B } & \text { green } & \text { D } & \text { Signal ground }\end{array}$

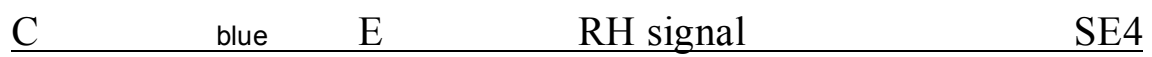

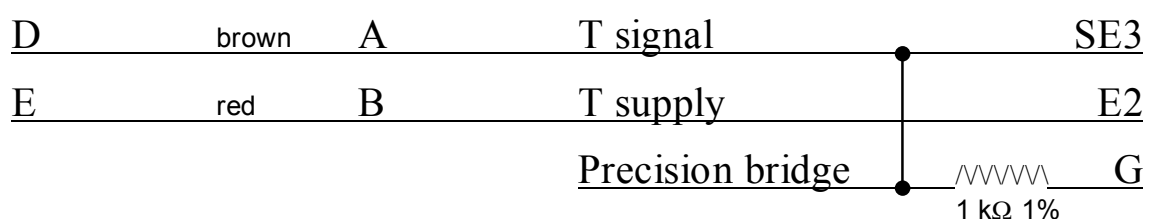

Rain gauge cable

Sensor

Function

CR10X

A

+5 v supply

$5 \mathrm{~V}$

B

Signal

P6 or P7

Note 1: The terminals on the rain gauge are unmarked.

Note 2: Use P6 for gauge \#1, P7 for gauge \#2.

Solar cell cable

\begin{tabular}{lll} 
Sensor & Function & CR10X \\
Center & Ground & AG \\
Shield & Signal & mrm SE7 \\
\hline
\end{tabular}


Appendix B

\section{Logger Programs}

Eneu B-2

House 36 B-5

Control Plot B-8 


\section{Program for Eneu}

; $\{\mathrm{CR} 10 \mathrm{X}\}$

; All current sensors: WD, WS, Rain, T/RH, Solar

; Program for Eneu

; 8 Apr 2001 Frank Gouveia

*Table 1 Program

01: 10 Execution Interval (seconds)

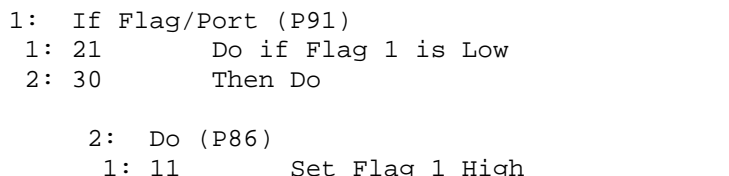

3: Automatic setup of TGT1 (P123)

1: 12 Address

2: 10 Address

3: 3 Address

4: 1 Address

5: 1 Address

$6: 3$ Address

7: 10 Address

8: 6 Address

9: 28 Assigned Uplink Channel

10: 0 Random Uplink Channel

11: 0 Self-timed Interval Days

12: 3 Self-timed Interval Hours

13: 0 Self-timed Interval Minutes

14: 0 Self-timed Interval Seconds

15: 0 Random Interval Hours

16: 0 Random Interval Minutes

17: 0 Random Interval Seconds

18: 1 Initial Self-timed Hours

19: 50 Initial Self-timed Minutes

20: 0 Initial Self-timed Seconds

21: 0 One Minute Window

22: 0 Short Preamble

23: 1 Self-Timed Buffer

; Identifier for Eneu is 31

4: $\quad \mathrm{Z}=\mathrm{F} \quad(\mathrm{P} 30)$

1: $31 \quad \mathrm{~F}$

2: 0 Exponent of 10

3: 1 Z LoC [ Station]

5: $\quad \mathrm{Z}=\mathrm{X}+\mathrm{F} \quad(\mathrm{P} 34)$

1: $1 \quad X$ Loc [ Station

2: $0.11 \quad \mathrm{~F}$

3: 19 Z LOC [ WindID ]

6: $\quad \mathrm{Z}=\mathrm{X}+\mathrm{F} \quad(\mathrm{P} 34)$

1:1 $1 \quad X$ Loc [ Station]

2: $0.15 \quad \mathrm{~F}$

3: 20 Z Loc [ RainID]

7: $\quad \mathrm{Z}=\mathrm{X}+\mathrm{F} \quad(\mathrm{P} 34)$

1: 1 X Loc [ Station ]

2: $0.05 \quad F$

3: 21 Z LOC [ DRainID ]

8: $\quad \mathrm{Z}=\mathrm{X}+\mathrm{F} \quad(\mathrm{P} 34)$

$1: 1 \quad \mathrm{X}$ Loc [ Station ]

2: $0.16 \quad \mathrm{~F}$

3:22 Z Loc [ TempID ]

9: $\quad \mathrm{Z}=\mathrm{X}+\mathrm{F} \quad(\mathrm{P} 34)$

1: $1 \quad X$ Loc [ Station]

2: $0.01 \quad \mathrm{~F}$

3: 18 Z LOC [ BoxID ]

10: End (P95)

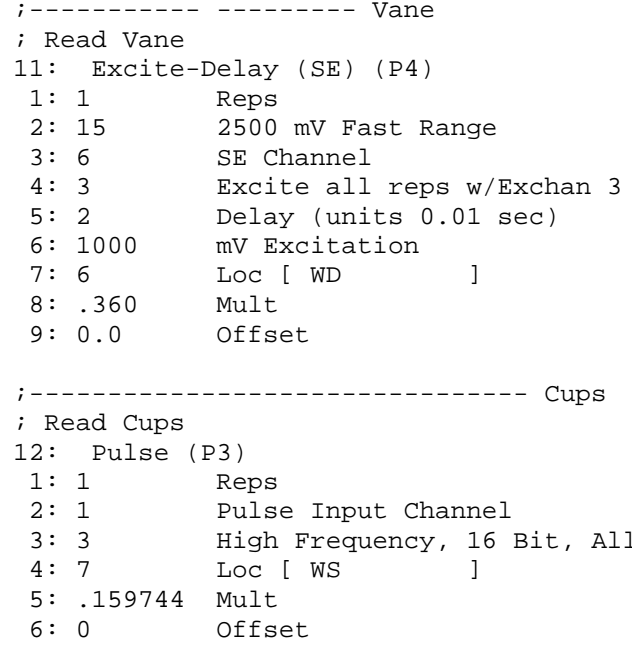

---------------------------- Rain

; Read CP6 for rain gauge, $0.01 "$ per tip 13: Pulse (P3)

1: 1 Reps

2: 6 Pulse Input Channel

3: 2 Switch Closure, All Counts

4: 8 Loc [ Rain1_inc]

5:.01 Mult

6:0 Offset

; Add reading to tota

14: $\quad \mathrm{Z}=\mathrm{X}+\mathrm{Y} \quad(\mathrm{P} 33)$

1: $8 \quad X$ Loc [ Rain1_inc]

2: $10 \quad Y$ LoC [ Rain1

3: 10 Z Loc [ Rain1 ]

; Read CP7 for rain gauge, $0.01 "$ per tip 15: Pulse (P3)

1: 1 Reps

2: 7 Control port 7

3: 2 Switch Closure, All Counts

4:9 Loc [ Rain2_inc]

5:.01 Mult

$6: 0.0$ Offset

; Add reading to total

16: $\quad \mathrm{Z}=\mathrm{X}+\mathrm{Y} \quad(\mathrm{P} 33)$

1:9 $\mathrm{X}$ Loc [Rain2 inc]

2: 11 Y LoC [ Rain2

3: 11 Z LoC [ Rain2

;-------------------------------- RH

; Read the RH voltage $(0-1 \mathrm{v}=0-100 \%)$

17: Volt (SE) (P1)

$1: 1 \quad$ Reps

2: $5 \quad 2500 \mathrm{mV}$ Slow Range

3: 4 SE Channel

4: 13 LOC [ RH

5: $0.1 \quad$ Mult

6: 0 Offset

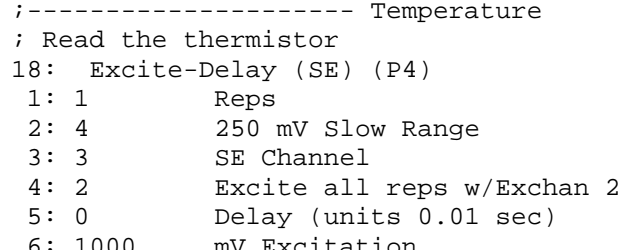




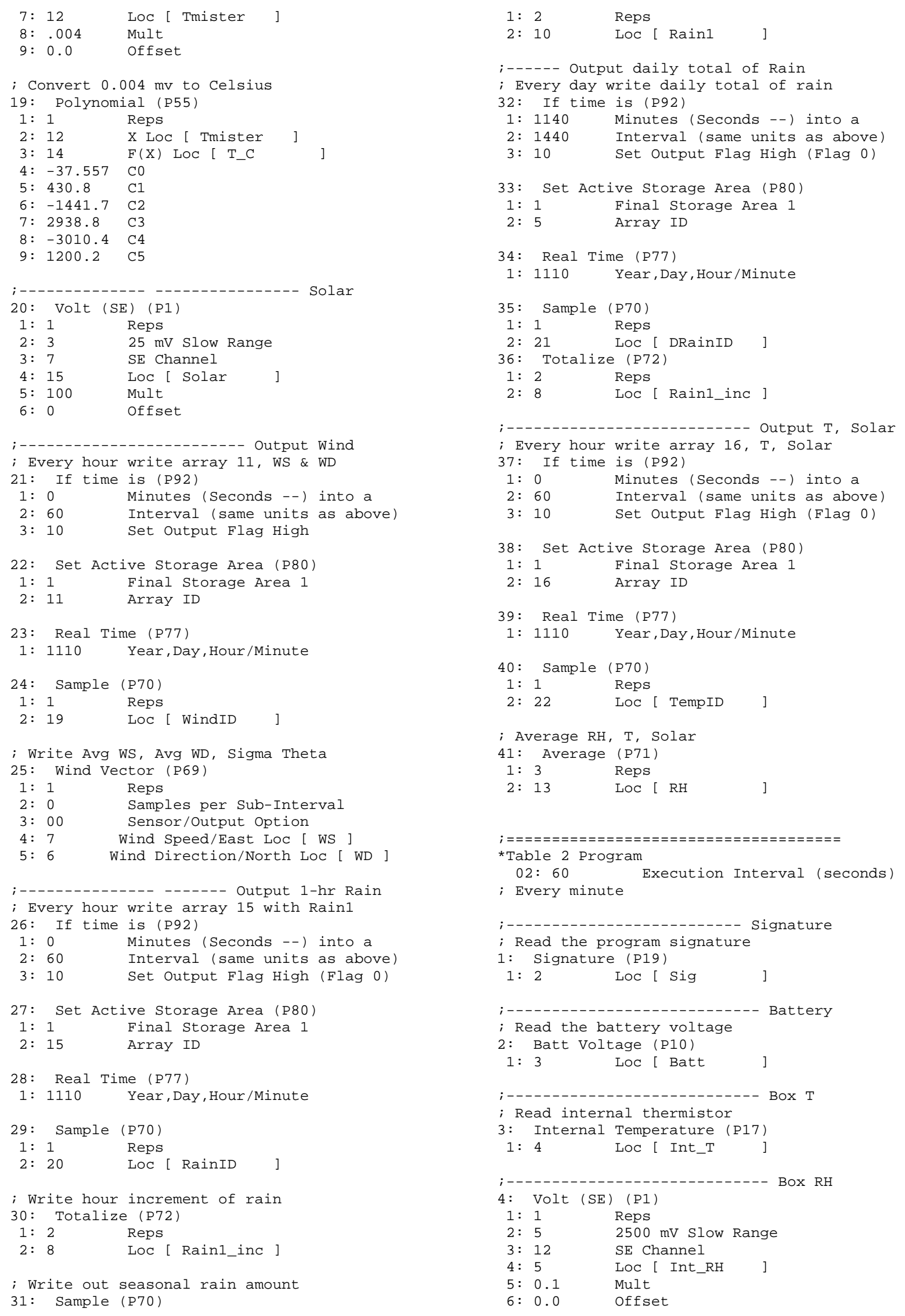



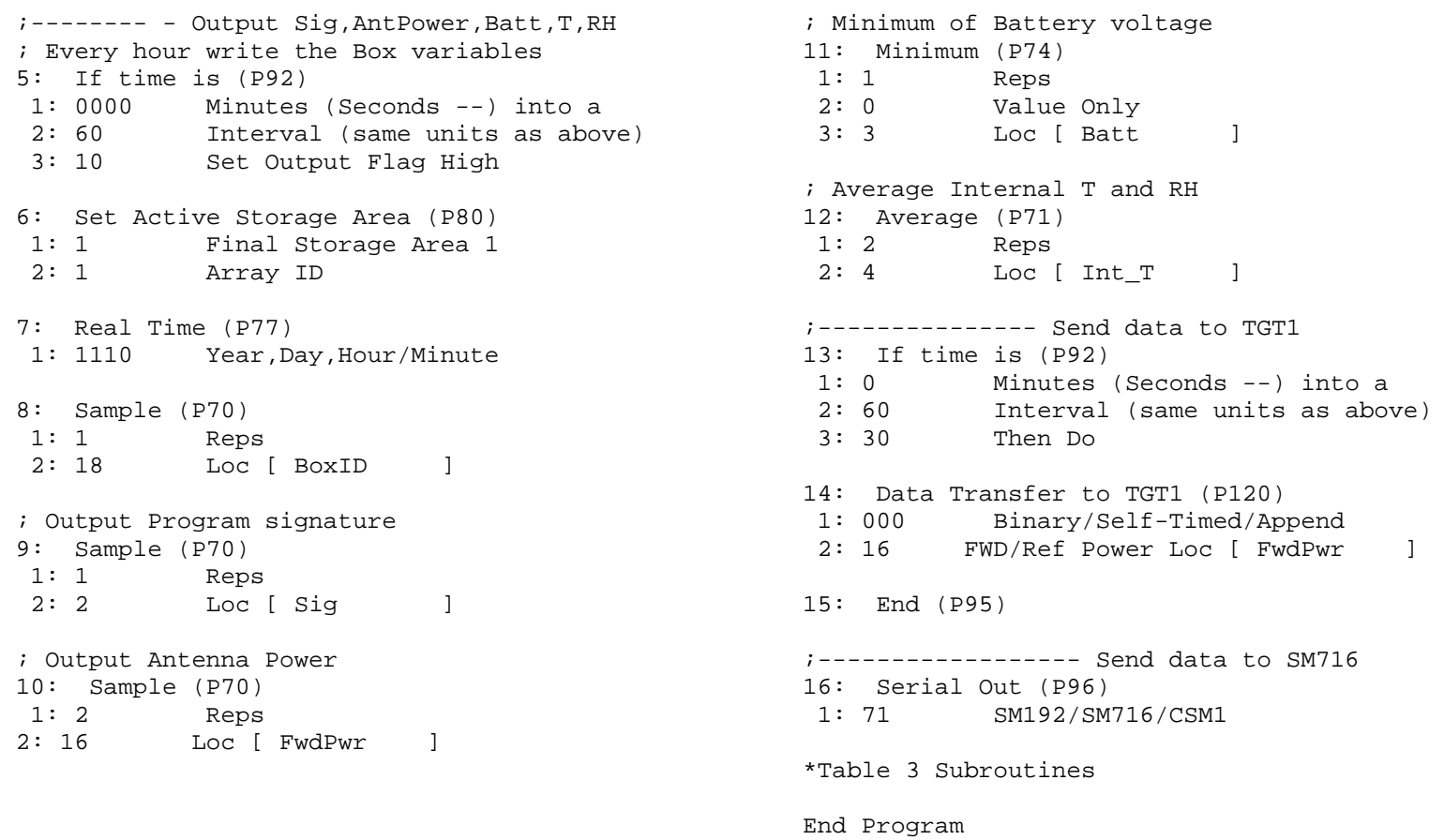


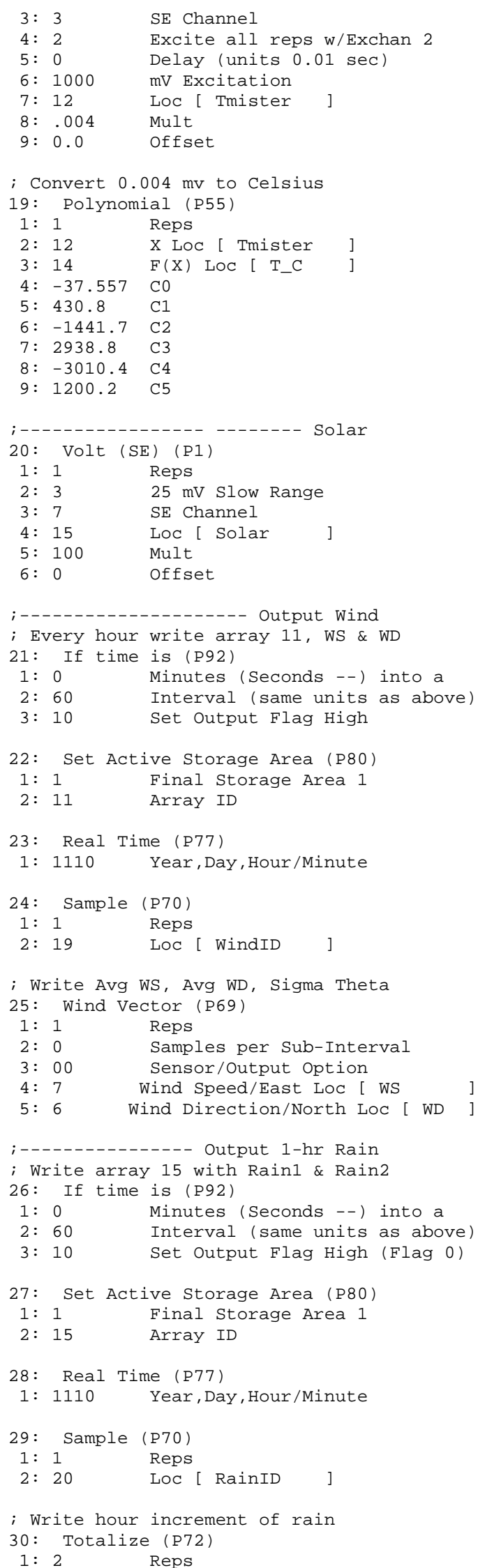




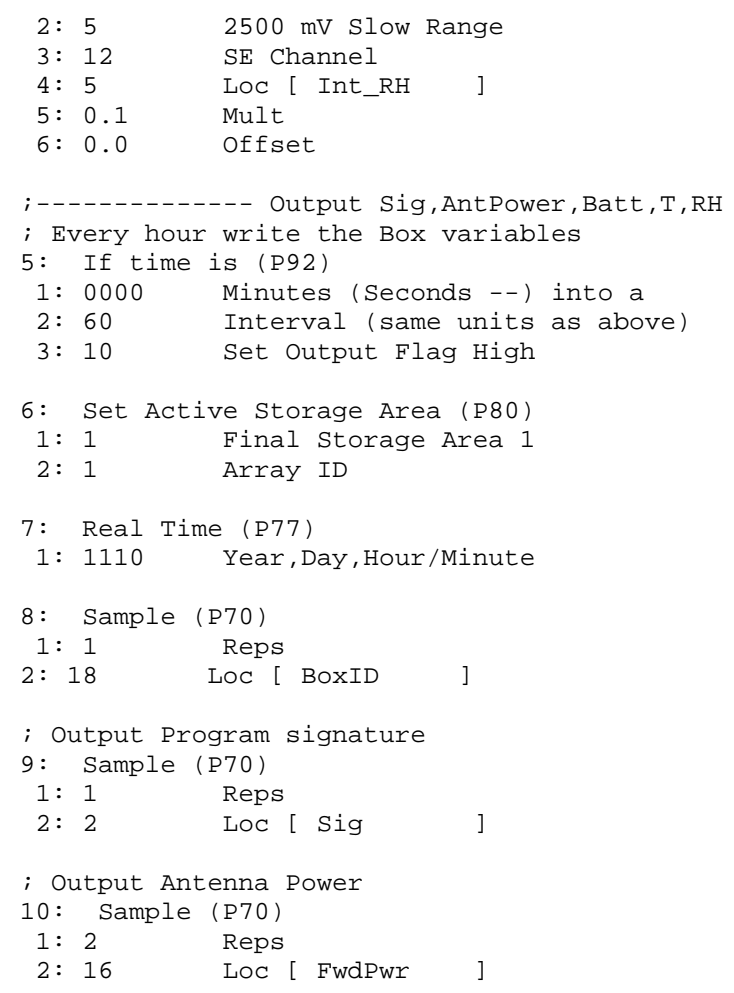

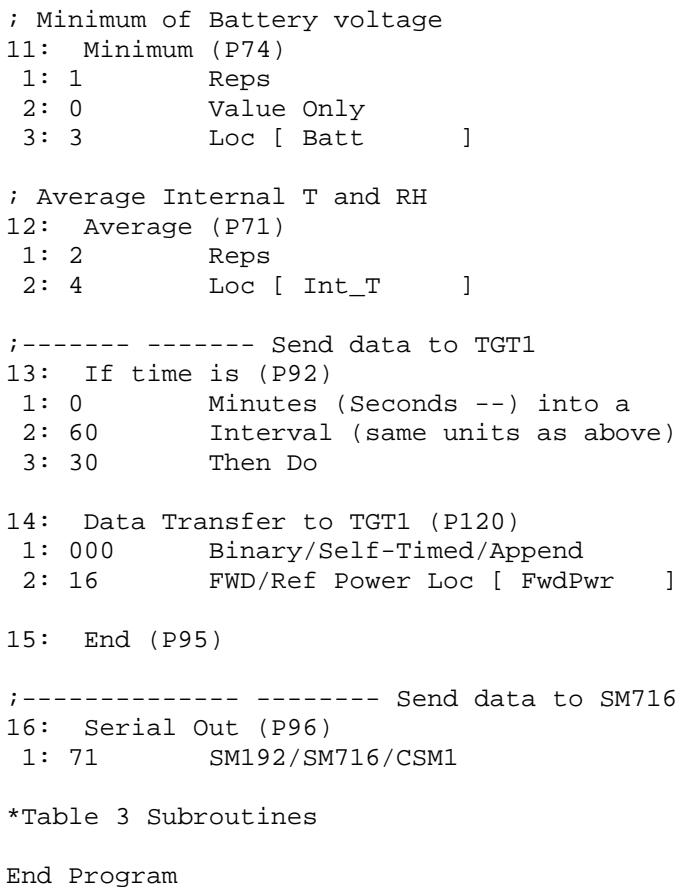




\section{Program for Control Plot}

; $\{\mathrm{CR} 10 \mathrm{X}\}$

; All sensors: WD, WS, 2 Rain, T/RH, Solar

; Program for Control Plot

; 3 Apr 2001 Frank Gouveia

*Table 1 Program

01: 10 Execution Interval (seconds)

1: If Flag/Port (P91)

$\begin{array}{ll}\text { 1: } 21 & \text { Do if Flag } 1 \text { is Low } \\ \text { 2: } 30 & \text { Then Do }\end{array}$

2: Do (P86)

1: 11 Set Flag 1 High

3: Automatic setup of TGT1 (P123)

1: 12 Address

2: $10 \quad$ Address

3: 3 Address

4: 0 Address

5: 0 Address

$6: 2 \quad$ Address

7: 2 Address

8: $10 \quad$ Address

9: 30 Assigned Uplink Channel

10: 0 Random Uplink Channel

11: 0 Self-timed Interval Days

12: 3 Self-timed Interval Hours

13: 0 Self-timed Interval Minutes

14: 0 Self-timed Interval Seconds

15: 0 Random Interval Hours

16: 0 Random Interval Minutes

17: 0 Random Interval Seconds

18: 0 Initial Self-timed Hours

19: 46 Initial Self-timed Minutes

20: 0 Initial Self-timed Seconds

21: 0 One Minute Window

22: 0 Short Preamble

23: 1 Self-Timed Buffer

; Identifier for Control Plot is 22

4: $\quad \mathrm{Z}=\mathrm{F} \quad(\mathrm{P} 30)$

1:22 $\mathrm{E}$

2: $0 \quad$ Exponent of 10

3: 1 Z Loc [ Station ]

5: $\quad \mathrm{Z}=\mathrm{X}+\mathrm{F} \quad(\mathrm{P} 34)$

1:1 1 L Loc [ Station]

2: $0.11 \quad \mathrm{~F}$

3: 19 Z Loc [WindID ]

6: $\quad Z=X+F \quad(P 34)$

1: 1 X Loc [ Station]

2: $0.15 \quad \mathrm{~F}$

3: 20 Z Loc [ RainID ]

7: $\quad \mathrm{Z}=\mathrm{X}+\mathrm{F} \quad(\mathrm{P} 34)$

$\begin{array}{lc}1: 1 & X \text { LoC [ Station ] } \\ 2: 0.05 \quad F\end{array}$

3: 21 Z Loc [ DRainID]

8: $\quad \mathrm{Z}=\mathrm{X}+\mathrm{F} \quad(\mathrm{P} 34)$

1: 1 X Loc [ Station]

2: $0.16 \quad \mathrm{~F}$

3:22 Z Loc [ TempID ]

9: $\quad \mathrm{Z}=\mathrm{X}+\mathrm{F} \quad(\mathrm{P} 34)$

$\begin{array}{llll}1: & 1 & X \text { Loc }[\text { Station ] } \\ 2: & 0.01 & F & \\ 3: & 18 & \text { Z LOC }[\text { BoxID }\end{array}$

10: End (P95)

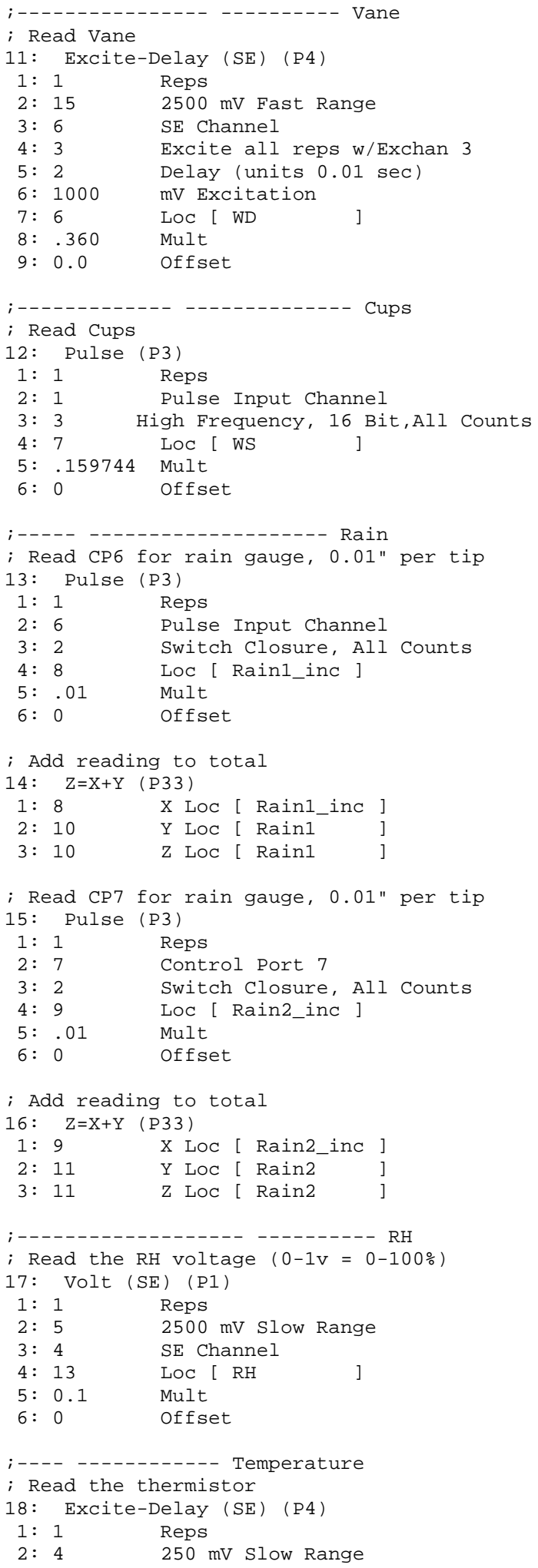



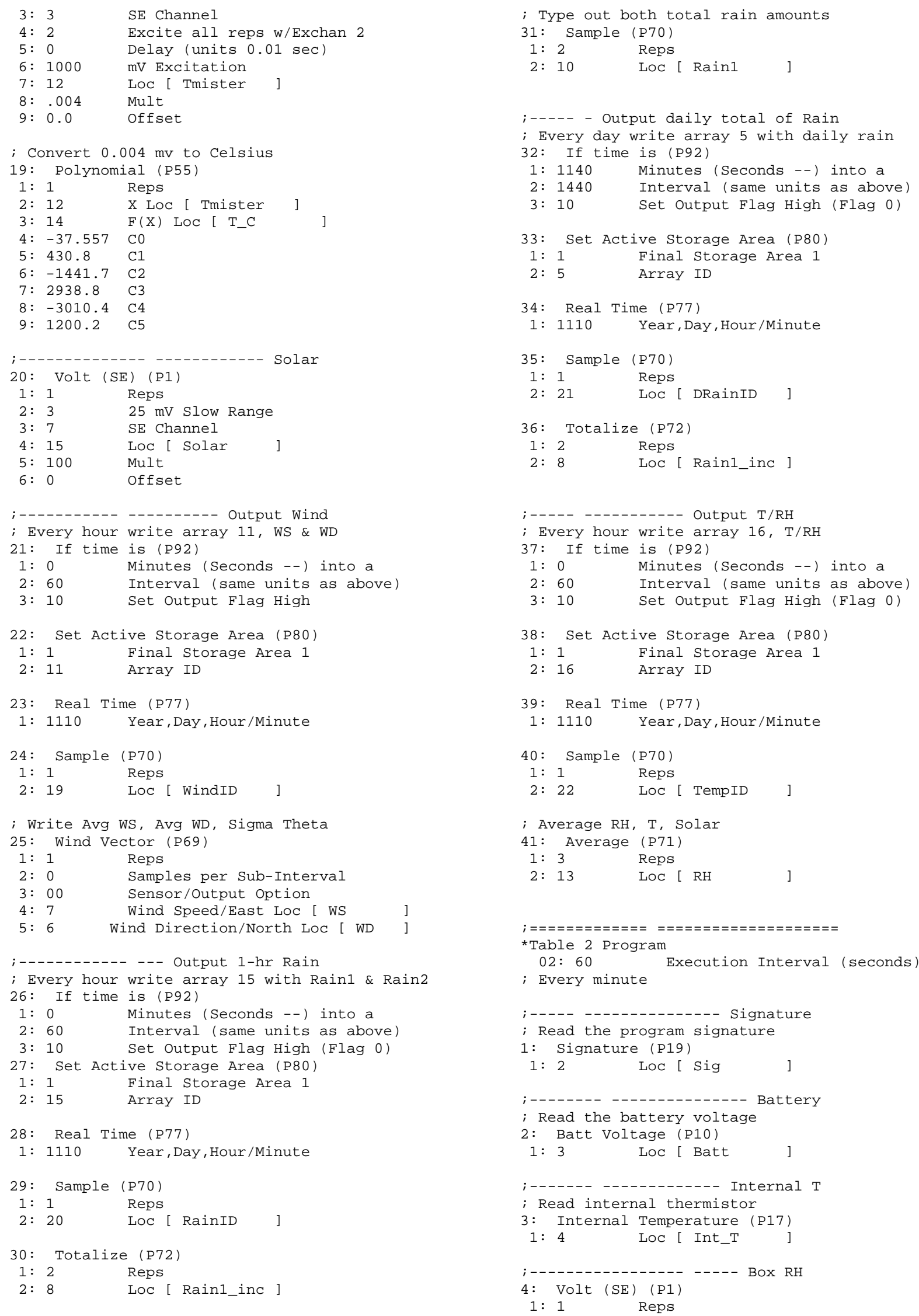


$\begin{array}{ll}2: 5 & 2500 \mathrm{mV} \text { Slow Range } \\ 3: 12 & \text { SE Channel } \\ 4: 5 & \text { Loc [ Int_RH ] } \\ 5: 0.1 & \text { Mult } \\ 6: 0.0 & \text { Offset }\end{array}$

;----------- Output Sig, AntPower, Batt, T, RH

; Every hour write the Box variables

5: If time is (P92)

1: 0000 Minutes (Seconds --) into a

2: 60 Interval (same units as above)

3: 10 Set Output Flag High

6: Set Active Storage Area (P80)

1: 1 Final Storage Area 1

2: 1 Array ID

7: Real Time (P77)

1: 1110 Year,Day, Hour/Minute

8: Sample (P70)

1: 1 Reps

2: 18 LOC [ BOxID]

; Output Program signature

9: Sample (P70)

1: 1 Reps

2:2 LoC [ Sig ]

; Output Antenna Power

10: Sample (P70)

$1: 2$ Reps

2: 16 Loc [ FwdPwr ]

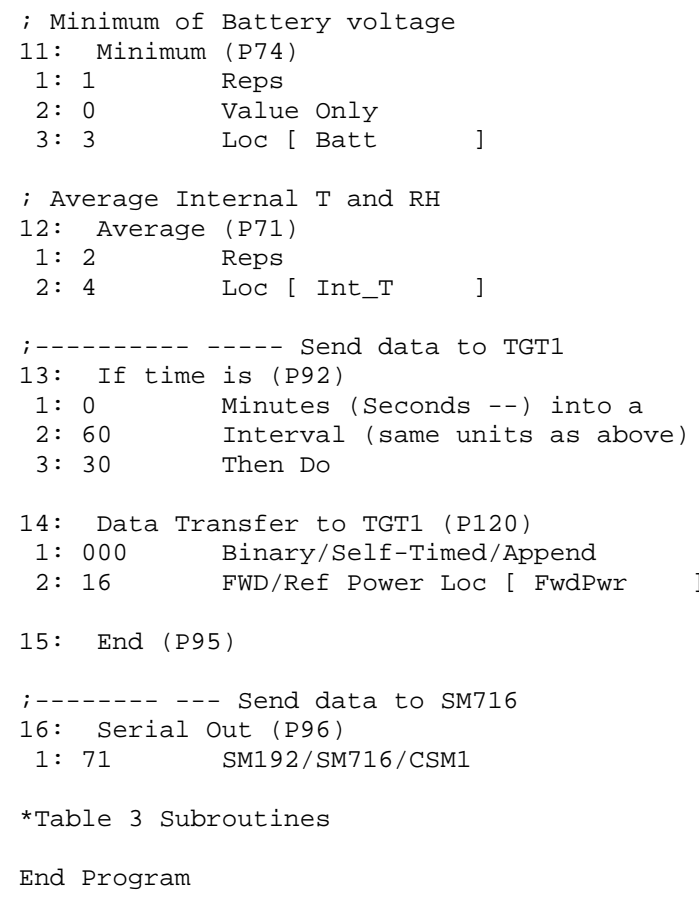


Appendix C

FORTRAN code to interpret 3-character data 
The following FORTRAN subroutine, named CONVERT, is used to interpret three sequential characters as a numeric value.

There are 64 valid characters, ASCII value $63(?)$ through ASCII value $126(\sim)$

? @ABCDEFGHIJKLMNOPQRSTUVWXYZ [ \]^_`abcdefghijklmnopqrstuvwXyz $\{\mid\} \sim$

The IAND function returns the logical product of the two arguments. In other words, the result of the IAND function is a bit-by-bit comparison of the two arguments. The $i$ th bit of the result is set to 1 only if the $i$ th bits of both arguments is 1 .

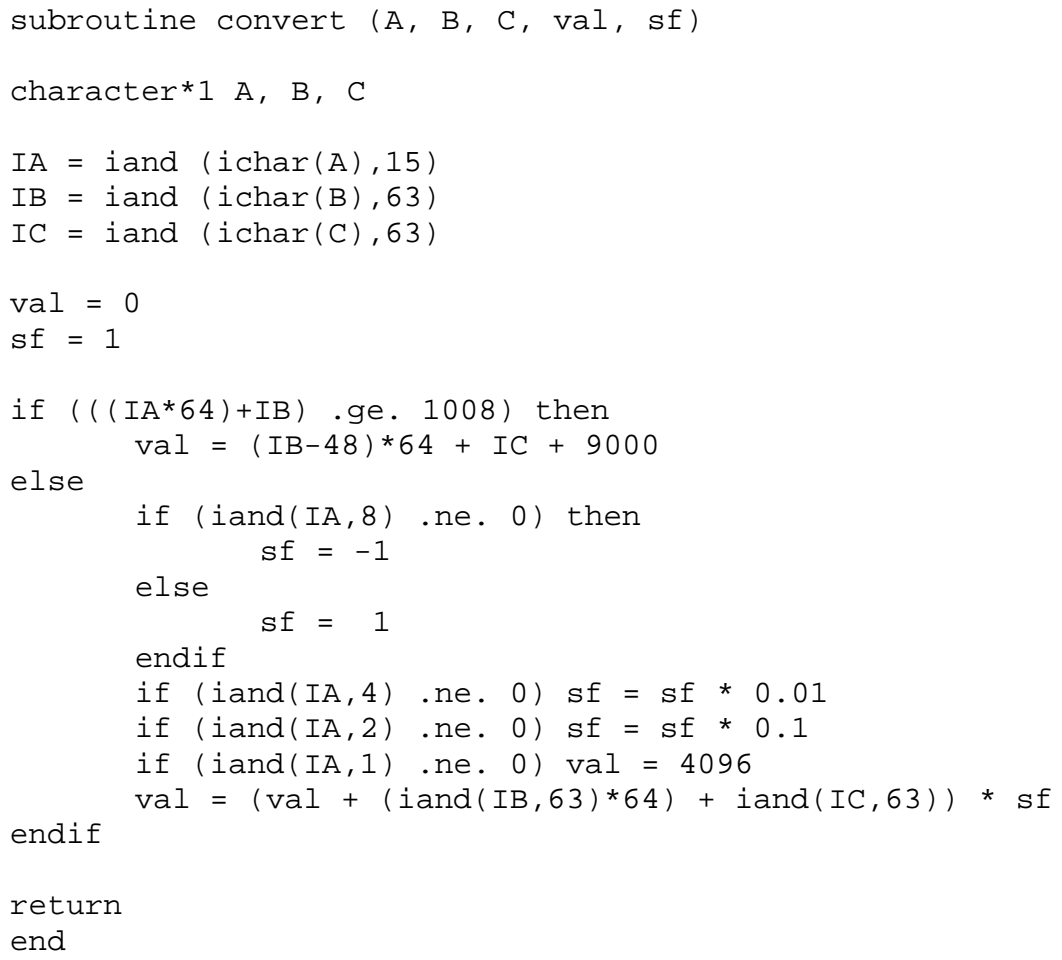




\section{Appendix D}

\section{Monthly Plots of Hourly Data}
A. Wind Speed
B. Wind Direction
C. Air temperature
D. Relative humidity

E. Box RH

F. Cumulative rainfall

G. Incoming sunlight (Starting April 2001) 


\section{A. Wind Speed}
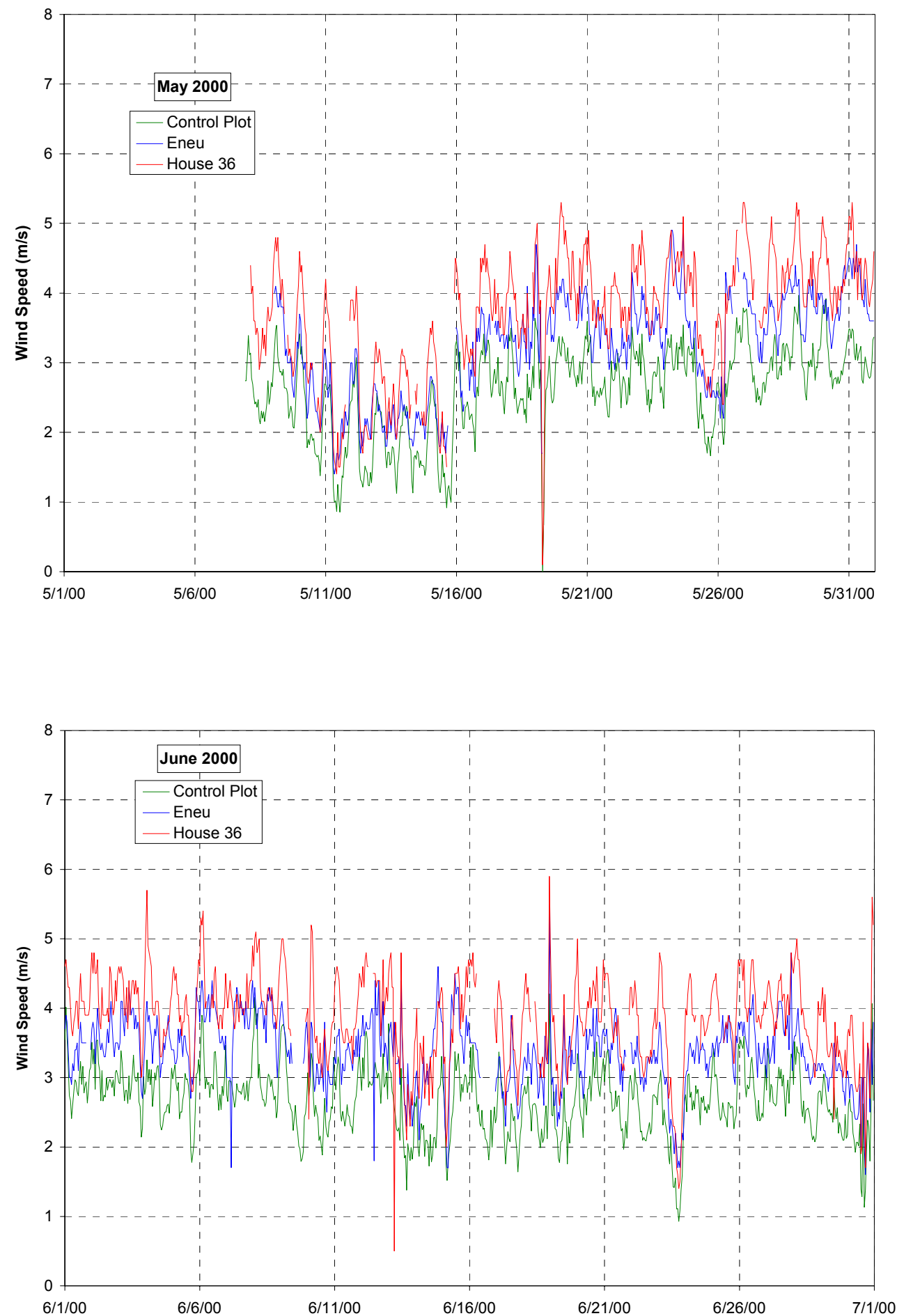

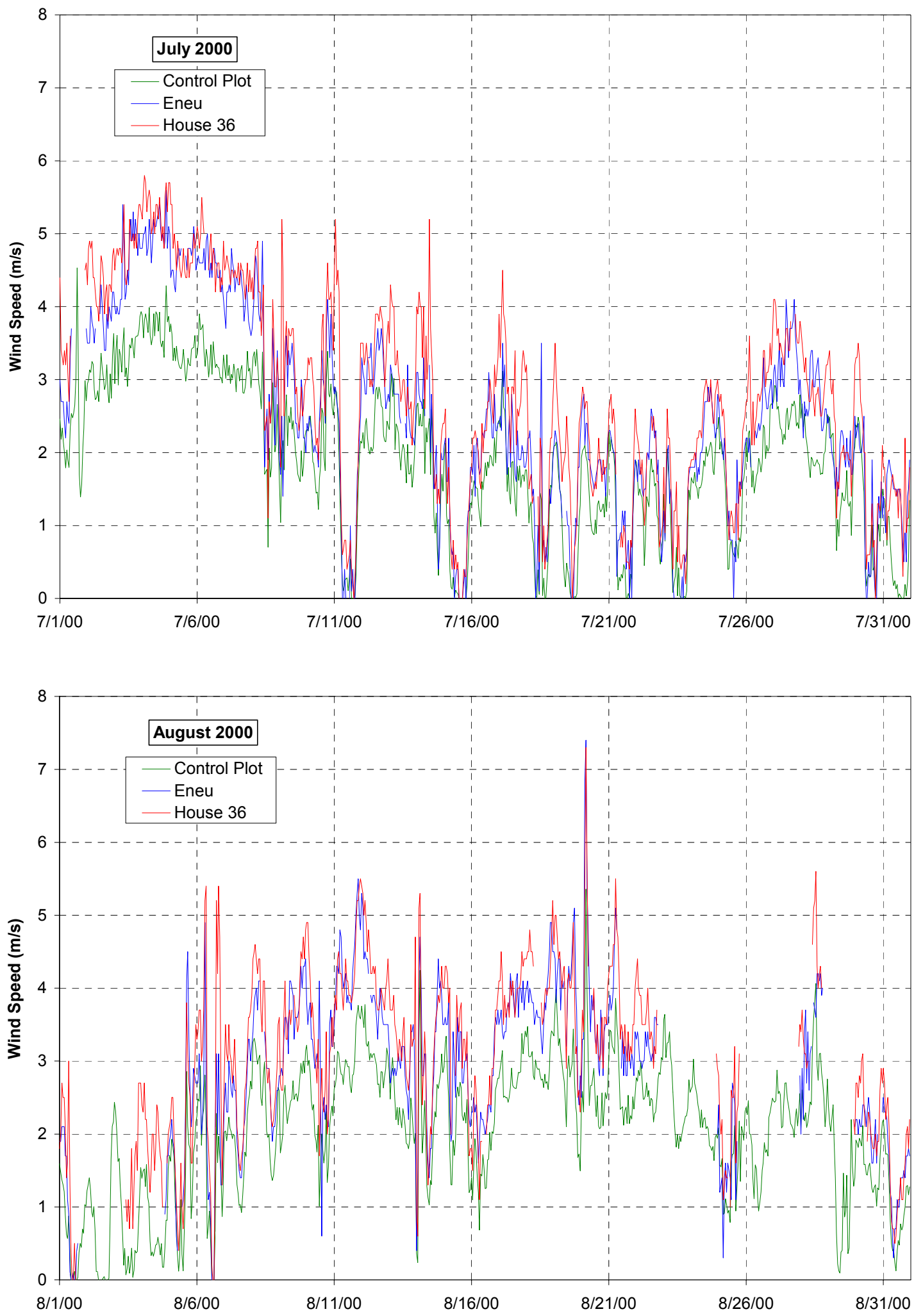

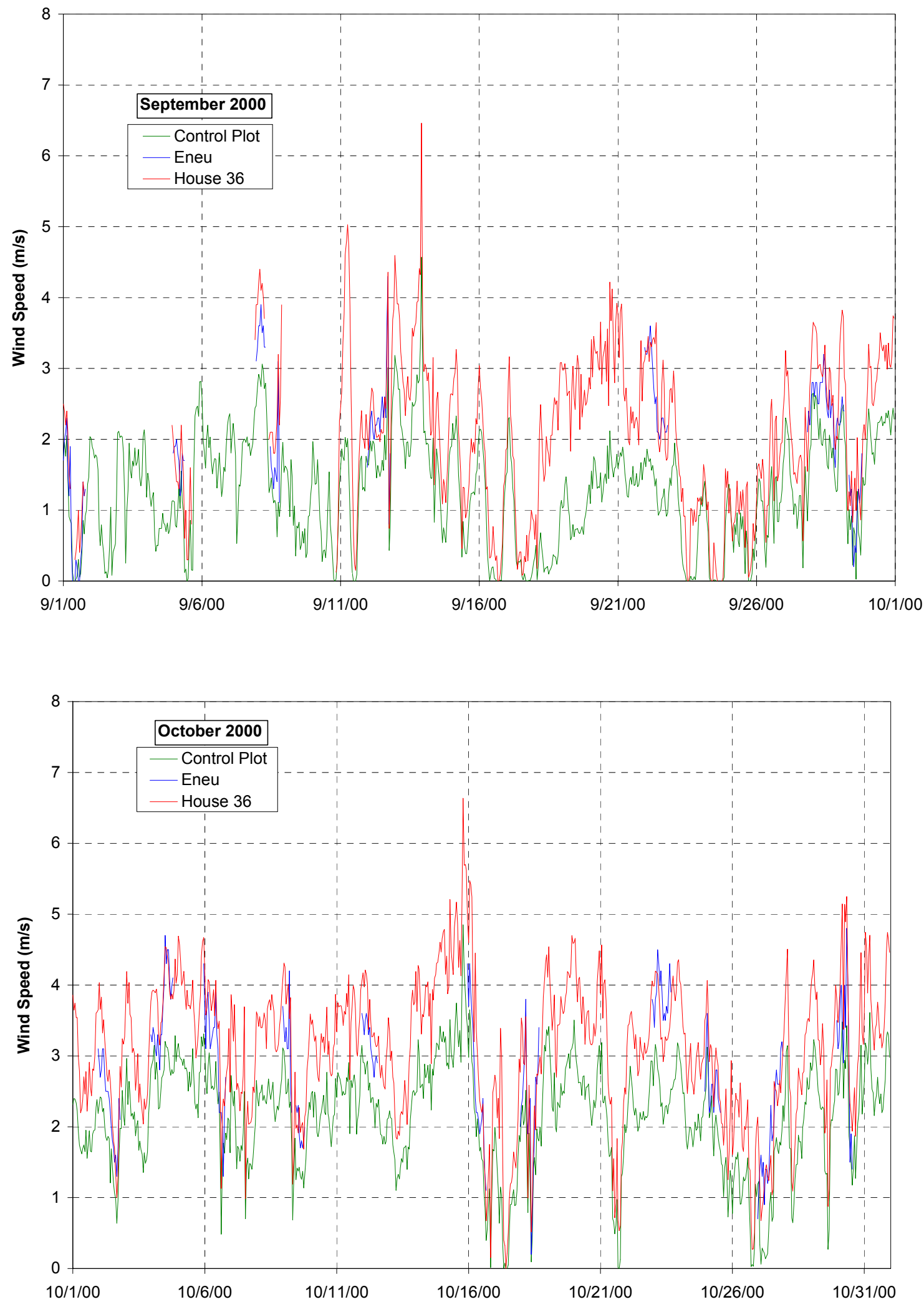

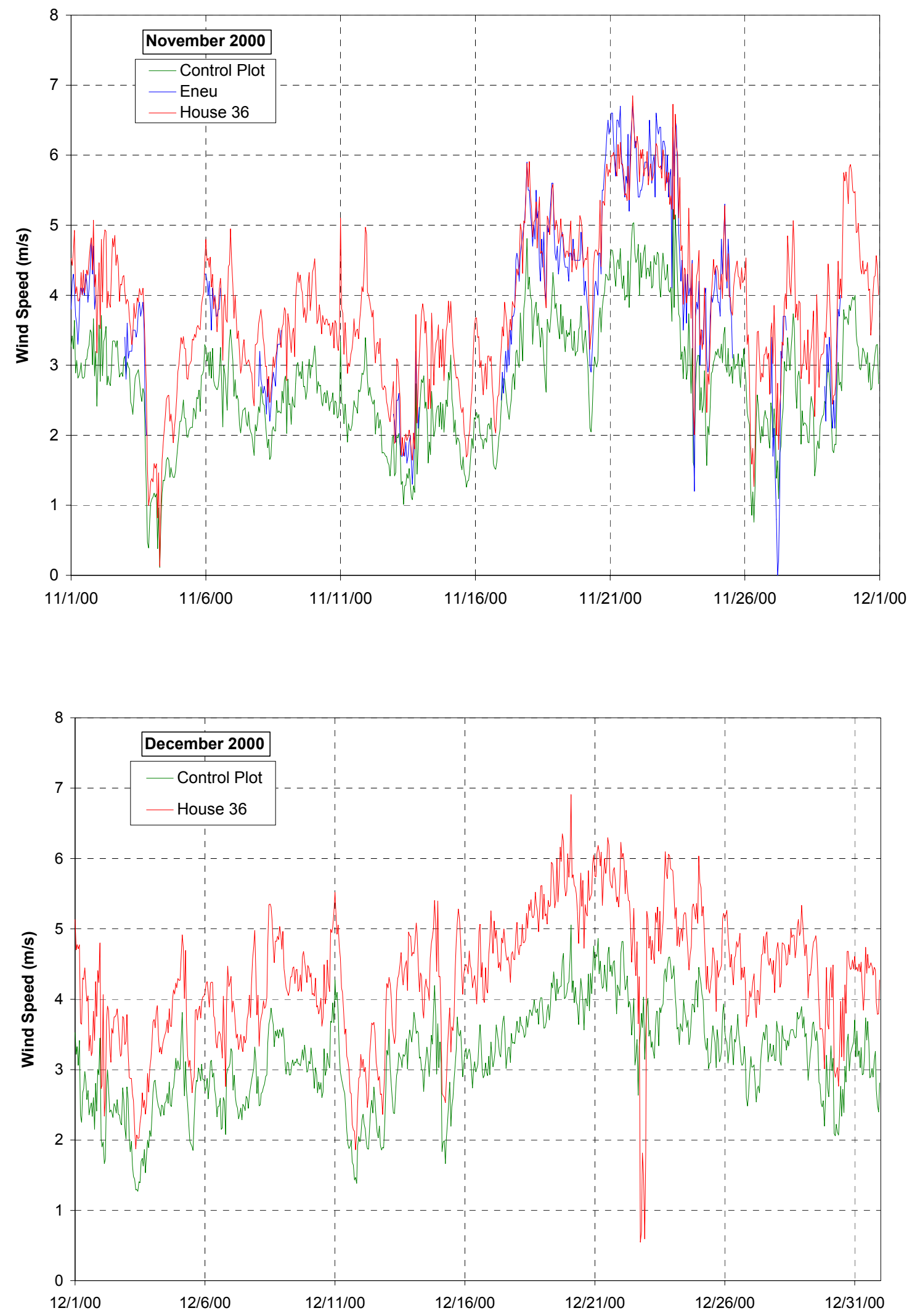

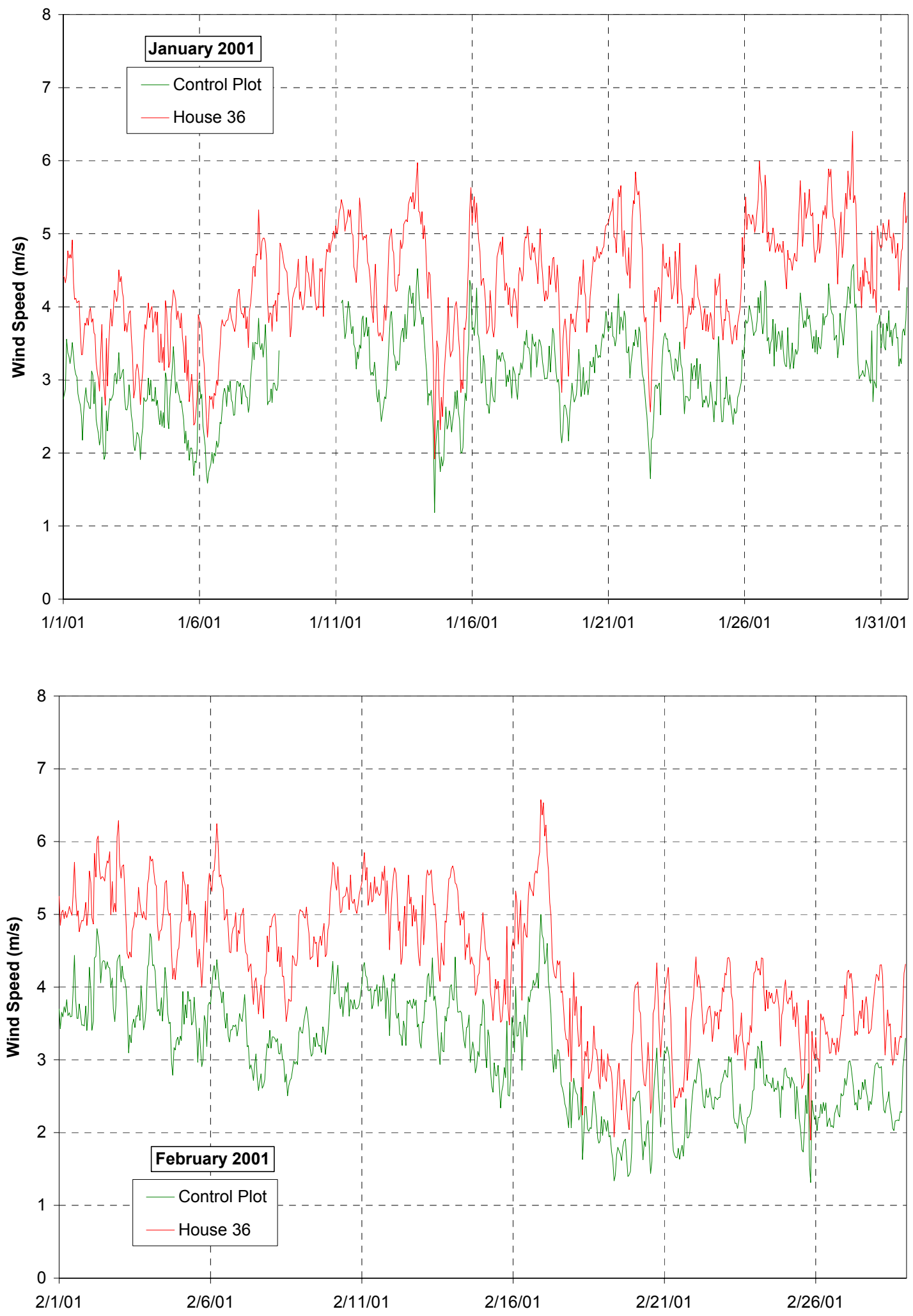

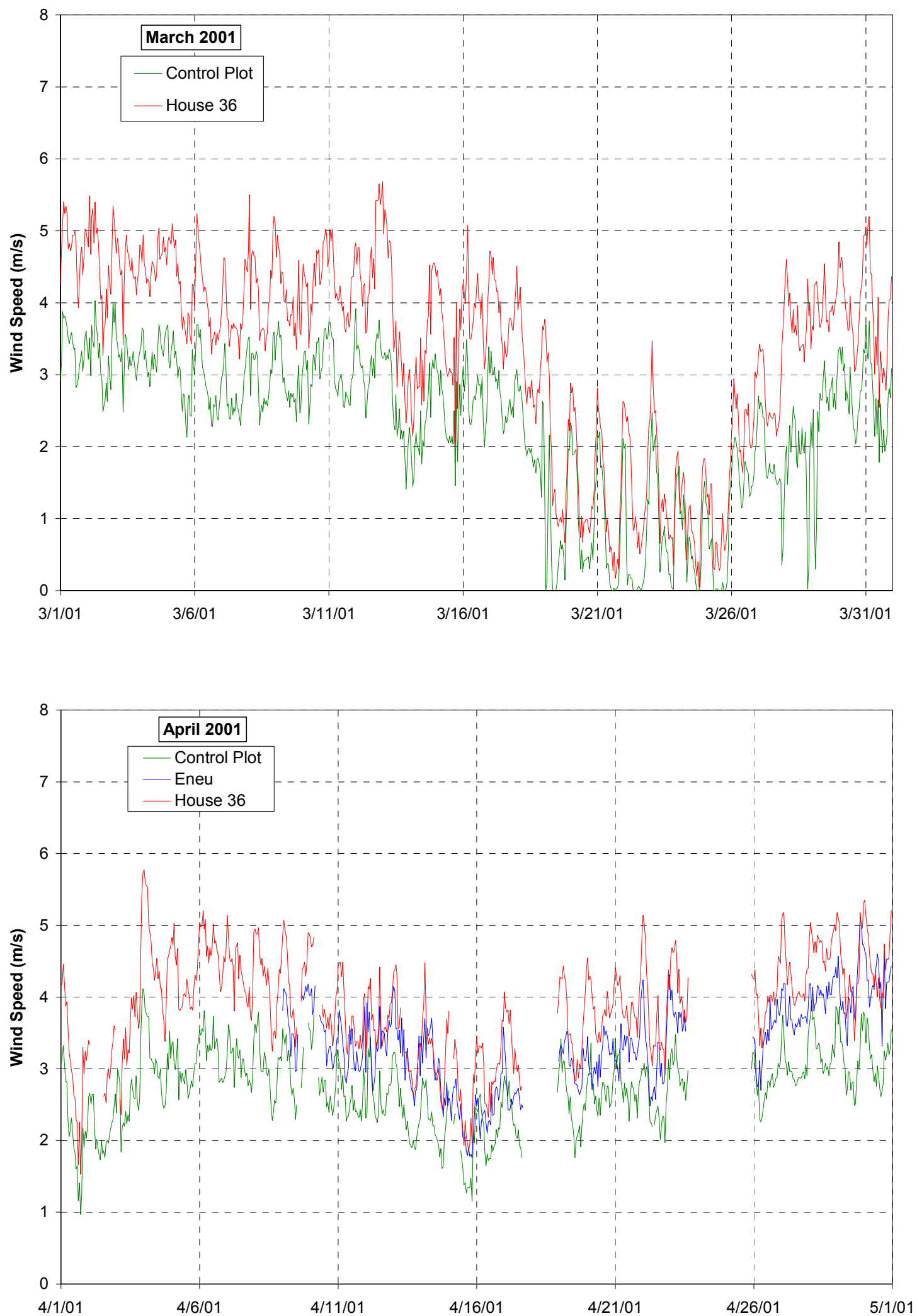
B. Wind Direction
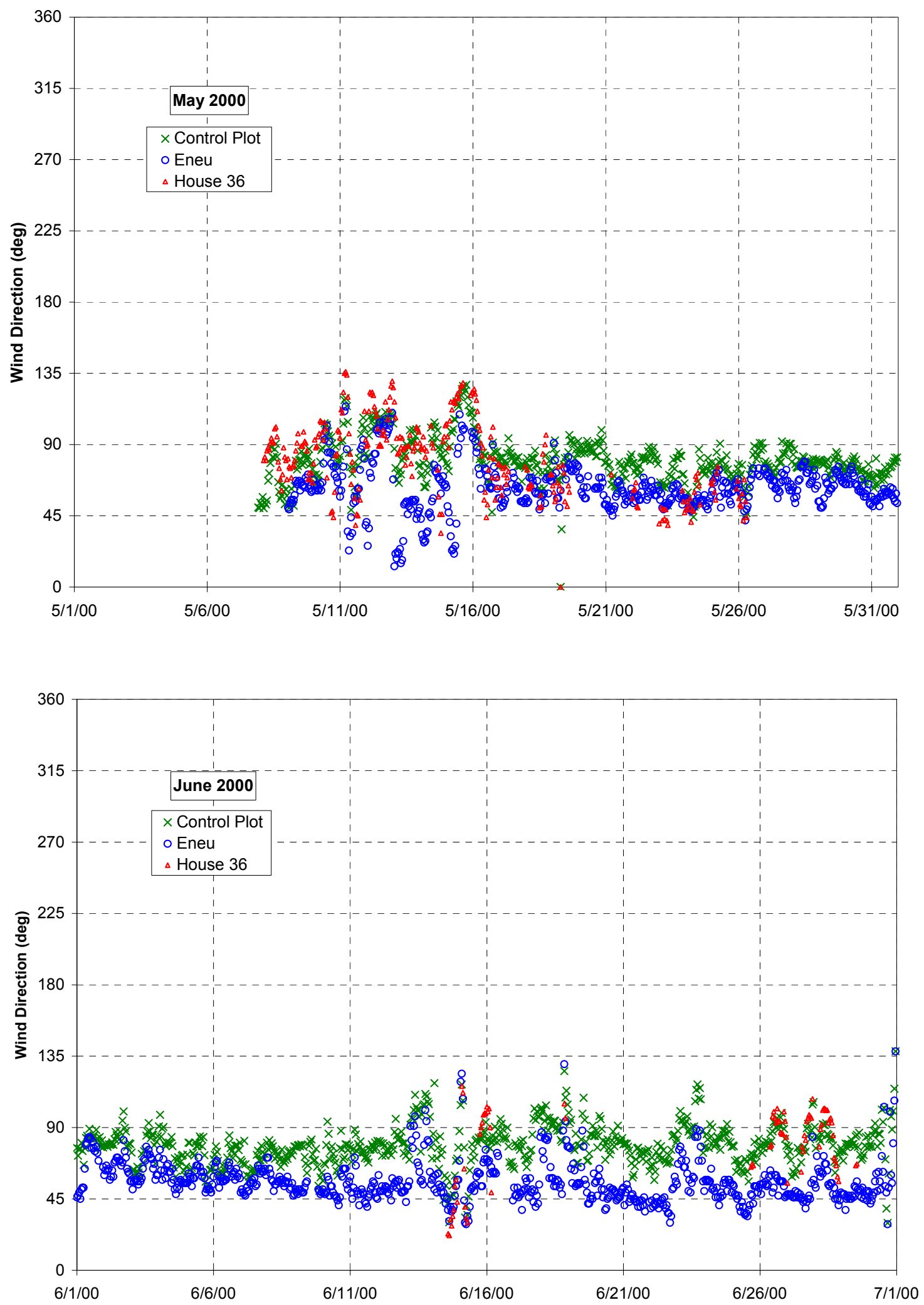

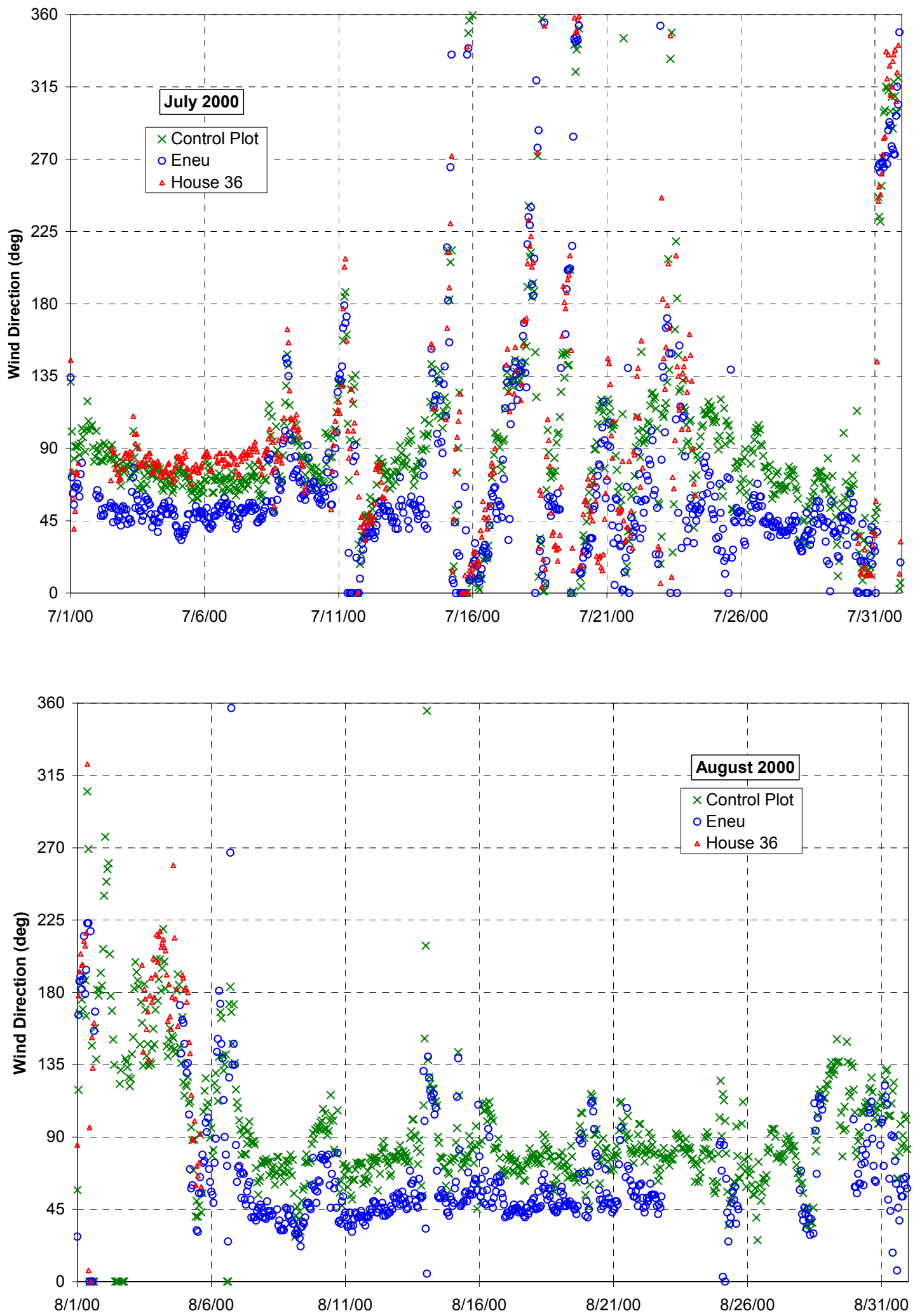

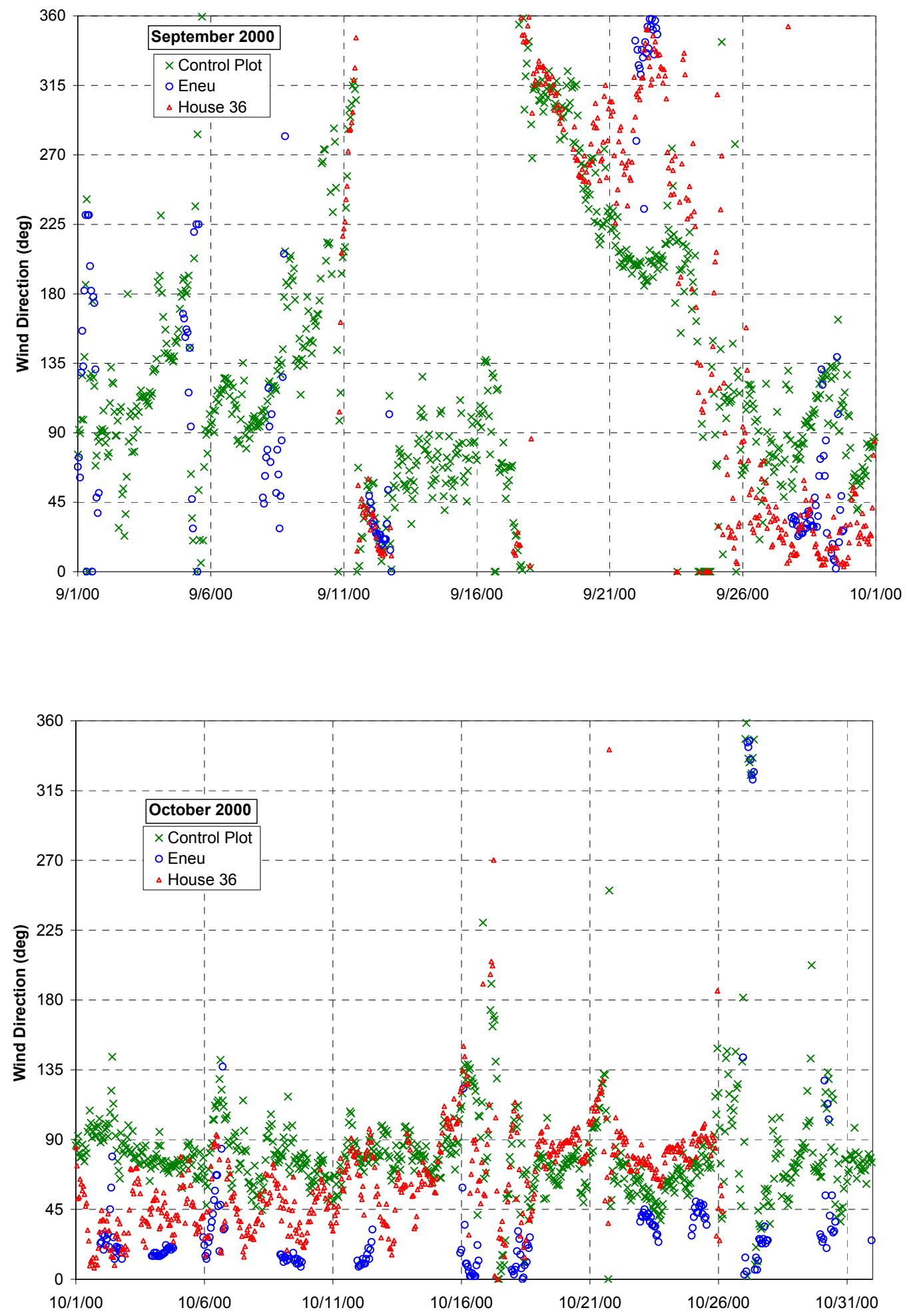

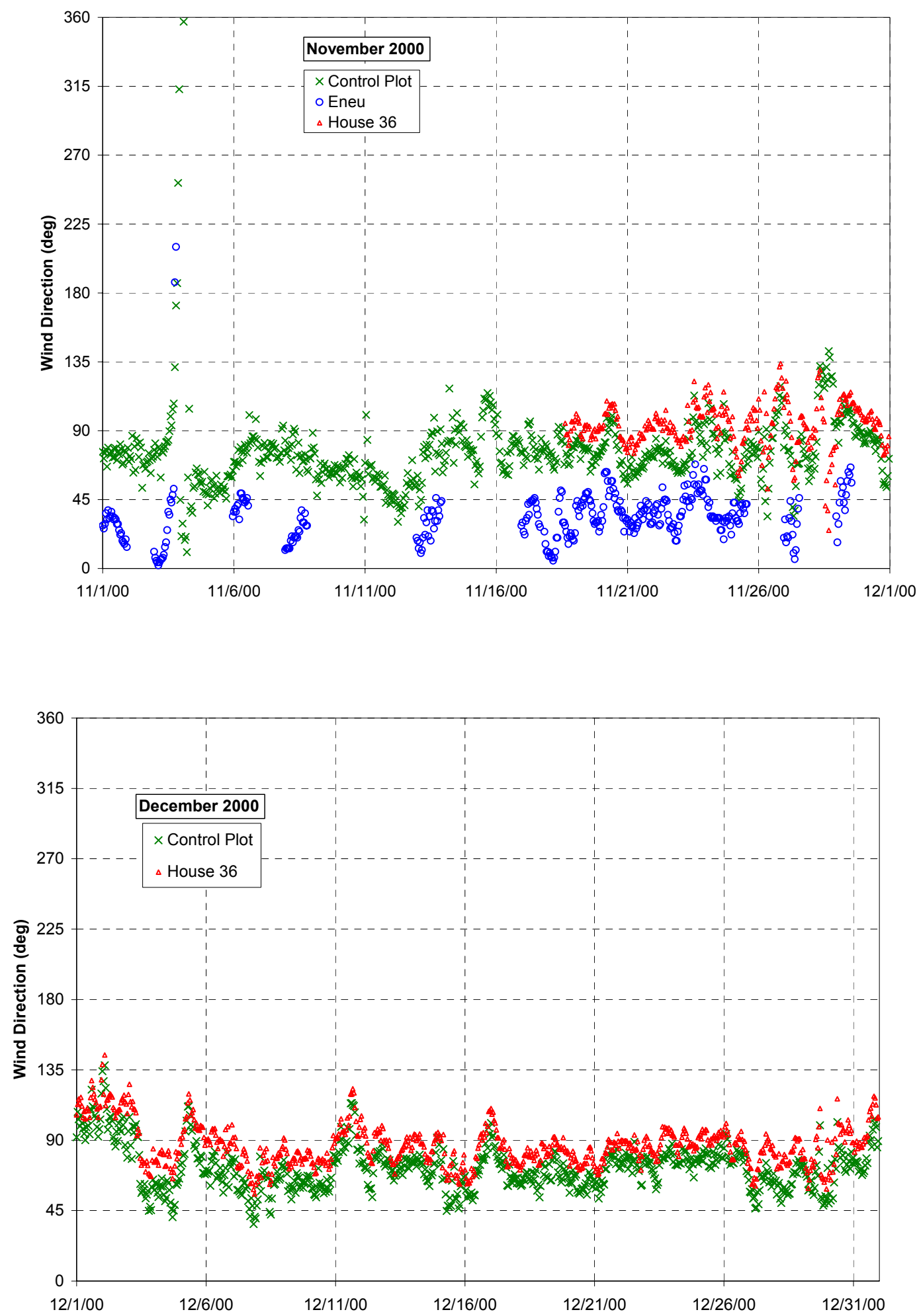

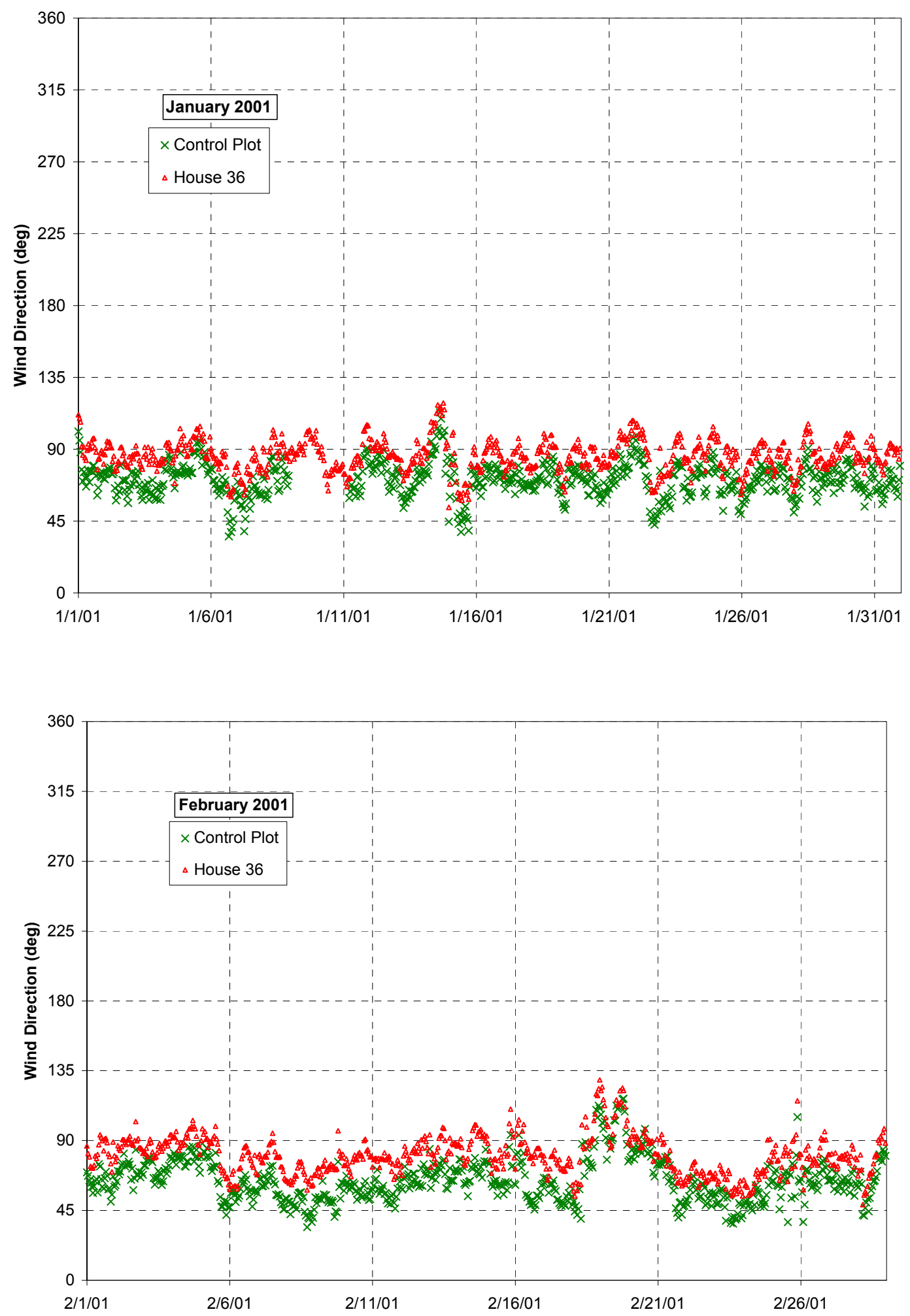

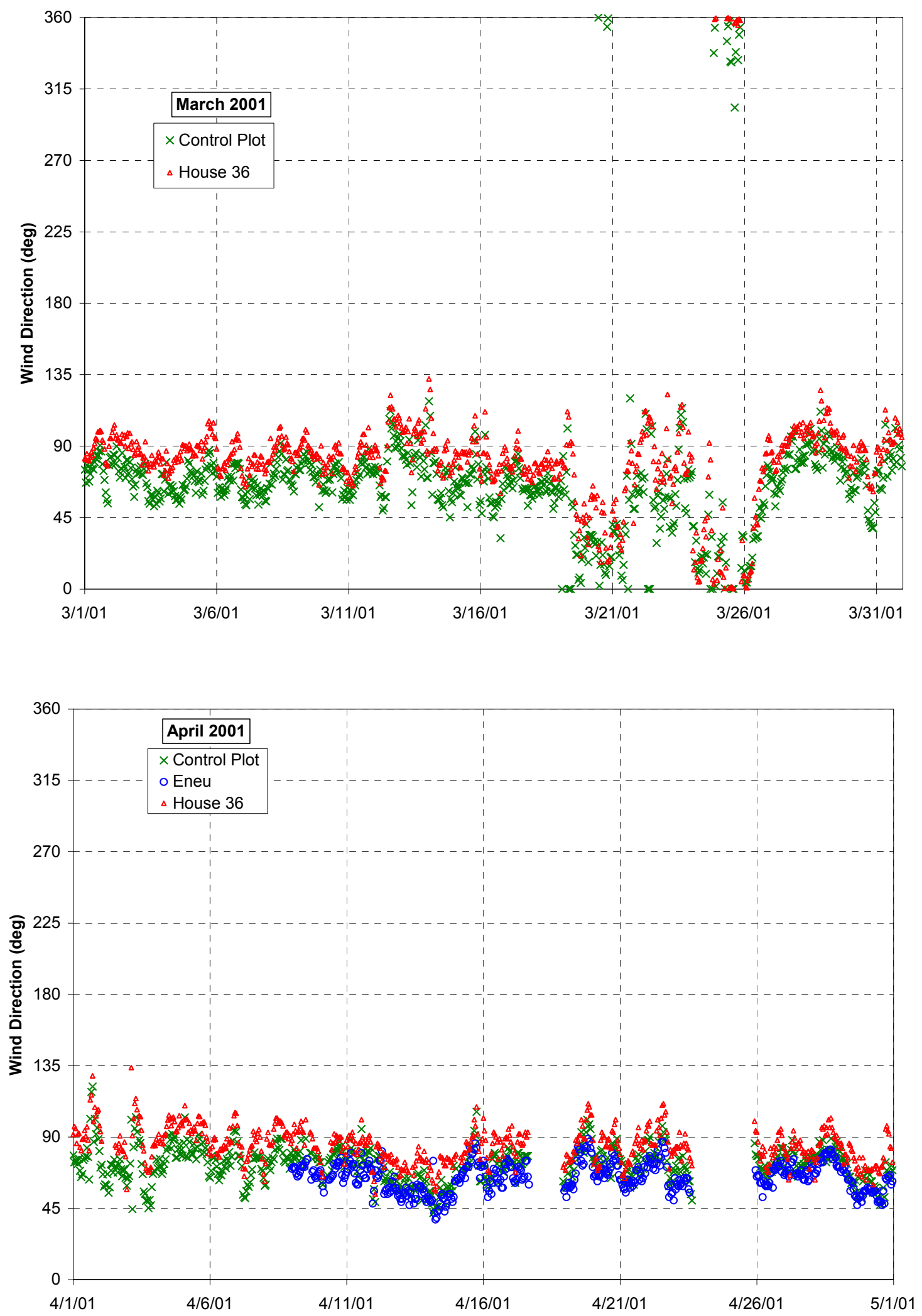


\section{Air temperature}
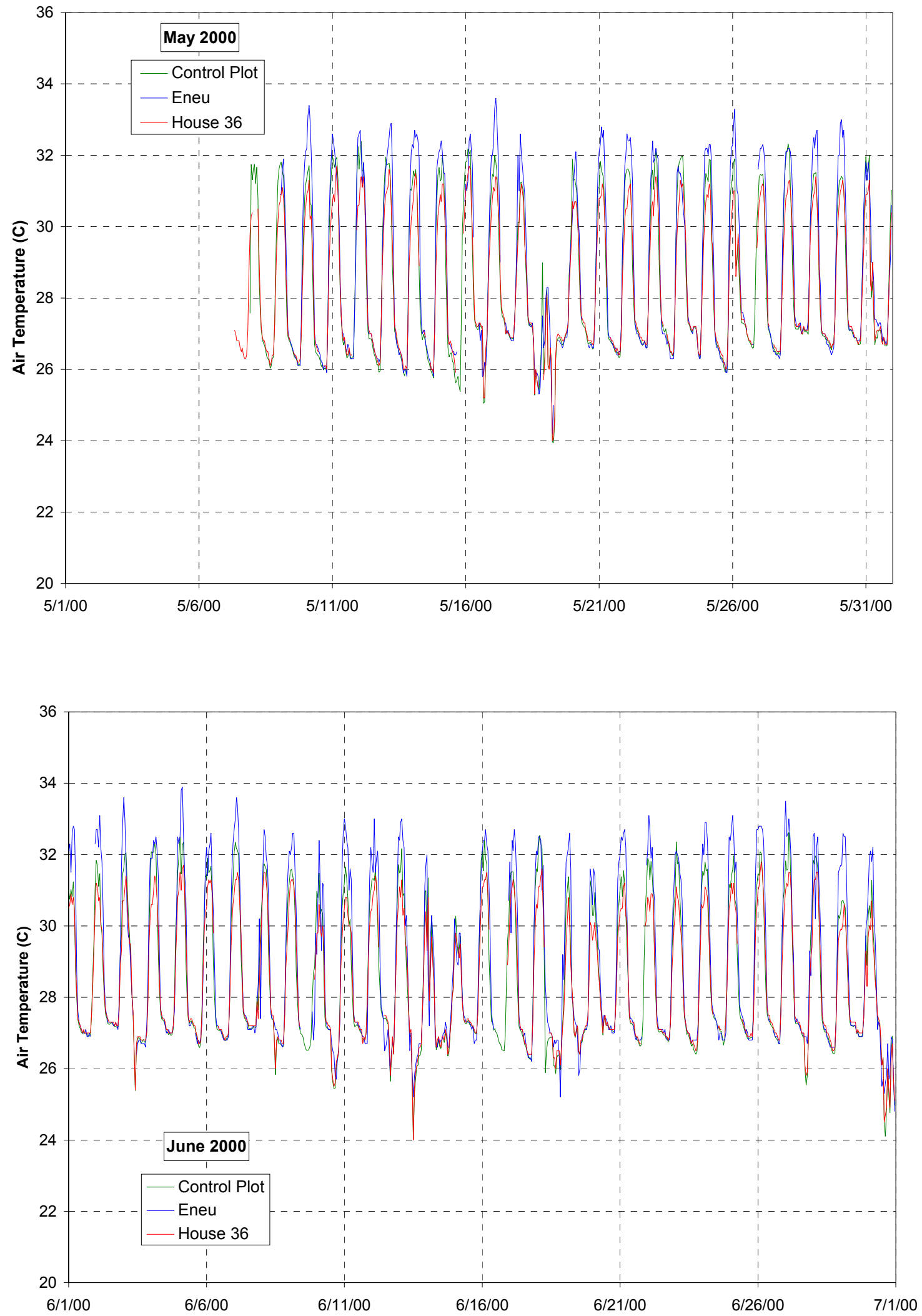

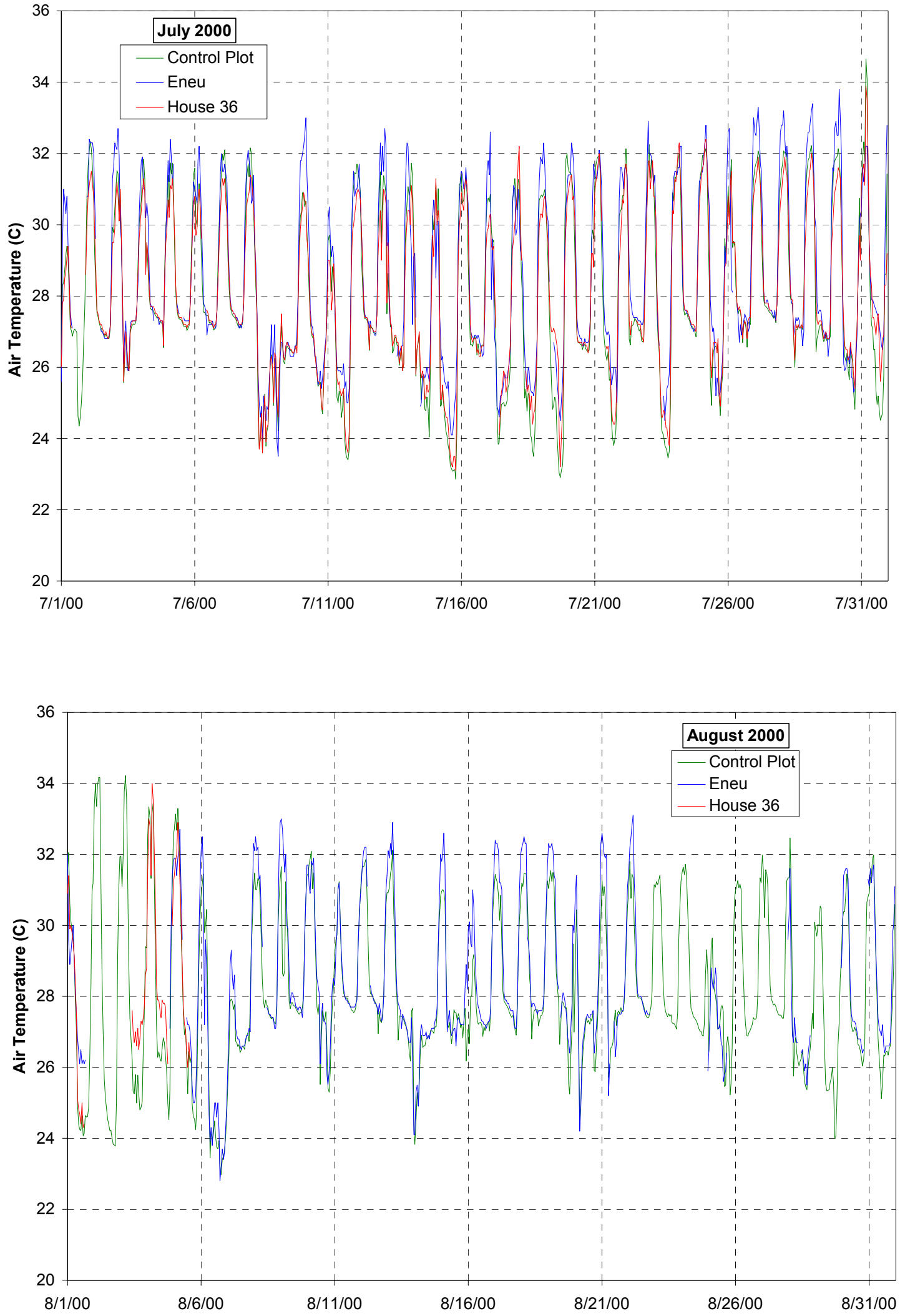

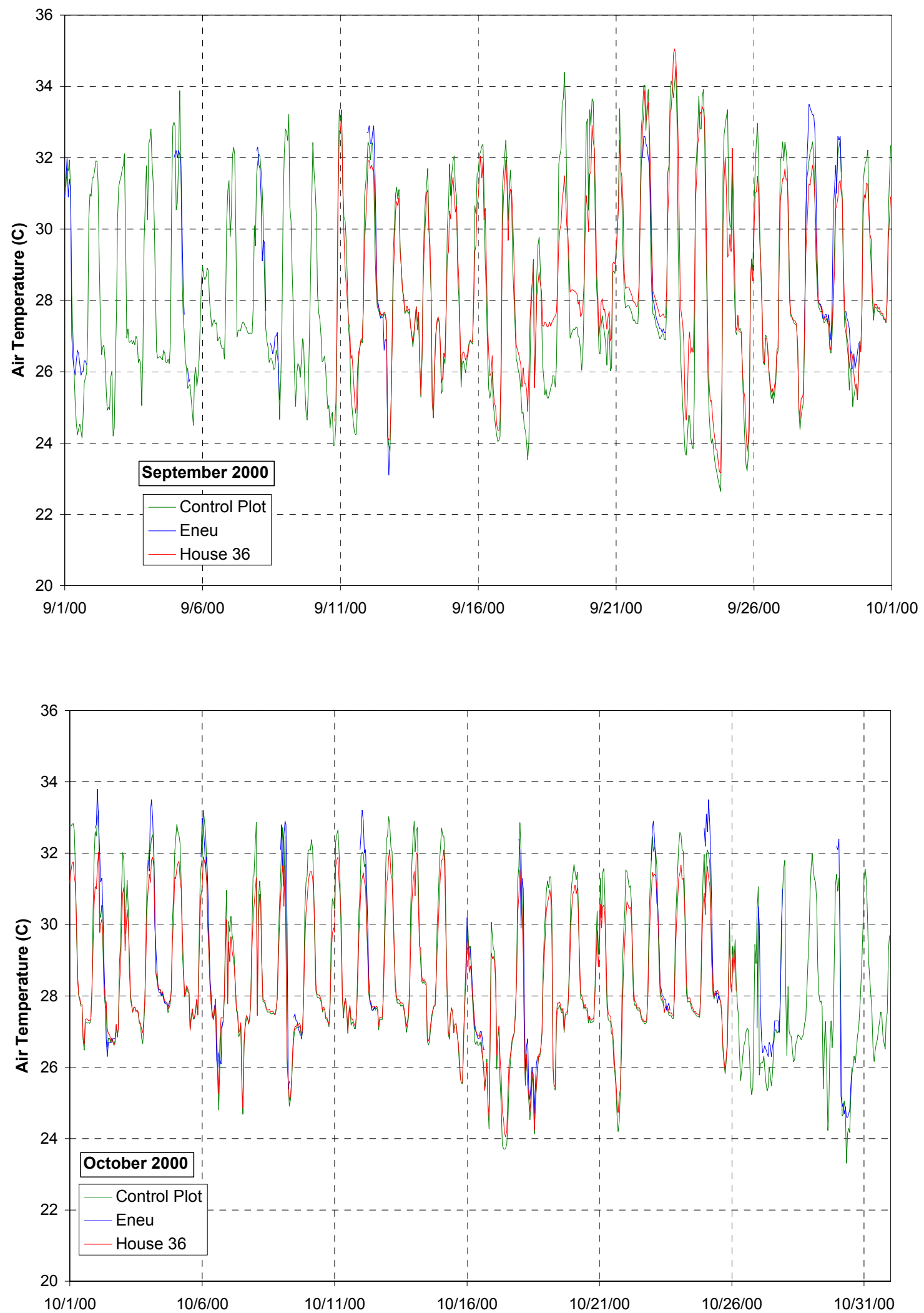

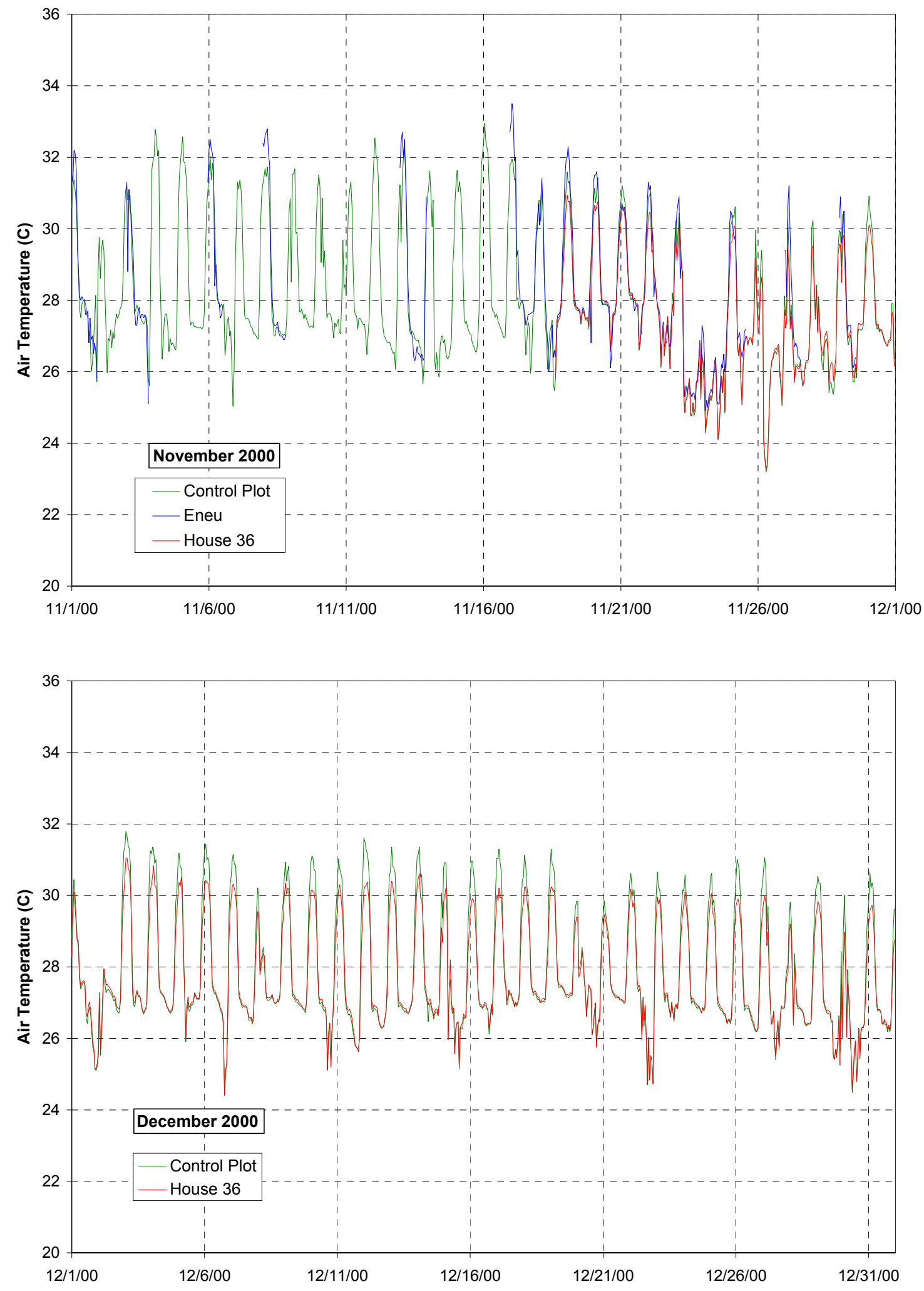

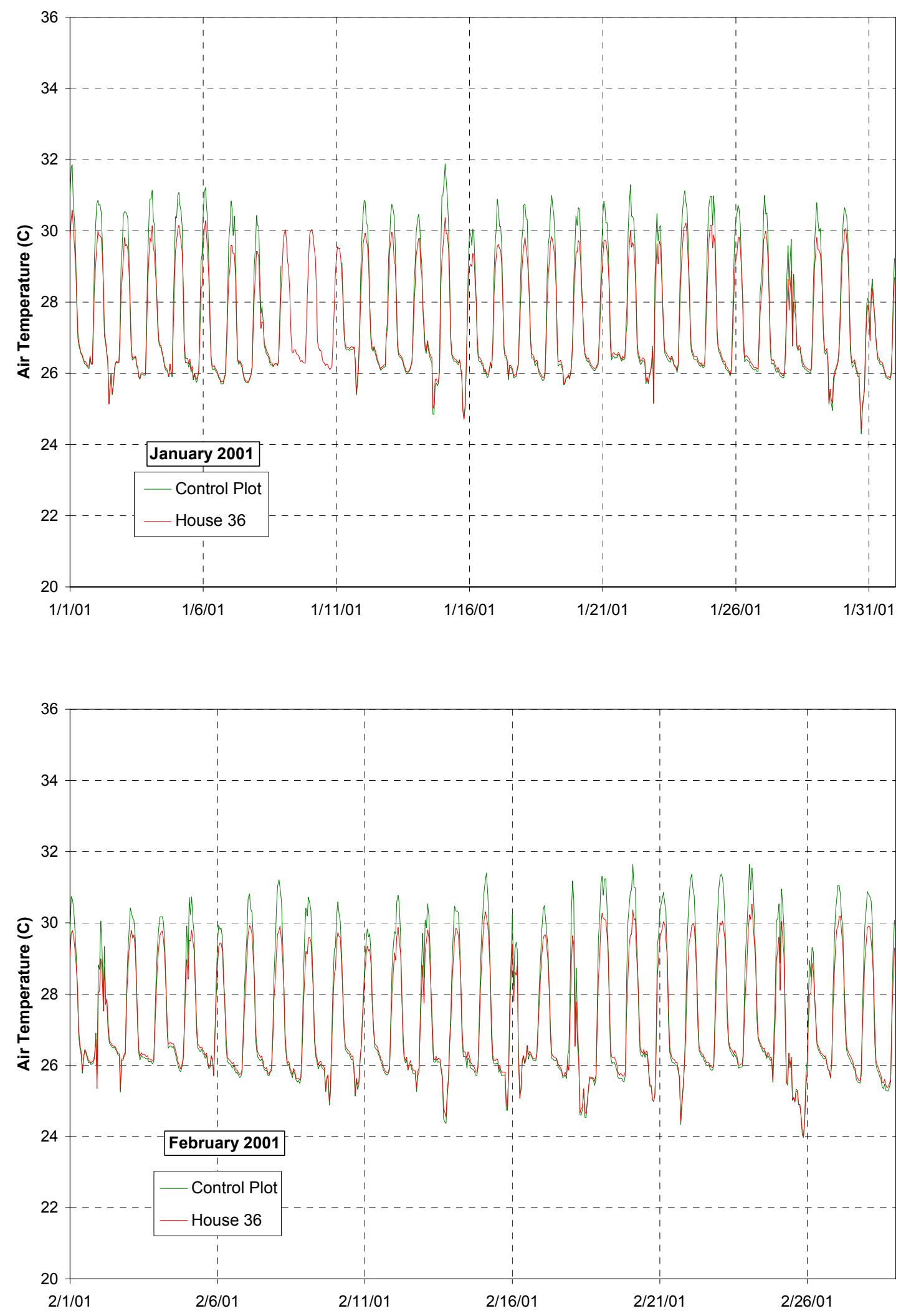

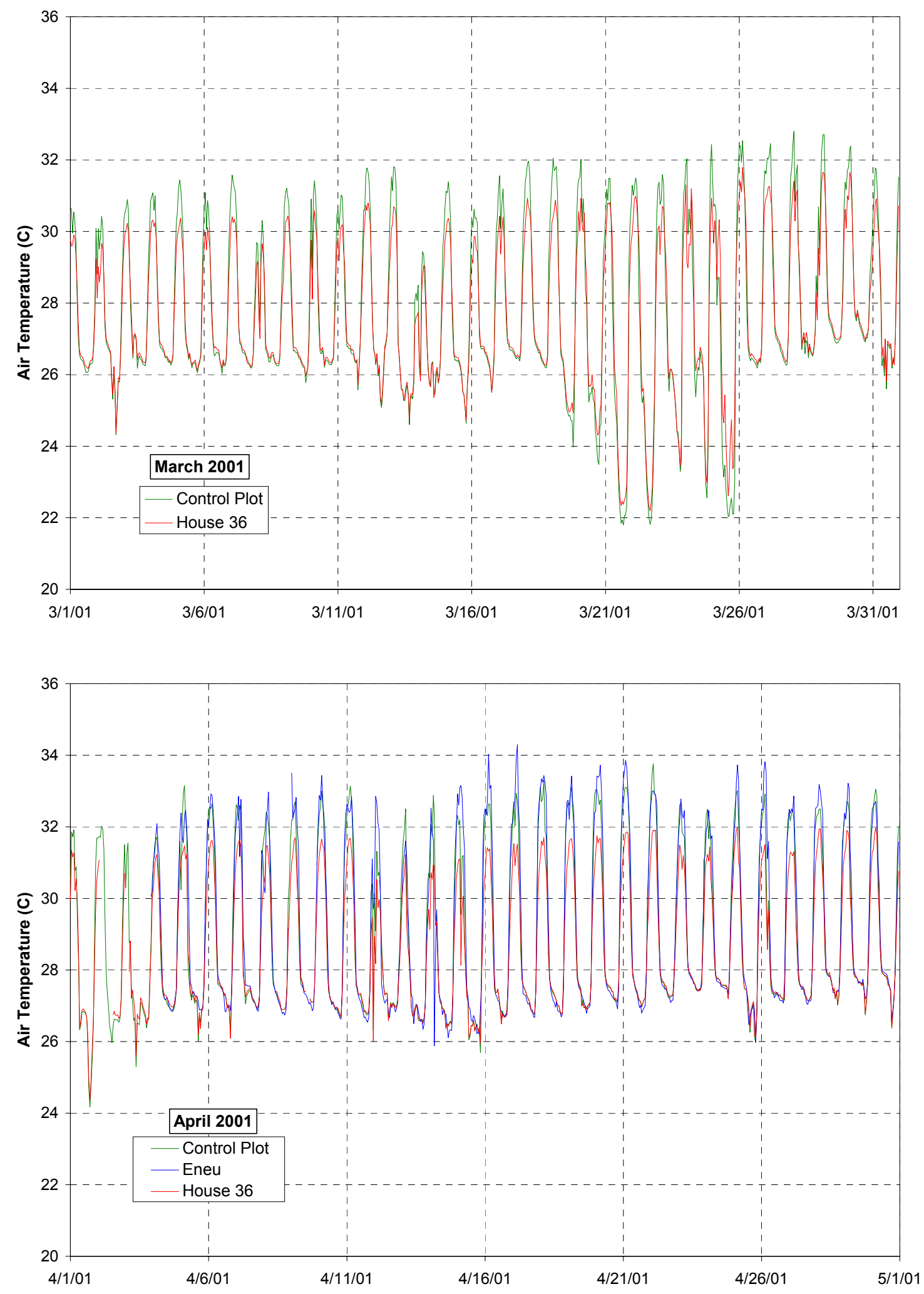


\section{Relative humidity}
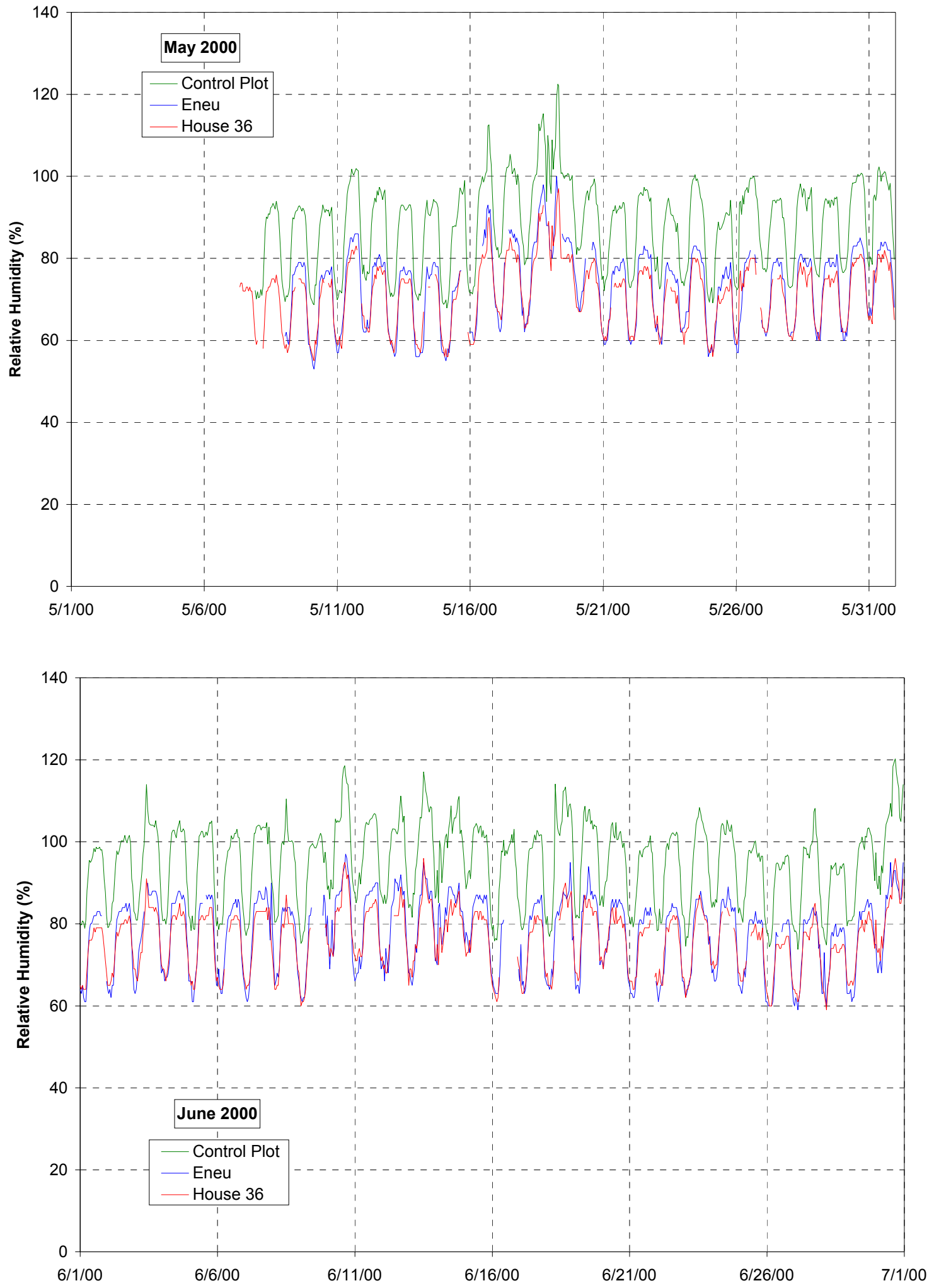

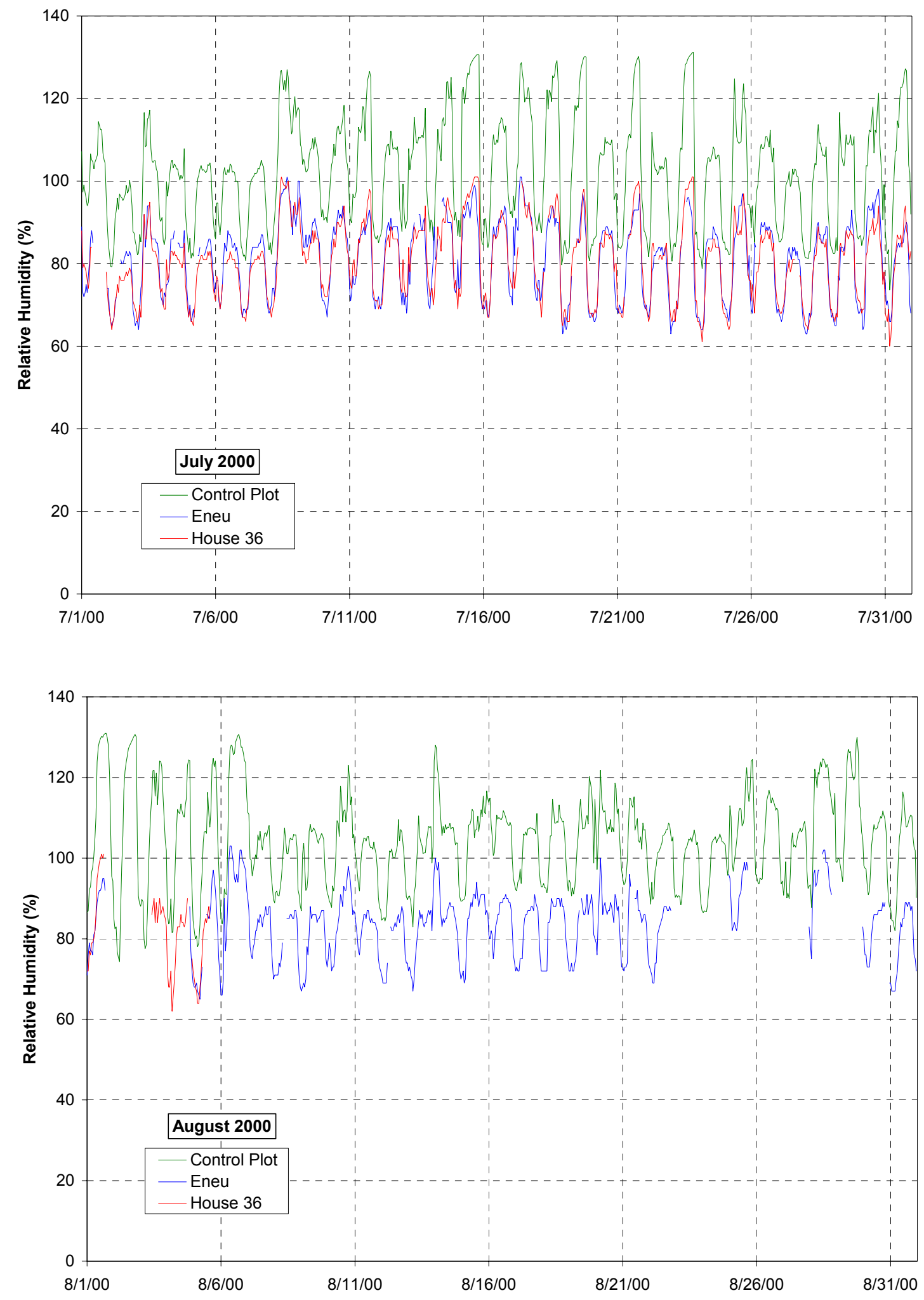

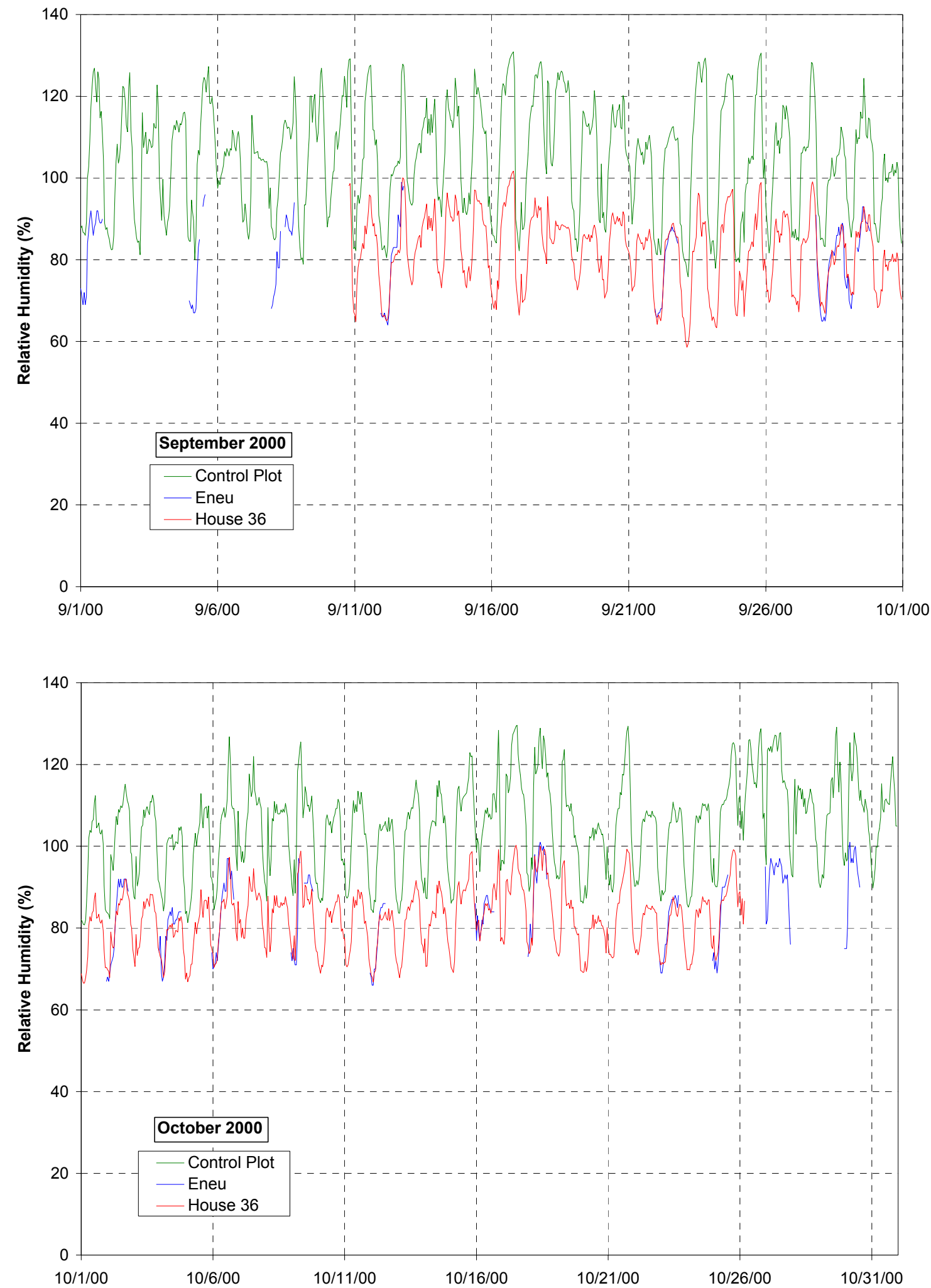

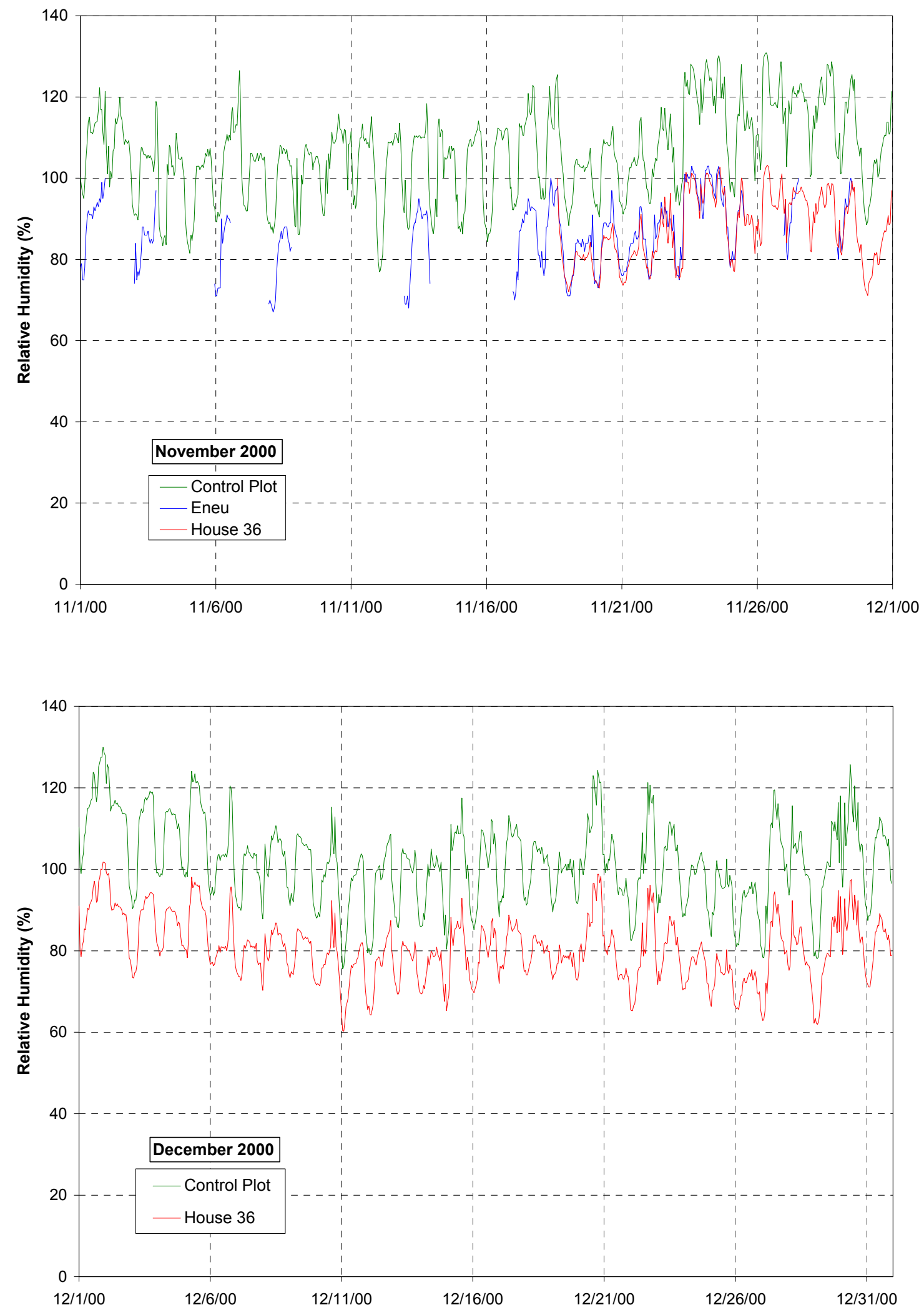

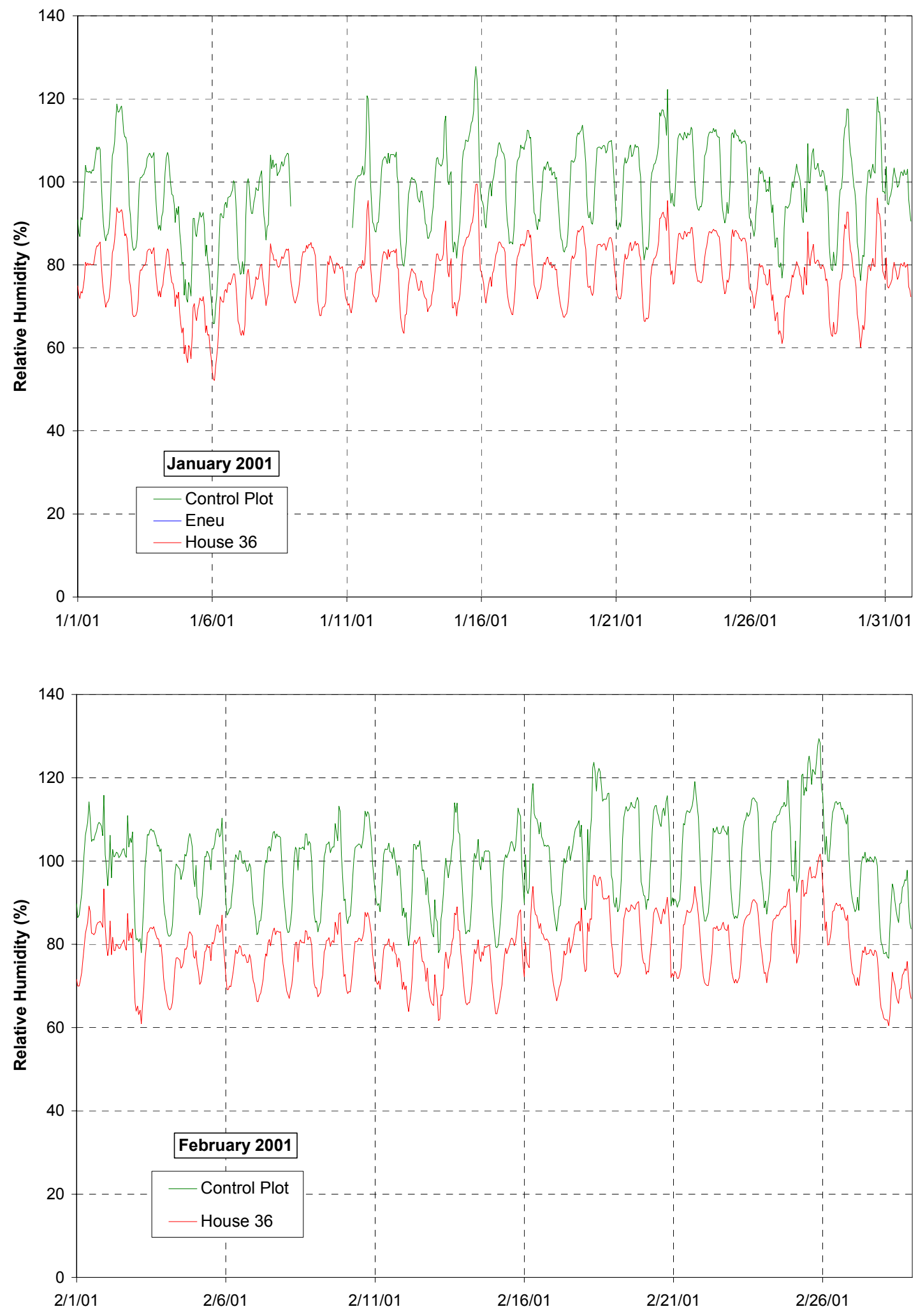

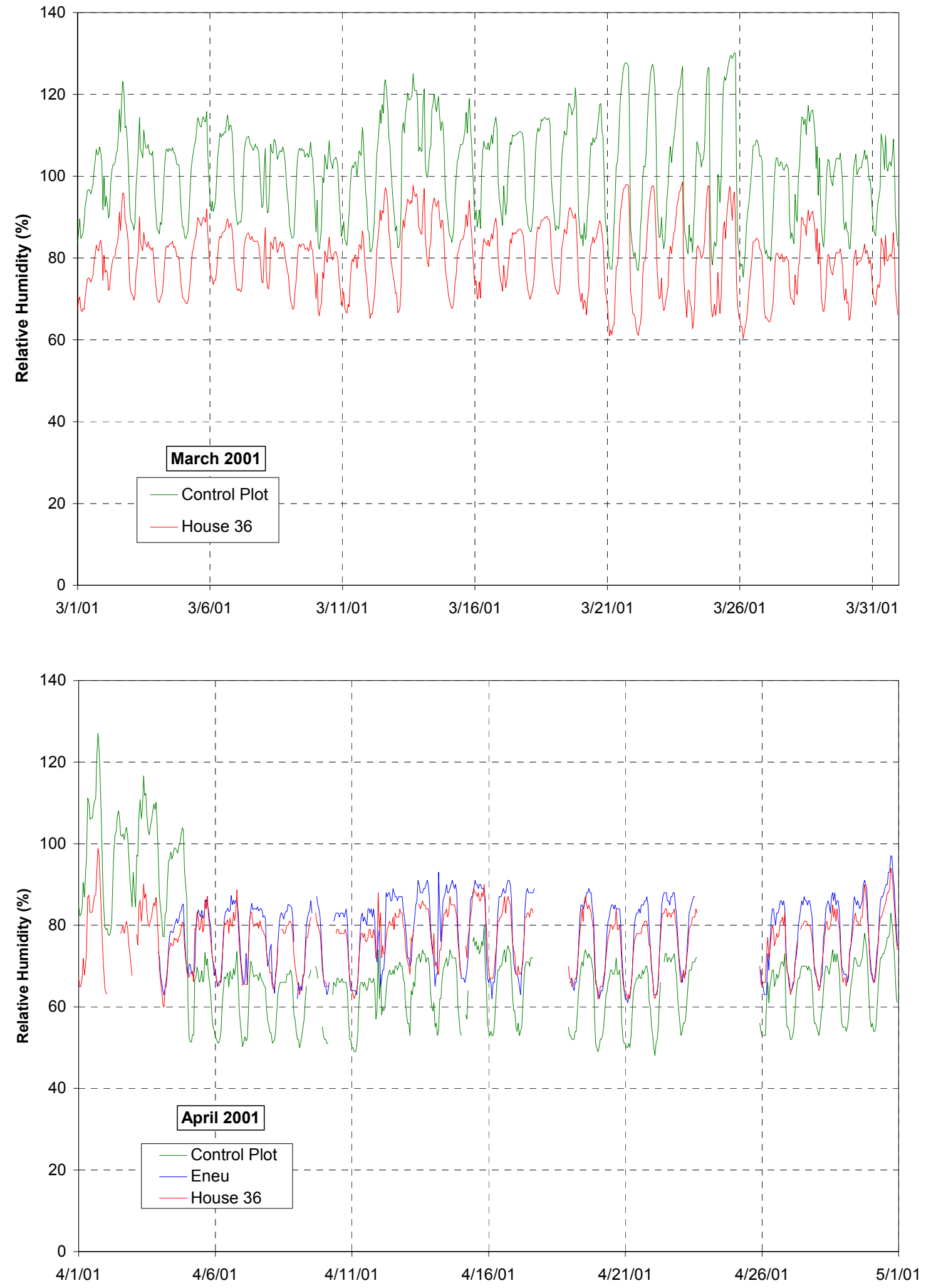


\section{E. Box RH}
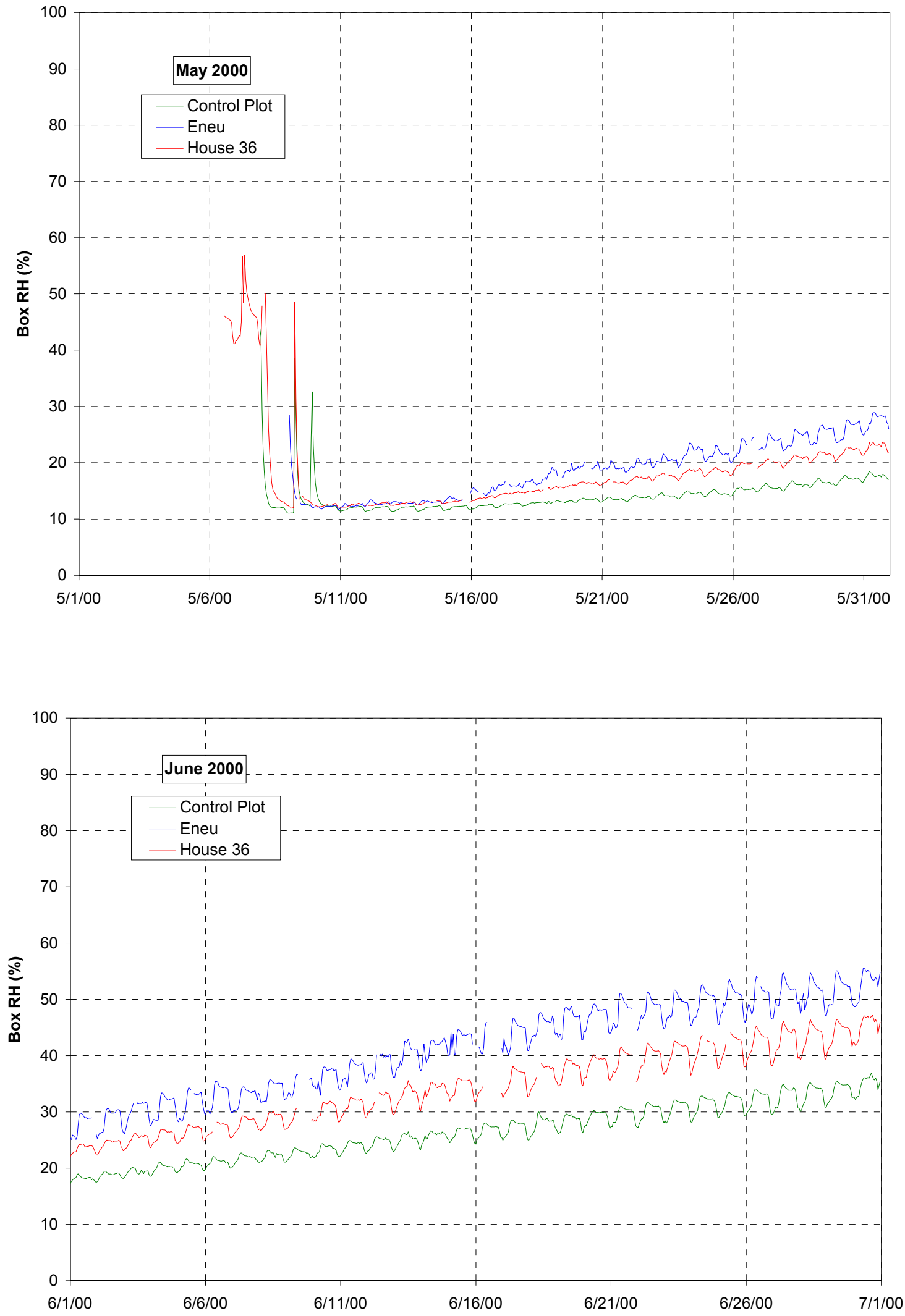

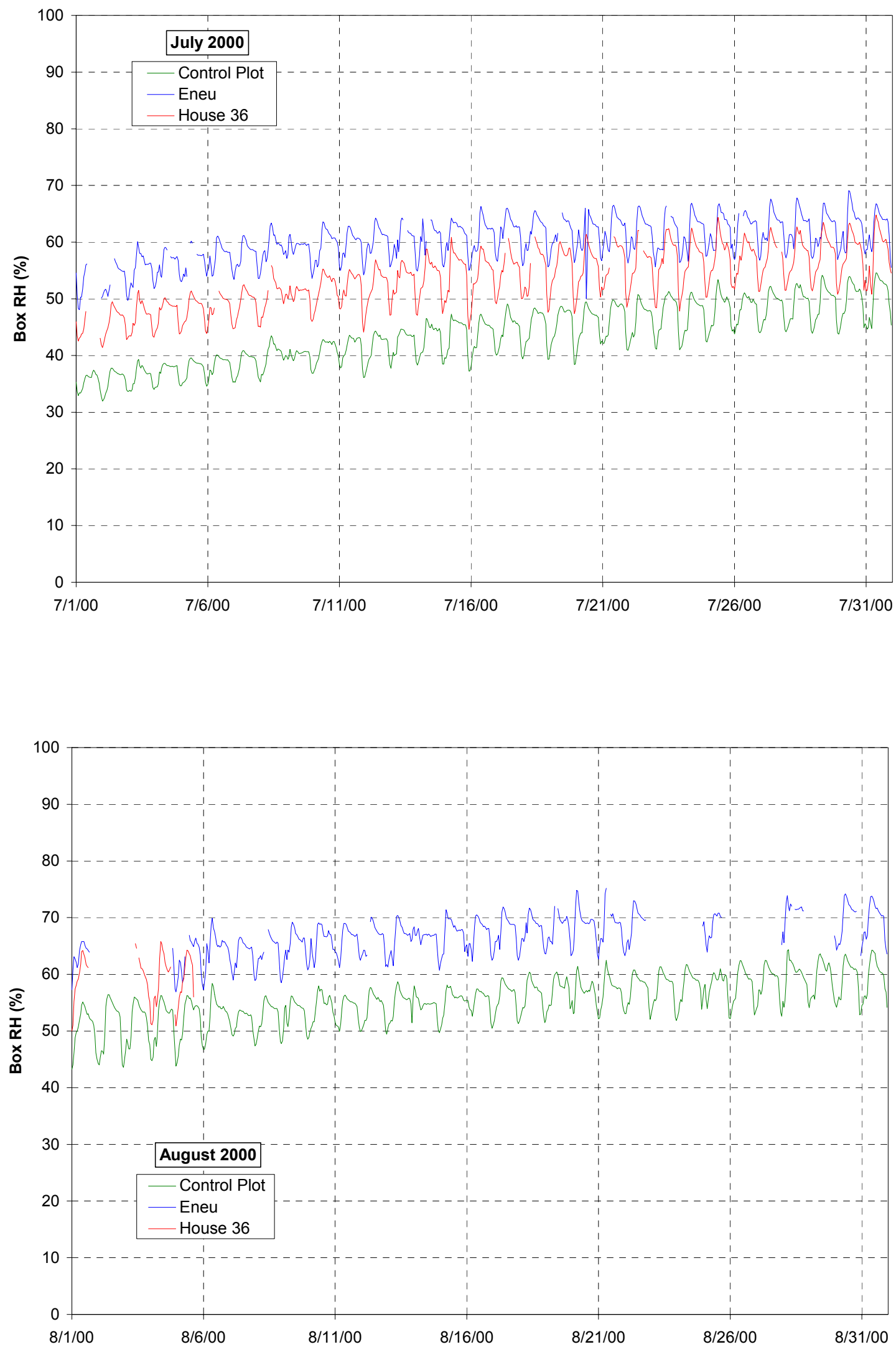

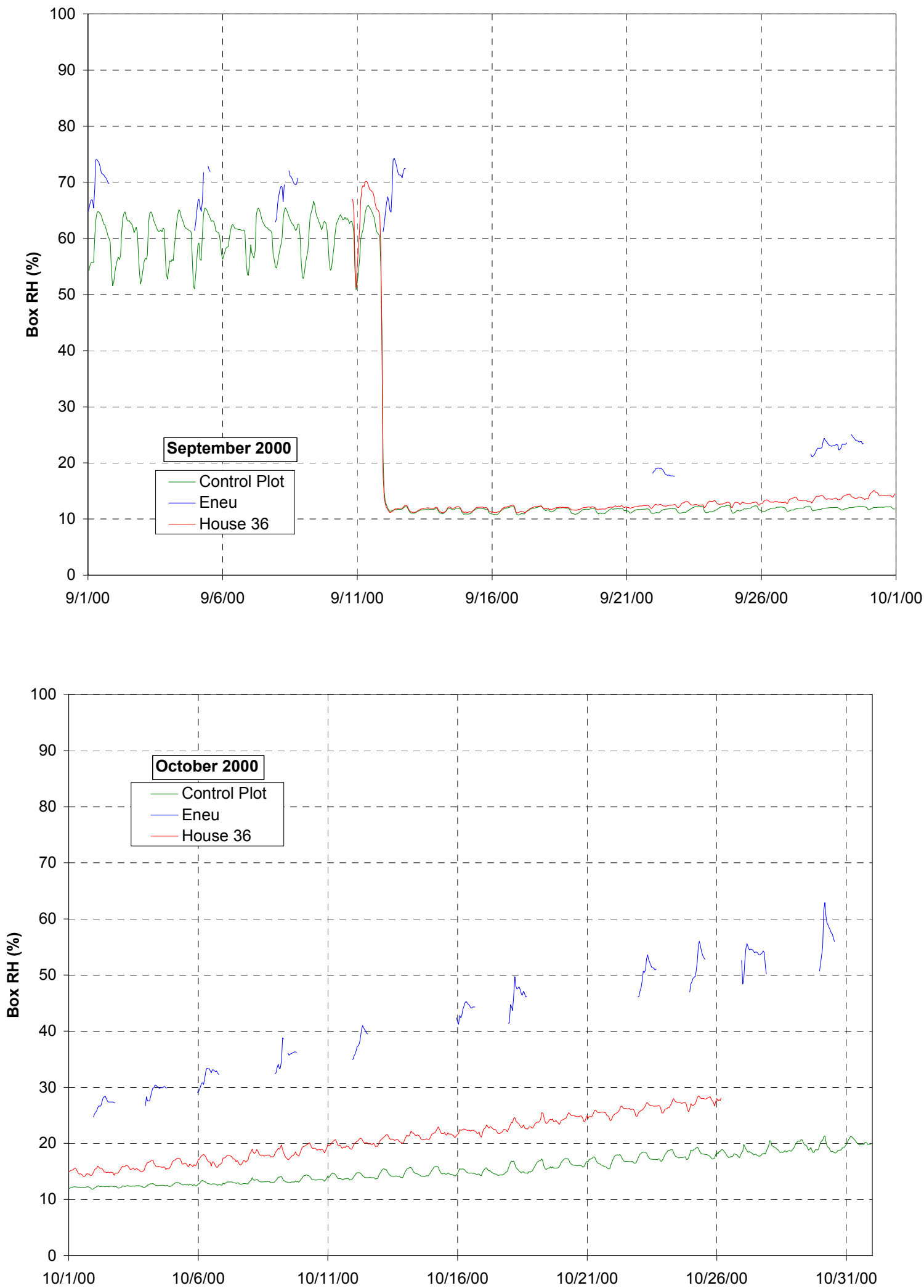

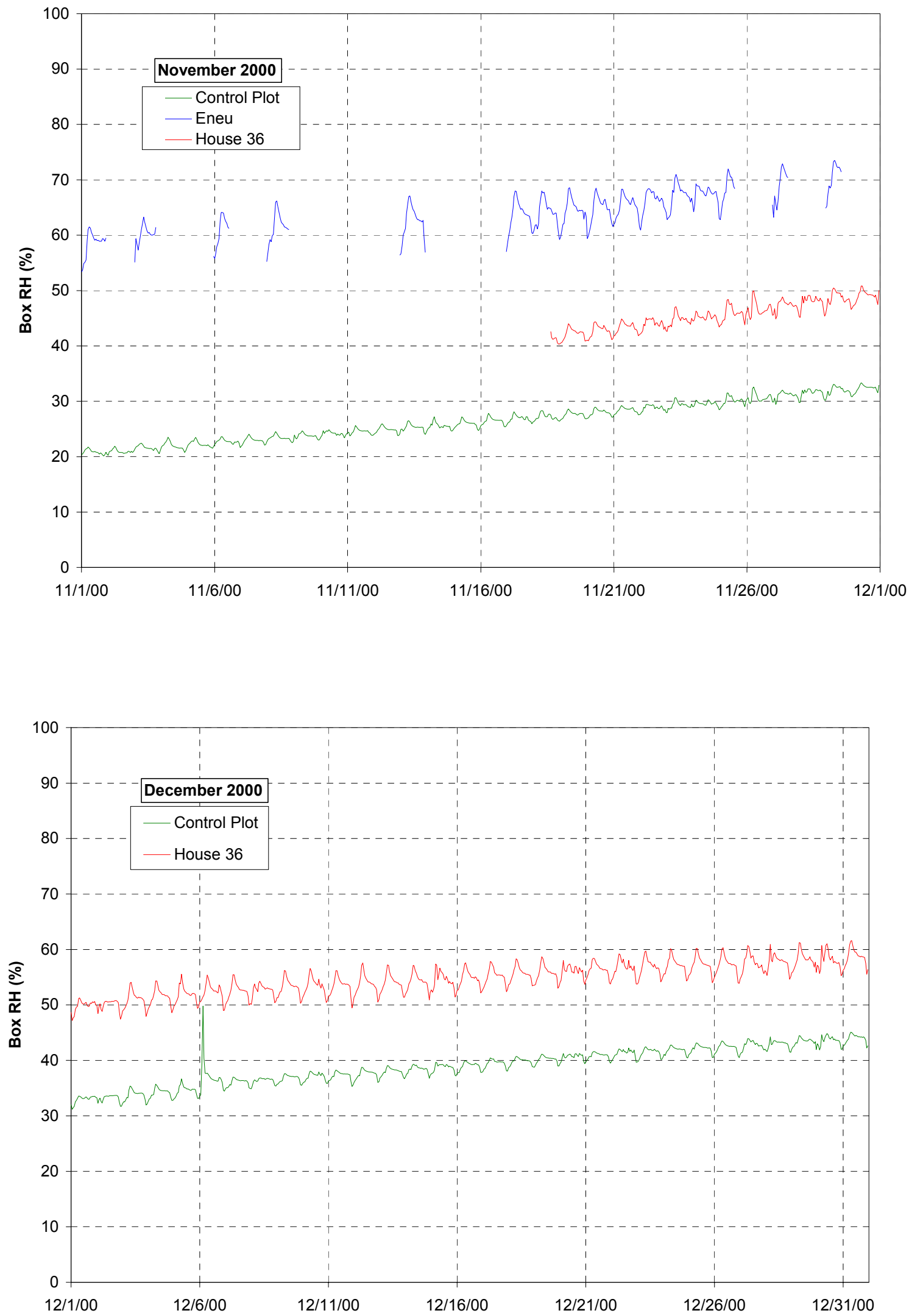

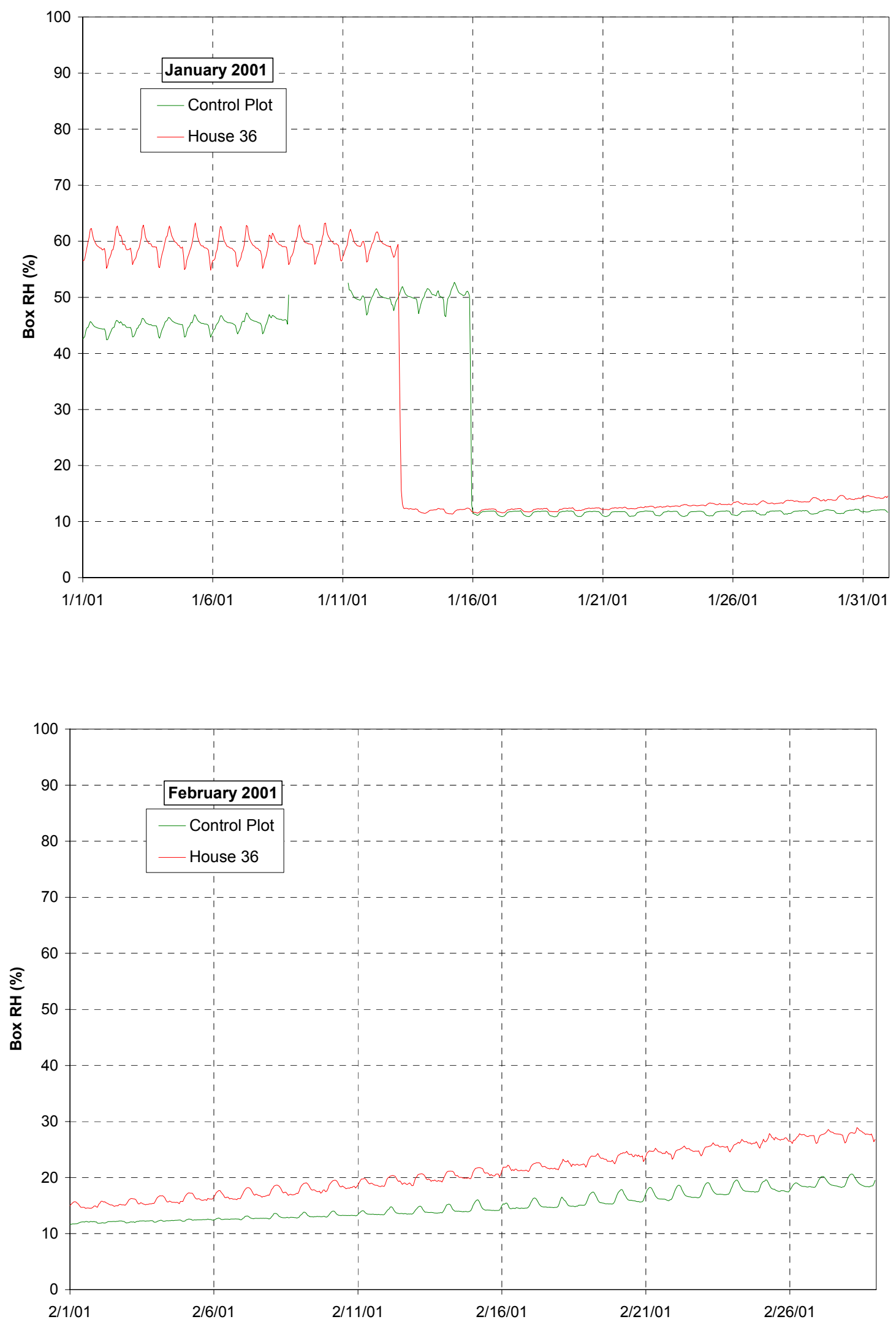

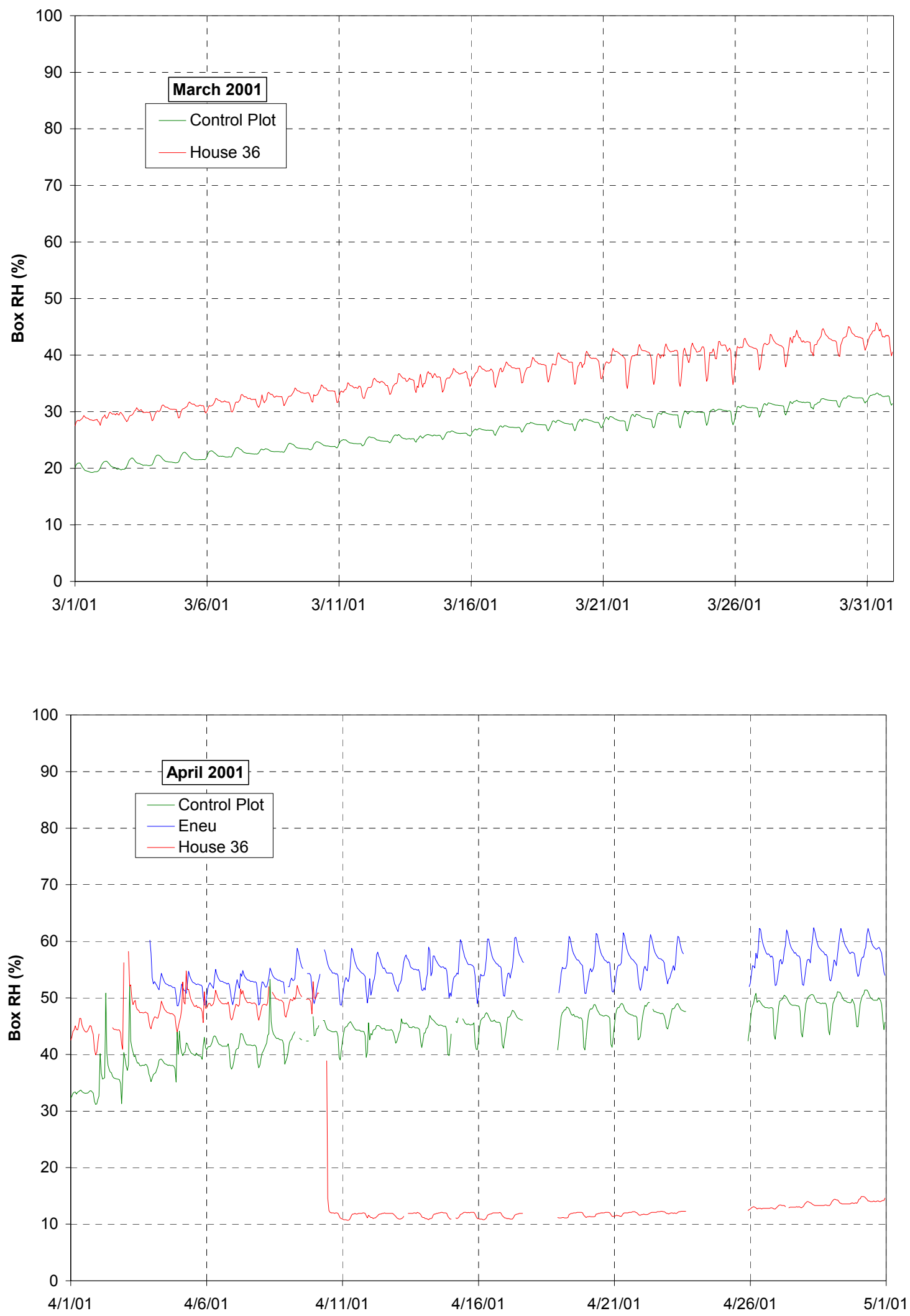


\section{F. Cumulative rainfal}
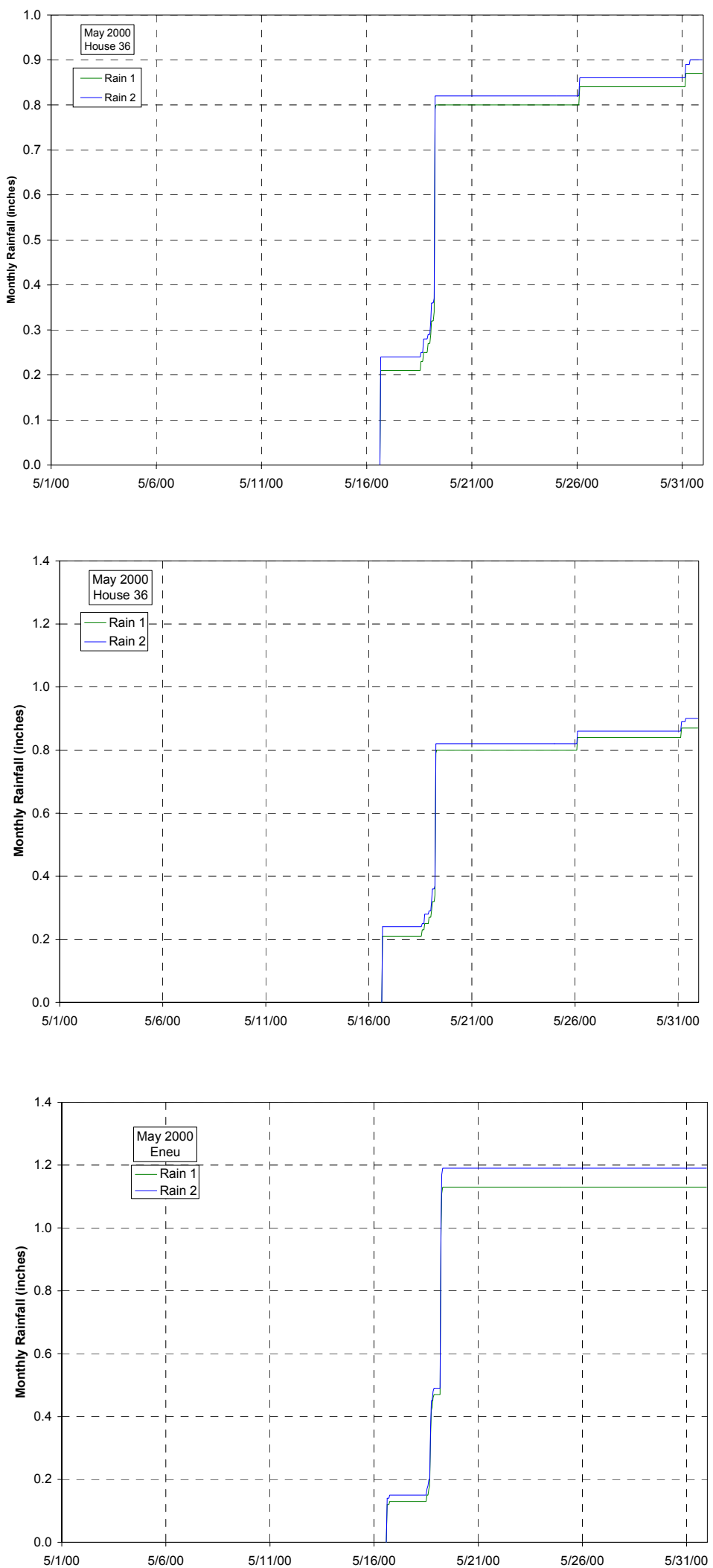

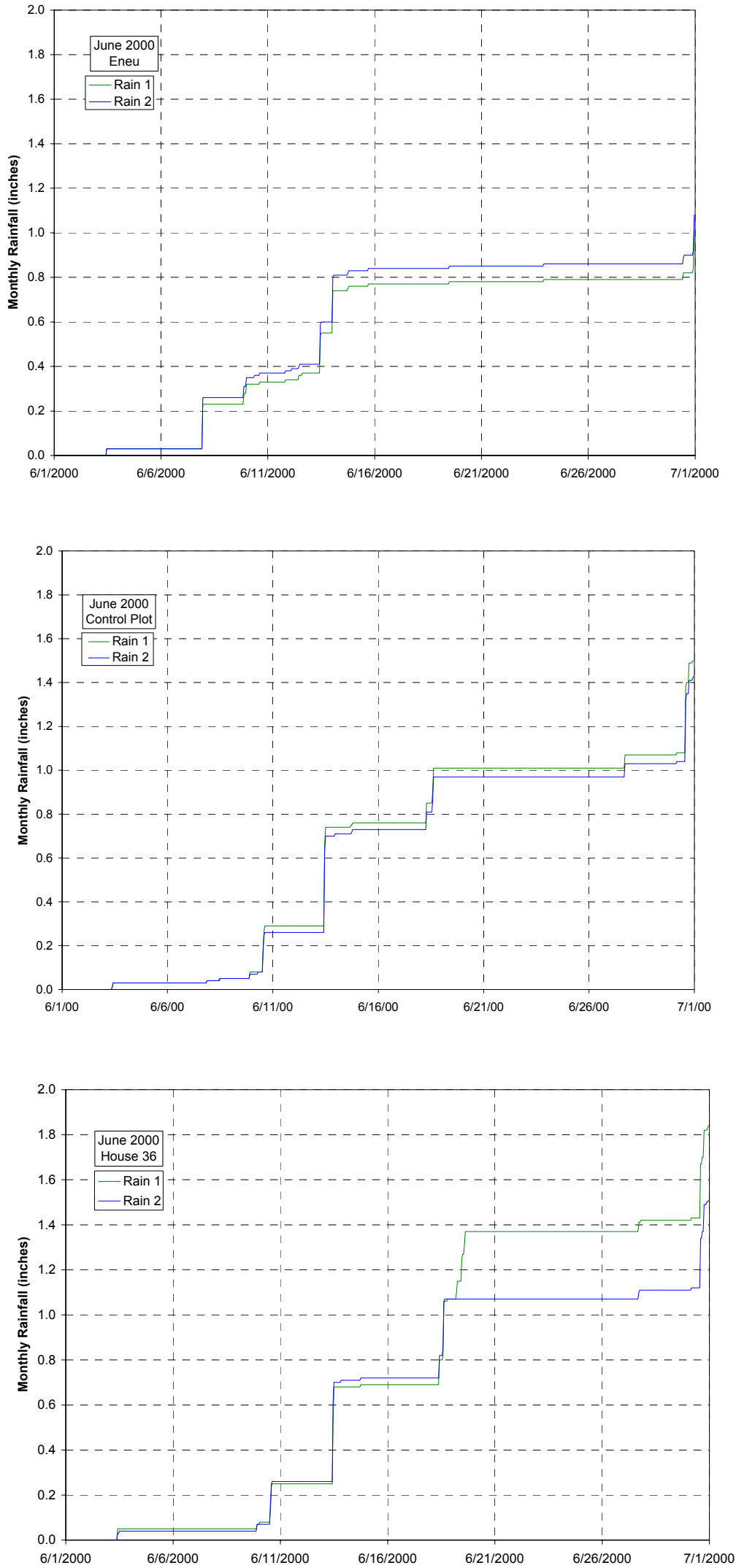

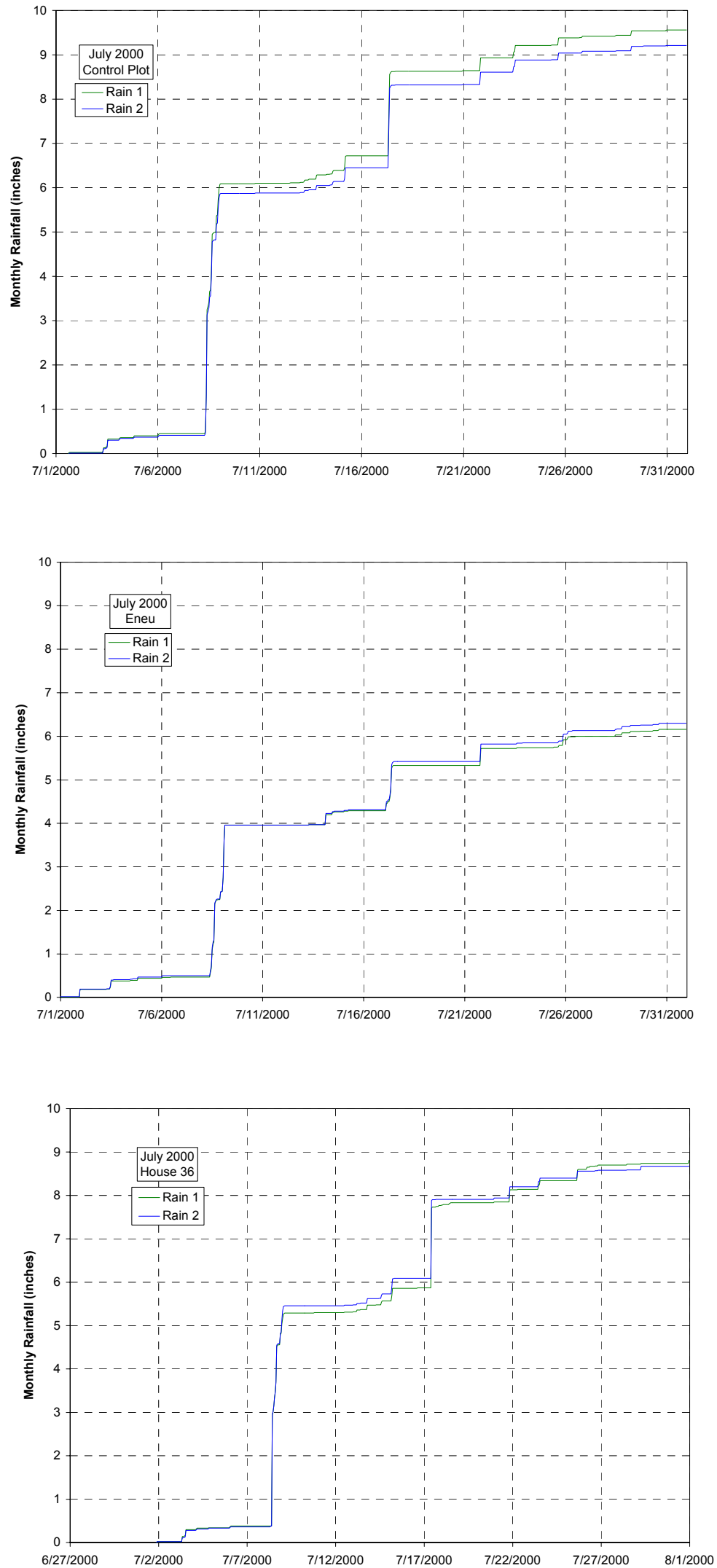

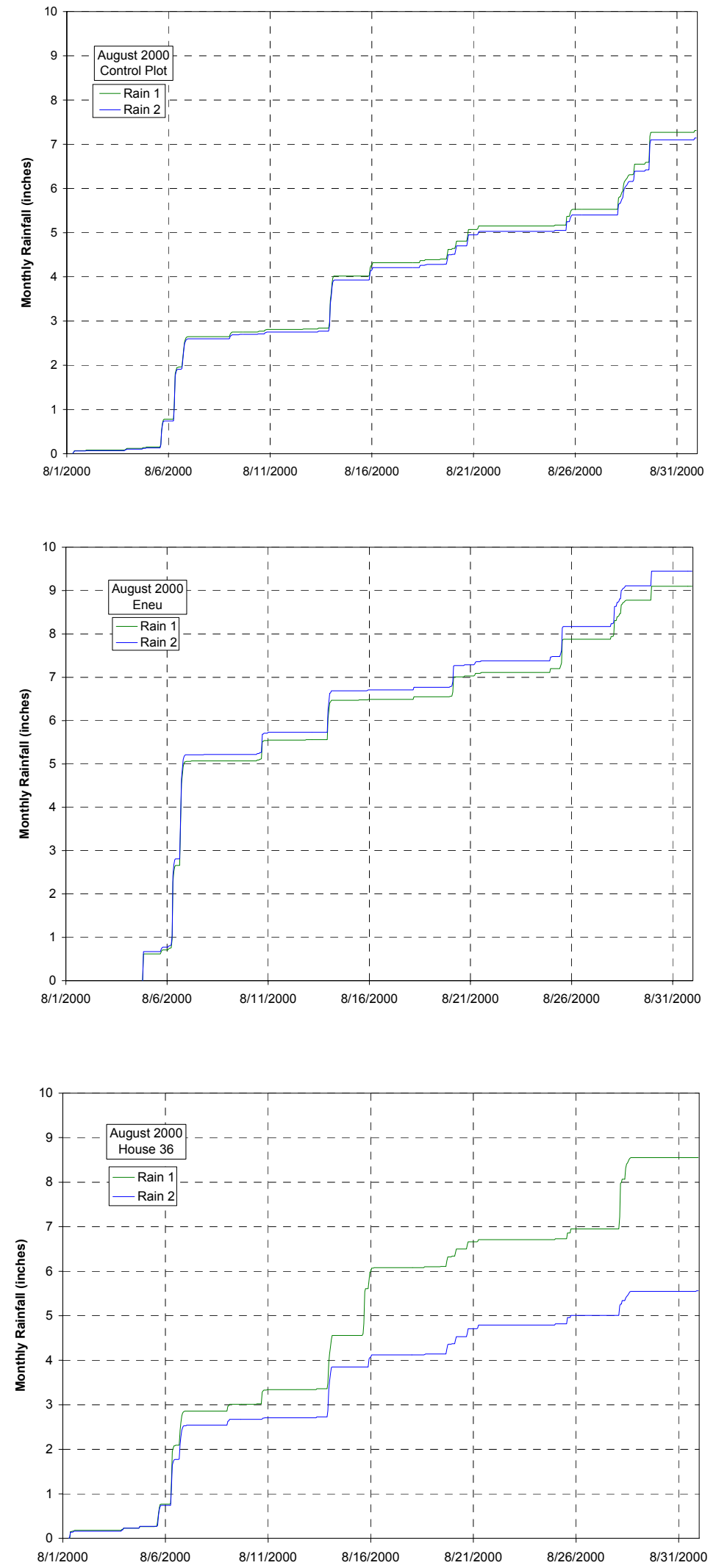

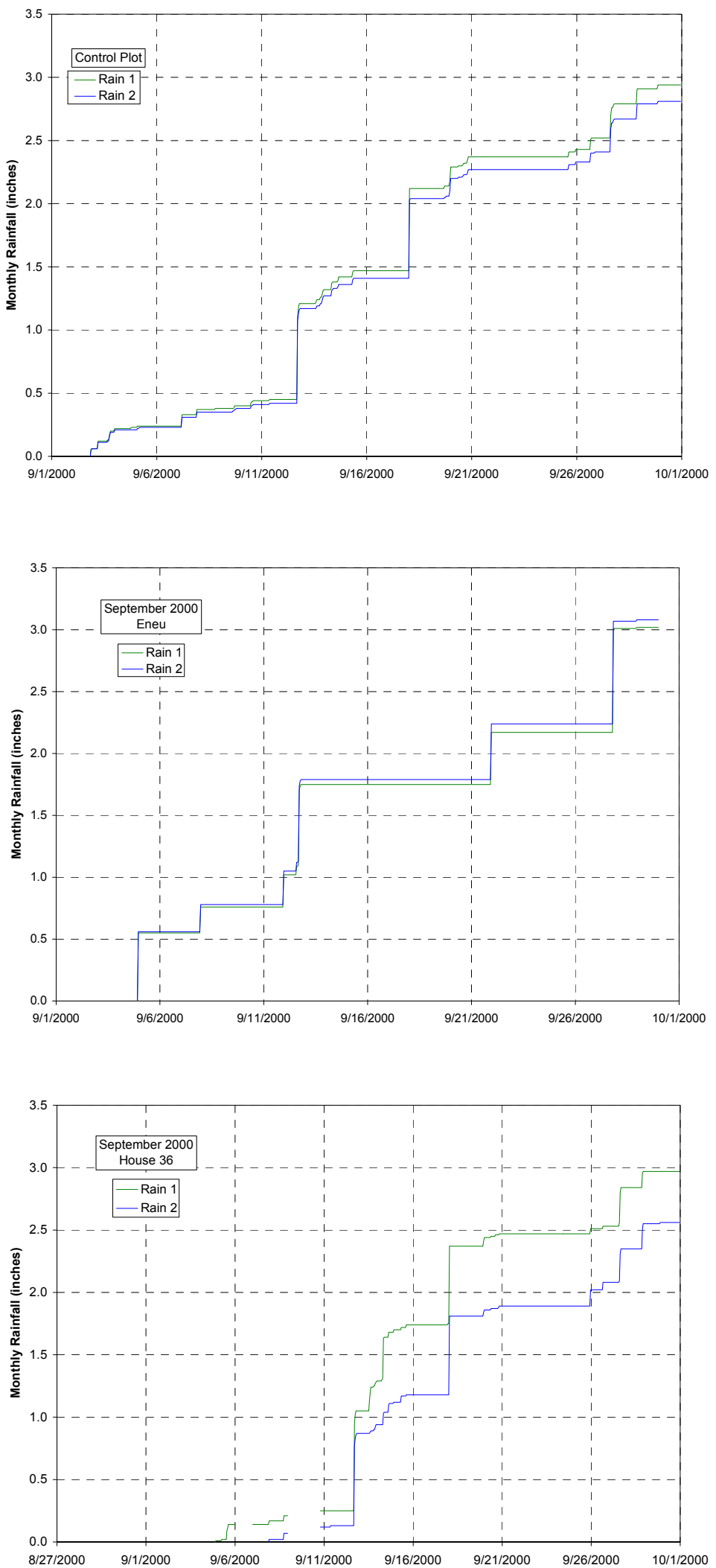

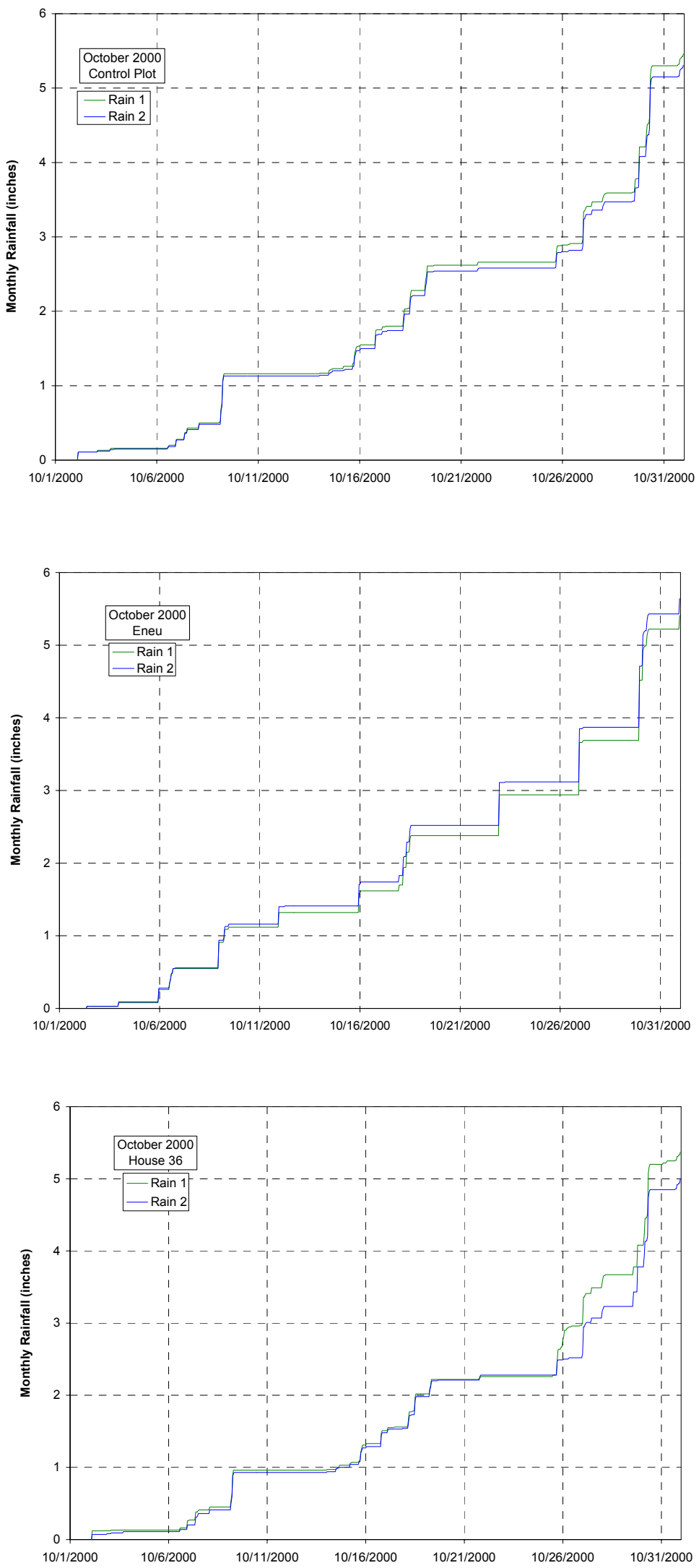

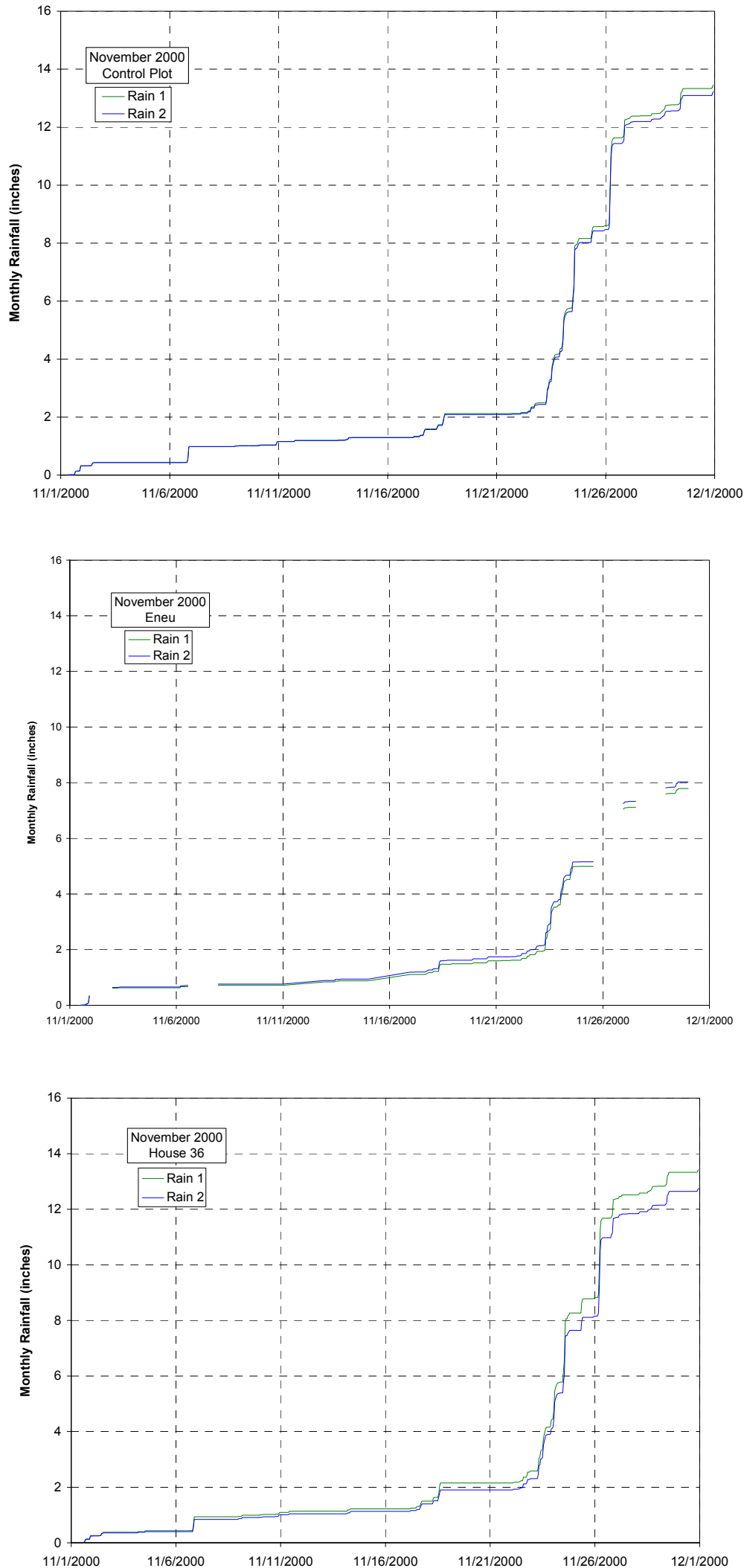

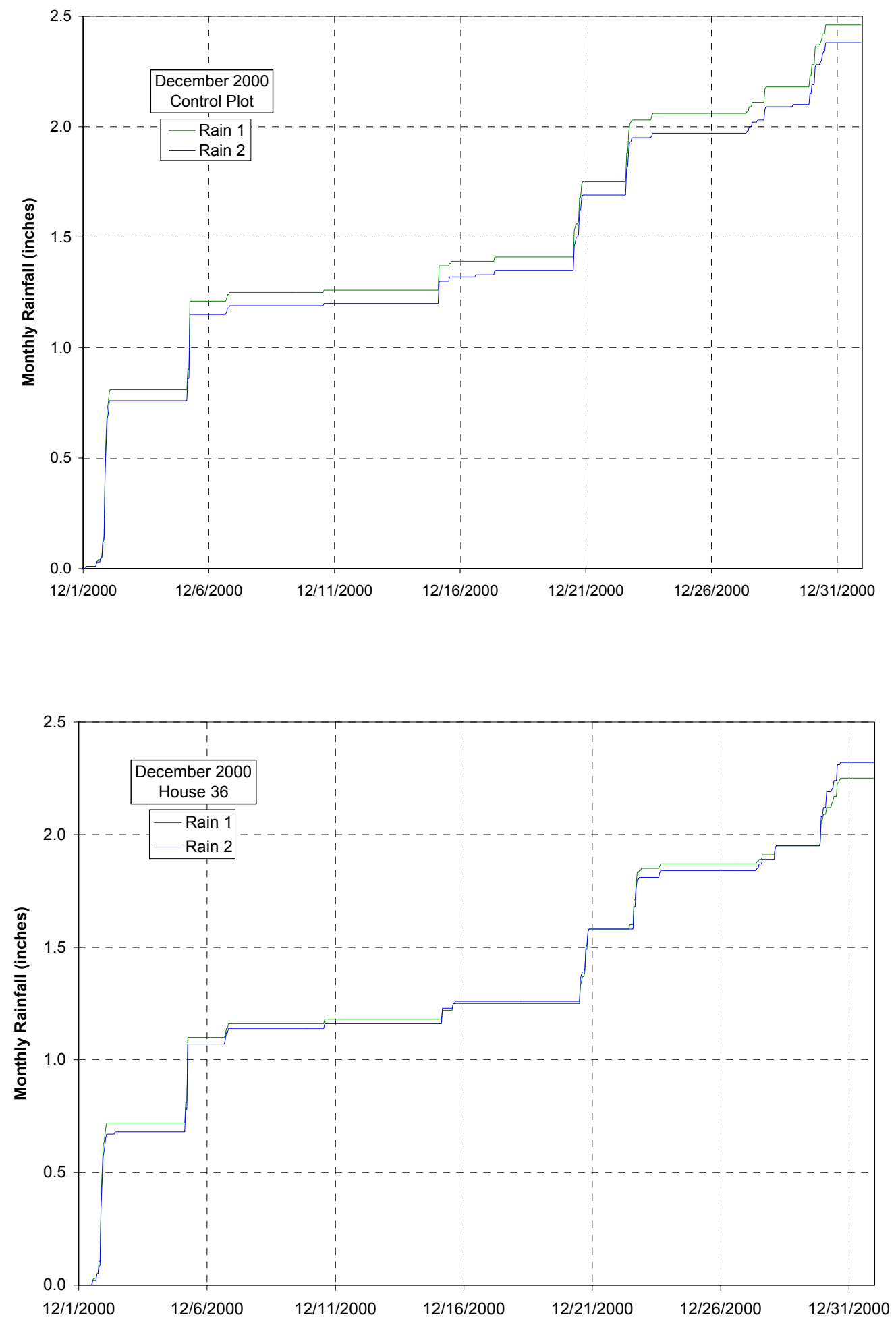

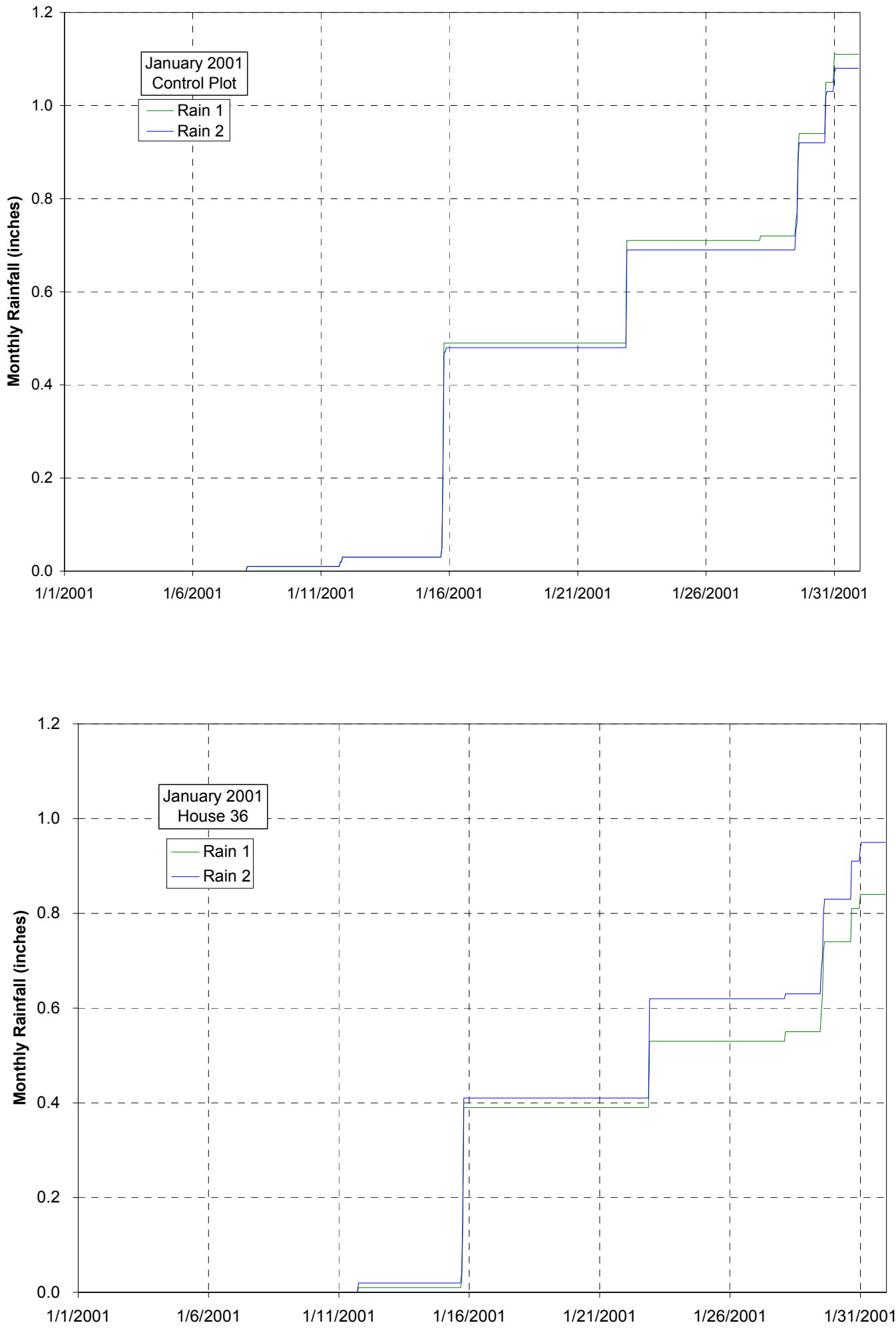

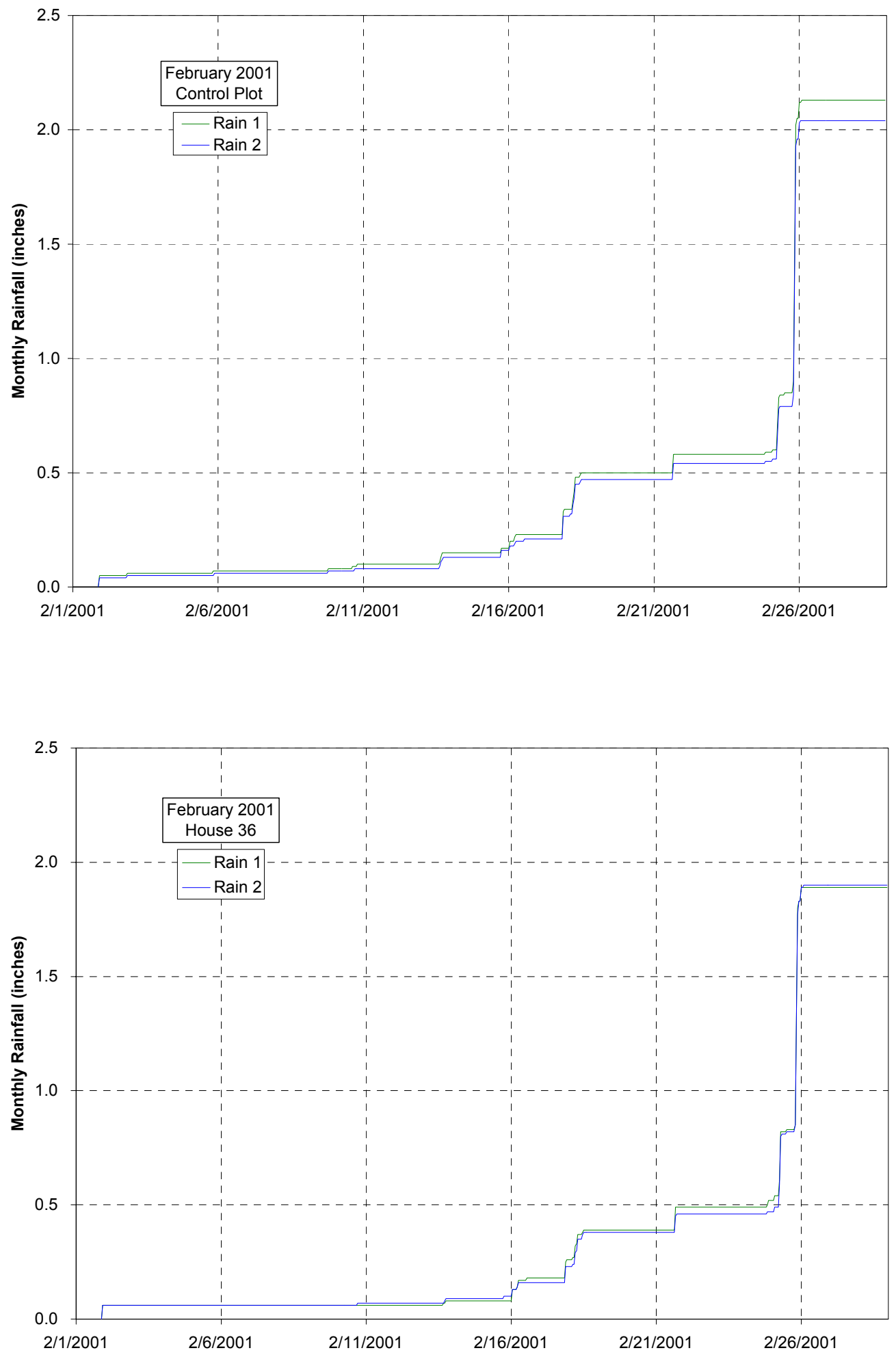

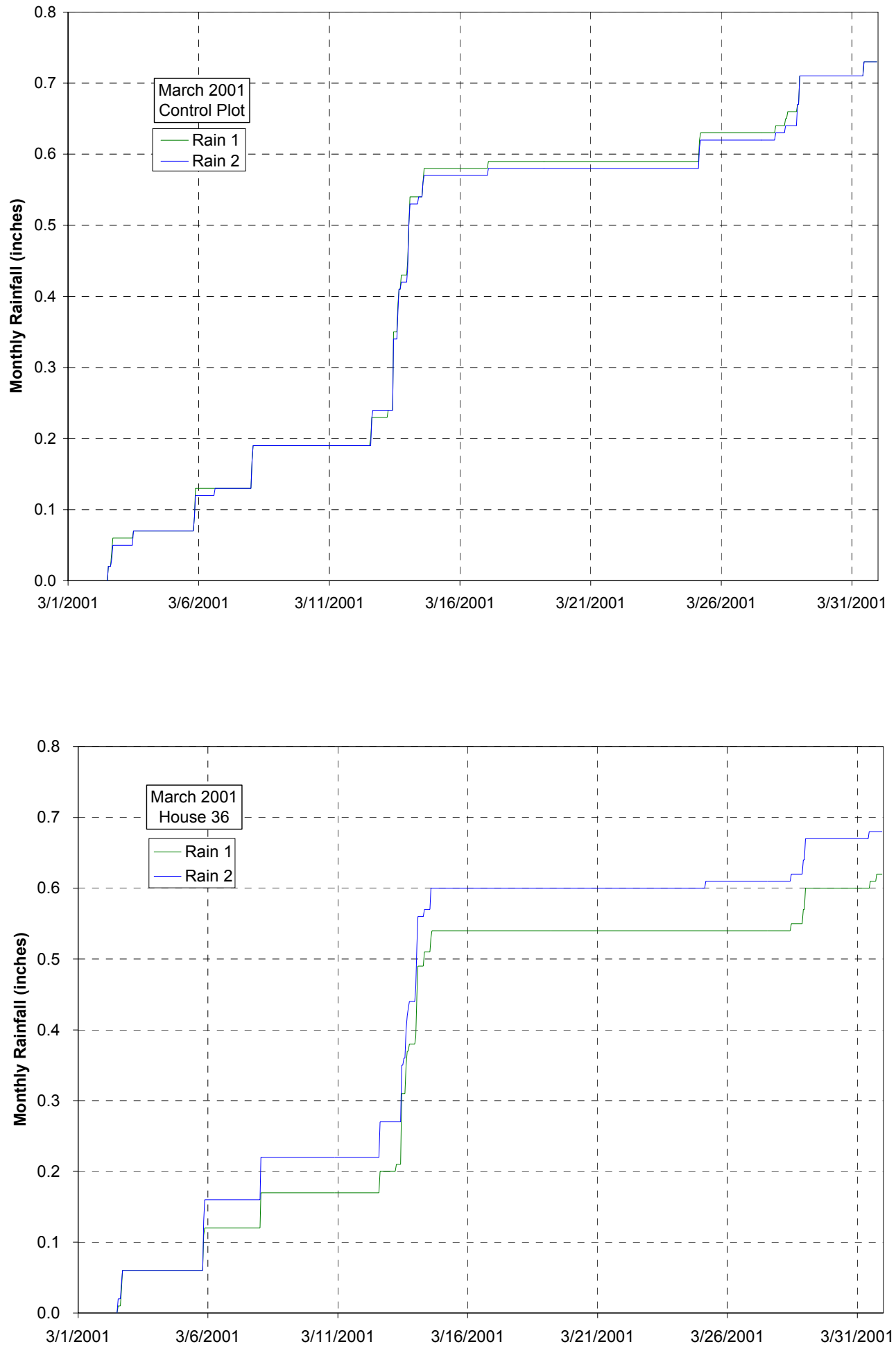

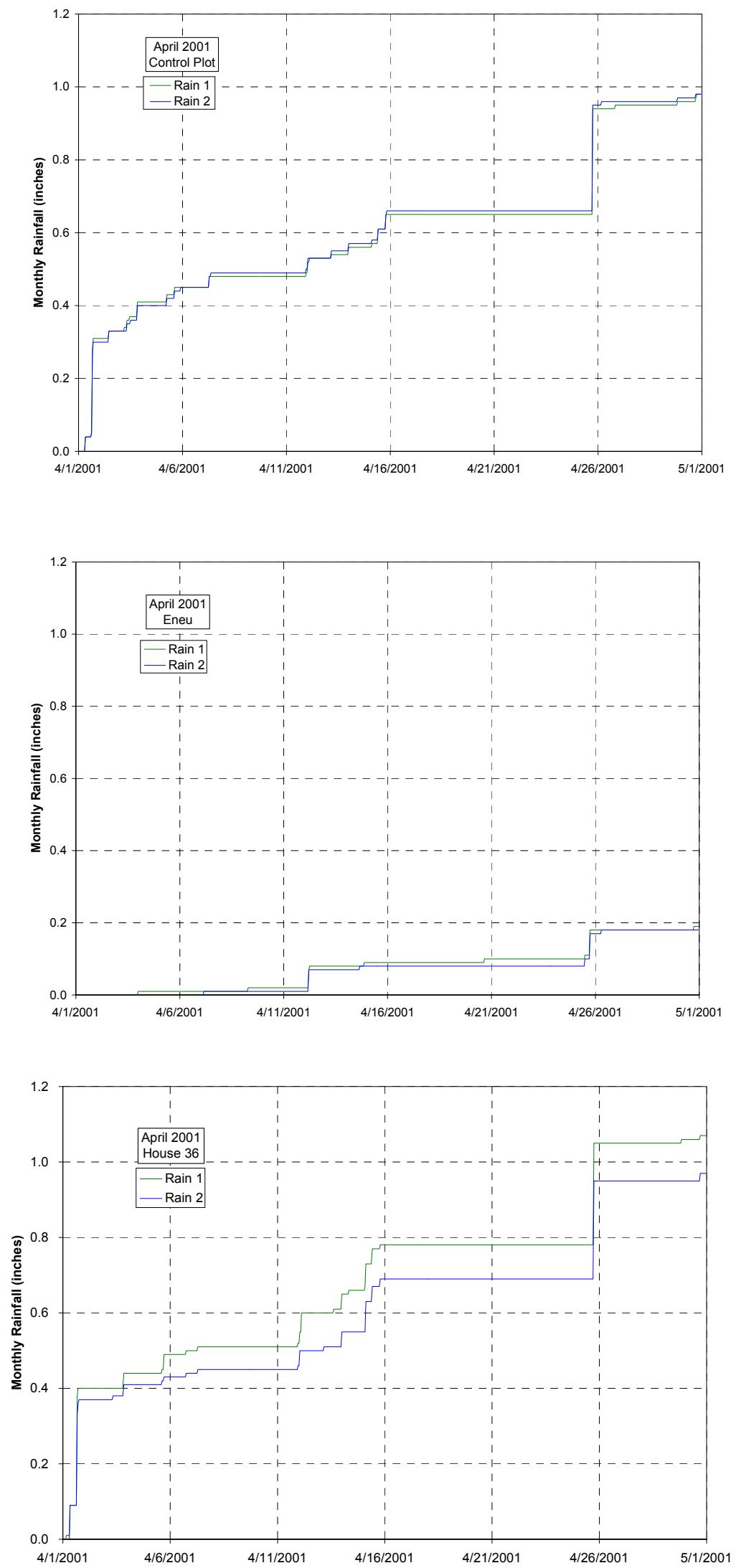
G. Incoming sunlight (Starting April 2001)

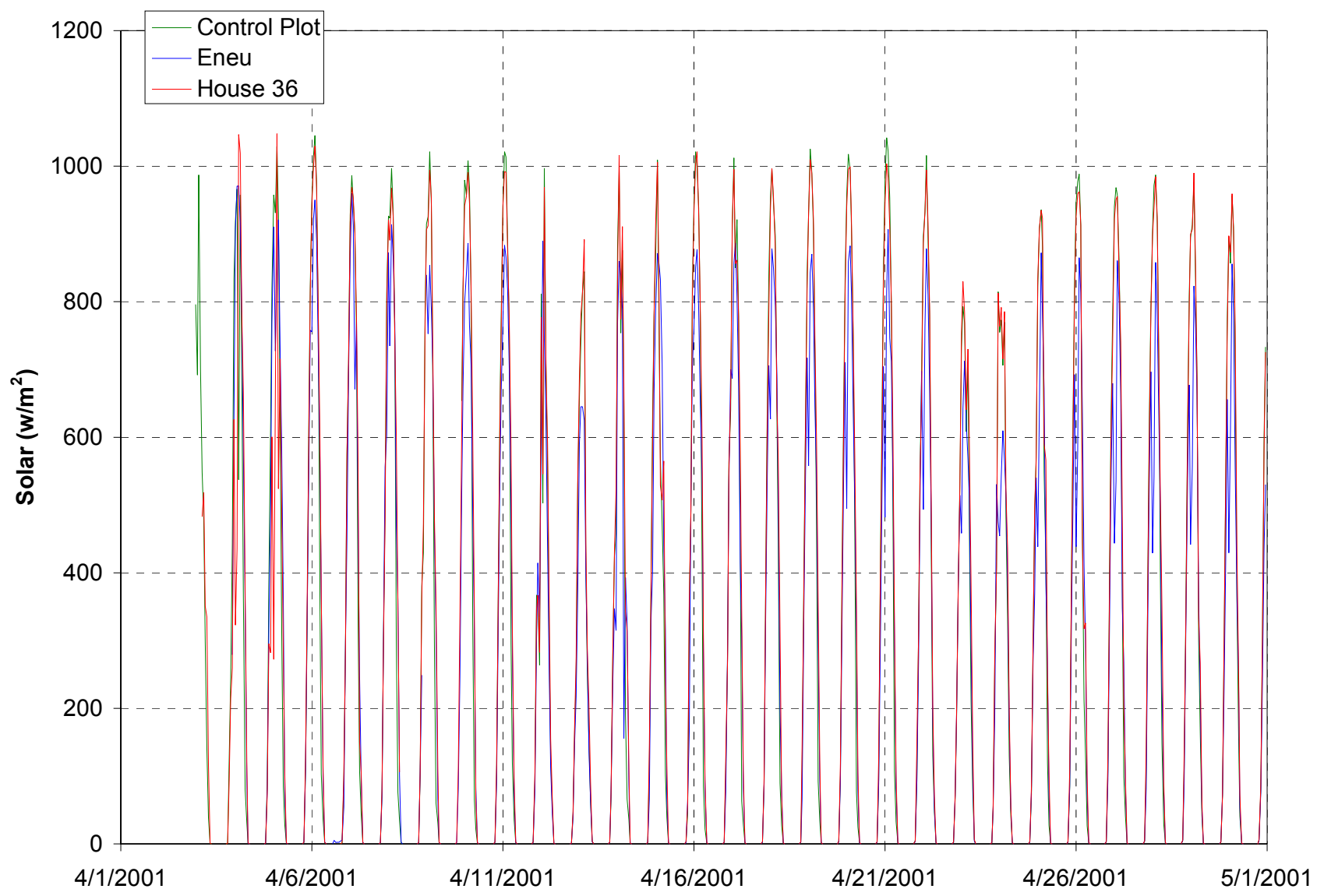


Appendix E

Monthly Tables of Daily Rainfall 
May 2000 Bikini Atoll Rain (inches)

\begin{tabular}{|c|c|c|c|c|c|c|c|c|}
\hline Date & $\begin{array}{c}\text { CP } \\
\text { South }\end{array}$ & $\begin{array}{c}\text { CP } \\
\text { North }\end{array}$ & $\begin{array}{l}\text { H36 } \\
\text { Plot }\end{array}$ & $\begin{array}{c}\text { H36 } \\
\text { Tower }\end{array}$ & $\begin{array}{l}\text { Eneu } \\
\text { West }\end{array}$ & $\begin{array}{l}\text { Eneu } \\
\text { East }\end{array}$ & $\begin{array}{c}\text { Manual } \\
\text { gage }\end{array}$ & $\begin{array}{c}\text { Bikini Isle } \\
\text { average }\end{array}$ \\
\hline $5 / 10 / 00$ & 0 & 0 & 0 & 0 & 0 & 0 & 0 & 0 \\
\hline $5 / 11 / 00$ & 0 & 0 & 0 & 0 & 0 & 0 & 0 & 0 \\
\hline $5 / 12 / 00$ & 0 & 0 & 0 & 0 & 0 & 0 & 0 & 0 \\
\hline $5 / 13 / 00$ & 0 & 0 & 0 & 0 & 0 & 0 & 0 & 0 \\
\hline $5 / 14 / 00$ & 0 & 0 & 0 & 0 & 0 & 0 & 0 & 0 \\
\hline $5 / 15 / 00$ & 0 & 0 & 0 & 0 & 0 & 0 & 0 & 0 \\
\hline $5 / 16 / 00$ & 0 & 0 & 0 & 0 & 0 & 0 & 0 & 0 \\
\hline $5 / 17 / 00$ & 0.25 & 0.25 & 0.21 & 0.24 & 0.13 & 0.15 & 0.26 & 0.24 \\
\hline $5 / 18 / 00$ & 0 & 0 & 0 & 0 & 0 & 0 & 0.01 & 0.00 \\
\hline $5 / 19 / 00$ & 0.15 & 0.14 & 0.13 & 0.13 & 0.84 & 0.87 & 0.09 & 0.13 \\
\hline $5 / 20 / 00$ & 0.48 & 0.47 & 0.46 & 0.45 & 0.16 & 0.17 & 0.60 & 0.49 \\
\hline $5 / 21 / 00$ & 0 & 0 & 0 & 0 & 0 & 0 & 0 & 0 \\
\hline $5 / 22 / 00$ & 0 & 0 & 0 & 0 & 0 & 0 & 0 & 0 \\
\hline $5 / 23 / 00$ & 0 & 0 & 0 & 0 & 0 & 0 & 0 & 0 \\
\hline $5 / 24 / 00$ & 0 & 0 & 0 & 0 & 0 & 0 & 0 & 0 \\
\hline $5 / 25 / 00$ & 0 & 0 & 0 & 0 & 0 & 0 & 0 & 0 \\
\hline $5 / 26 / 00$ & 0.06 & 0.06 & 0.04 & 0.04 & 0 & 0 & 0 & 0.04 \\
\hline $5 / 27 / 00$ & 0 & 0 & 0 & 0 & 0 & 0 & 0 & 0 \\
\hline $5 / 28 / 00$ & 0 & 0 & 0 & 0 & 0 & 0 & 0 & 0 \\
\hline $5 / 29 / 00$ & 0 & 0 & 0 & 0 & 0 & 0 & 0 & 0 \\
\hline $5 / 30 / 00$ & 0 & 0 & 0 & 0 & 0 & 0 & 0 & 0 \\
\hline $5 / 31 / 00$ & 0.03 & 0.03 & 0 & 0 & 0 & 0 & 0 & 0.01 \\
\hline $5 / 2000$ totals & 0.97 & 0.95 & 0.84 & 0.86 & 1.13 & 1.19 & 0.96 & 0.92 \\
\hline
\end{tabular}


June 2000 Bikini Atoll Rain (inches)

\begin{tabular}{|c|c|c|c|c|c|c|c|c|}
\hline Date & $\begin{array}{c}\text { CP } \\
\text { South }\end{array}$ & $\begin{array}{c}\text { CP } \\
\text { North }\end{array}$ & $\begin{array}{l}\text { H36 } \\
\text { Plot }\end{array}$ & $\begin{array}{c}\text { H36 } \\
\text { Tower }\end{array}$ & $\begin{array}{l}\text { Eneu } \\
\text { West }\end{array}$ & $\begin{array}{l}\text { Eneu } \\
\text { East }\end{array}$ & $\begin{array}{c}\text { Manual } \\
\text { gage }\end{array}$ & $\begin{array}{c}\text { Bikini Isle } \\
\text { average }\end{array}$ \\
\hline $6 / 1 / 00$ & 0.01 & 0.01 & 0.03 & 0.04 & 0 & 0 & 0 & 0.02 \\
\hline $6 / 2 / 00$ & 0 & 0 & 0 & 0 & 0 & 0 & 0 & 0 \\
\hline $6 / 3 / 00$ & 0 & 0 & 0 & 0 & 0 & 0 & 0 & 0 \\
\hline $6 / 4 / 00$ & 0.03 & 0.03 & 0.05 & 0.04 & 0.03 & 0.03 & 0 & 0.03 \\
\hline $6 / 5 / 00$ & 0 & 0 & 0 & 0 & 0 & 0 & 0 & 0 \\
\hline $6 / 6 / 00$ & 0 & 0 & 0 & 0 & 0 & 0 & 0 & 0 \\
\hline $6 / 7 / 00$ & 0 & 0 & 0 & 0 & 0 & 0 & 0 & 0 \\
\hline $6 / 8 / 00$ & 0.01 & 0.01 & 0 & 0 & 0.20 & 0.23 & 0 & 0.00 \\
\hline $6 / 9 / 00$ & 0.01 & 0.01 & 0 & 0 & 0 & 0 & 0 & 0.00 \\
\hline $6 / 10 / 00$ & 0.03 & 0.02 & 0.03 & 0.03 & 0.09 & 0.09 & 0 & 0.02 \\
\hline $6 / 11 / 00$ & 0.21 & 0.19 & 0.17 & 0.19 & 0.01 & 0.02 & 0.40 & 0.23 \\
\hline $6 / 12 / 00$ & 0 & 0 & 0 & 0 & 0.01 & 0.02 & 0 & 0 \\
\hline $6 / 13 / 00$ & 0 & 0 & 0 & 0 & 0.03 & 0.02 & 0 & 0 \\
\hline $6 / 14 / 00$ & 0.45 & 0.45 & 0.43 & 0.45 & 0.37 & 0.40 & 0.86 & 0.53 \\
\hline $6 / 15 / 00$ & 0.02 & 0.02 & 0.01 & 0.01 & 0.02 & 0.02 & 0.03 & 0.02 \\
\hline $6 / 16 / 00$ & 0 & 0 & 0 & 0 & 0.01 & 0.01 & 0 & 0 \\
\hline $6 / 17 / 00$ & 0 & 0 & 0 & 0 & 0 & 0 & 0 & 0 \\
\hline $6 / 18 / 00$ & 0 & 0 & 0 & 0 & 0 & 0 & 0 & 0 \\
\hline $6 / 19 / 00$ & 0.25 & 0.24 & 0.41 & 0.35 & 0 & 0 & 0.27 & 0.30 \\
\hline $6 / 20 / 00$ & 0 & 0 & 0.27 & 0 & 0.01 & 0.01 & 0 & 0.05 \\
\hline $6 / 21 / 00$ & 0 & 0 & 0 & 0 & 0 & 0 & 0 & 0 \\
\hline $6 / 22 / 00$ & 0 & 0 & 0 & 0 & 0 & 0 & 0 & 0 \\
\hline $6 / 23 / 00$ & 0 & 0 & 0 & 0 & 0 & 0 & 0 & 0 \\
\hline $6 / 24 / 00$ & 0 & 0 & 0 & 0 & 0.01 & 0.01 & 0 & 0 \\
\hline $6 / 25 / 00$ & 0 & 0 & 0 & 0 & 0 & 0 & 0 & 0 \\
\hline $6 / 26 / 00$ & 0 & 0 & 0 & 0 & 0 & 0 & 0 & 0 \\
\hline $6 / 27 / 00$ & 0 & 0 & 0 & 0 & 0 & 0 & 0 & 0 \\
\hline $6 / 28 / 00$ & 0.06 & 0.06 & 0.05 & 0.04 & 0 & 0 & 0.05 & 0.05 \\
\hline $6 / 29 / 00$ & 0 & 0 & 0 & 0 & 0 & 0 & 0 & 0 \\
\hline $6 / 30 / 00$ & 0.01 & 0.01 & 0.01 & 0.01 & 0 & 0 & 0 & 0.01 \\
\hline $6 / 2000$ totals & 1.08 & 1.04 & 1.43 & 1.12 & 0.79 & 0.86 & 1.61 & 1.26 \\
\hline
\end{tabular}


July 2000 Bikini Atoll Rain (inches)

\begin{tabular}{|c|c|c|c|c|c|c|c|c|}
\hline Date & $\begin{array}{c}\text { CP } \\
\text { South }\end{array}$ & $\begin{array}{c}\text { CP } \\
\text { North }\end{array}$ & $\begin{array}{l}\text { H36 } \\
\text { Plot }\end{array}$ & $\begin{array}{c}\text { H36 } \\
\text { Tower }\end{array}$ & $\begin{array}{l}\text { Eneu } \\
\text { West }\end{array}$ & $\begin{array}{l}\text { Eneu } \\
\text { East }\end{array}$ & $\begin{array}{c}\text { Manual } \\
\text { gage }\end{array}$ & $\begin{array}{c}\text { Bikini Isle } \\
\text { average }\end{array}$ \\
\hline $7 / 1 / 00$ & 0.42 & 0.39 & 0.41 & 0.39 & 0.23 & 0.24 & 0.40 & 0.40 \\
\hline $7 / 2 / 00$ & 0.03 & 0.01 & 0.02 & 0.02 & 0.17 & 0.17 & 0.05 & 0.03 \\
\hline $7 / 3 / 00$ & 0 & 0 & 0 & 0 & 0 & 0 & 0 & 0 \\
\hline $7 / 4 / 00$ & 0.33 & 0.33 & 0.31 & 0.29 & 0.20 & 0.22 & 0.33 & 0.32 \\
\hline $7 / 5 / 00$ & 0.04 & 0.03 & 0.01 & 0.02 & 0.06 & 0.06 & 0.08 & 0.04 \\
\hline $7 / 6 / 00$ & 0.05 & 0.04 & 0.04 & 0.03 & 0.02 & 0.03 & 0 & 0.03 \\
\hline $7 / 7 / 00$ & 0 & 0 & 0 & 0 & 0.01 & 0 & 0.06 & 0.01 \\
\hline $7 / 8 / 00$ & 0 & 0 & 0 & 0 & 0 & 0 & 0 & 0 \\
\hline $7 / 9 / 00$ & 5.64 & 5.46 & 4.91 & 5.10 & 3.49 & 3.46 & 4.61 & 5.14 \\
\hline $7 / 10 / 00$ & 0 & 0 & 0 & 0 & 0 & 0 & 1.10 & 0.22 \\
\hline $7 / 11 / 00$ & 0.01 & 0.01 & 0.01 & 0 & 0 & 0 & 0.03 & 0.01 \\
\hline $7 / 12 / 00$ & 0 & 0 & 0 & 0 & 0 & 0 & 0 & 0 \\
\hline $7 / 13 / 00$ & 0.07 & 0.06 & 0.06 & 0.05 & 0 & 0 & 0.02 & 0.05 \\
\hline $7 / 14 / 00$ & 0.12 & 0.11 & 0.11 & 0.11 & 0.24 & 0.27 & 0.20 & 0.13 \\
\hline $7 / 15 / 00$ & 0.42 & 0.40 & 0.39 & 0.46 & 0.08 & 0.07 & 0.10 & 0.35 \\
\hline $7 / 16 / 00$ & 0.01 & 0 & 0 & 0.01 & 0.01 & 0.01 & 0.35 & 0.07 \\
\hline $7 / 17 / 00$ & 0 & 0 & 0.01 & 0 & 0.21 & 0.23 & 0.01 & 0.00 \\
\hline $7 / 18 / 00$ & 1.91 & 1.87 & 1.92 & 1.82 & 0.83 & 0.88 & 1.80 & 1.86 \\
\hline $7 / 19 / 00$ & 0 & 0 & 0.04 & 0 & 0 & 0 & 0 & 0.01 \\
\hline $7 / 20 / 00$ & 0 & 0 & 0 & 0 & 0 & 0 & 0.01 & 0.00 \\
\hline $7 / 21 / 00$ & 0.01 & 0.01 & 0.02 & 0.03 & 0 & 0 & 0 & 0.01 \\
\hline $7 / 22 / 00$ & 0.29 & 0.28 & 0.28 & 0.26 & 0.39 & 0.40 & 0.30 & 0.28 \\
\hline $7 / 23 / 00$ & 0 & 0 & 0.01 & 0 & 0 & 0 & 0.02 & 0.01 \\
\hline $7 / 24 / 00$ & 0.28 & 0.27 & 0.20 & 0.20 & 0.02 & 0.03 & 0.29 & 0.25 \\
\hline $7 / 25 / 00$ & 0 & 0 & 0 & 0 & 0 & 0 & 0 & 0 \\
\hline $7 / 26 / 00$ & 0.17 & 0.16 & 0.31 & 0.16 & 0.25 & 0.27 & 0.17 & 0.19 \\
\hline $7 / 27 / 00$ & 0.04 & 0.04 & 0.05 & 0.02 & 0.01 & 0.01 & 0.07 & 0.04 \\
\hline $7 / 28 / 00$ & 0 & 0 & 0 & 0 & 0 & 0 & 0 & 0 \\
\hline $7 / 29 / 00$ & 0.02 & 0.01 & 0.02 & 0.01 & 0.11 & 0.12 & 0.02 & 0.02 \\
\hline $7 / 30 / 00$ & 0.10 & 0.11 & 0.02 & 0.08 & 0.01 & 0.01 & 0.12 & 0.09 \\
\hline $7 / 31 / 00$ & 0.02 & 0.01 & 0 & 0 & 0.04 & 0.04 & 0 & 0.01 \\
\hline $7 / 2000$ totals & 9.98 & 9.60 & 9.15 & 9.06 & 6.38 & 6.52 & 10.14 & 9.59 \\
\hline
\end{tabular}


August 2000 Bikini Atoll Rain (inches)

\begin{tabular}{|c|c|c|c|c|c|c|c|c|}
\hline Date & $\begin{array}{c}\text { CP } \\
\text { South }\end{array}$ & $\begin{array}{c}\text { CP } \\
\text { North }\end{array}$ & $\begin{array}{l}\text { H36 } \\
\text { Plot }\end{array}$ & $\begin{array}{c}\text { H36 } \\
\text { Tower }\end{array}$ & $\begin{array}{l}\text { Eneu } \\
\text { West }\end{array}$ & $\begin{array}{l}\text { Eneu } \\
\text { East }\end{array}$ & $\begin{array}{l}\text { Manual } \\
\text { gage }\end{array}$ & $\begin{array}{l}\text { Bikini Isle } \\
\text { average }\end{array}$ \\
\hline $8 / 1 / 00$ & 0 & 0 & 0.07 & 0.01 & 0 & 0 & 0.01 & 0.02 \\
\hline $8 / 2 / 00$ & 0.08 & 0.07 & 0.18 & 0.16 & 0 & 0 & 0.10 & 0.12 \\
\hline $8 / 3 / 00$ & 0 & 0 & 0 & 0 & 0 & 0 & 0.01 & 0.00 \\
\hline $8 / 4 / 00$ & 0.04 & 0.03 & 0.05 & 0.07 & 0 & 0 & 0 & 0.04 \\
\hline $8 / 5 / 00$ & 0.03 & 0.03 & 0.03 & 0.04 & 0.62 & 0.67 & 0.08 & 0.04 \\
\hline $8 / 6 / 00$ & 0.63 & 0.61 & $\mathrm{n} / \mathrm{a}^{*}$ & $\mathrm{n} / \mathrm{a}^{*}$ & 0.14 & 0.16 & 0.65 & 0.63 \\
\hline $8 / 7 / 00$ & 1.87 & 1.86 & $\mathrm{n} / \mathrm{a}^{*}$ & $\mathrm{n} / \mathrm{a}^{*}$ & 4.31 & 4.38 & 1.85 & 1.86 \\
\hline $8 / 8 / 00$ & 0 & 0 & $\mathrm{n} / \mathrm{a}^{*}$ & $\mathrm{n} / \mathrm{a}^{*}$ & 0 & 0.01 & 0.06 & 0.02 \\
\hline $8 / 9 / 00$ & 0.10 & 0.09 & $\mathrm{n} / \mathrm{a}^{*}$ & $\mathrm{n} / \mathrm{a}^{*}$ & 0 & 0 & 0 & 0.06 \\
\hline $8 / 10 / 00$ & 0 & 0.01 & $\mathrm{n} / \mathrm{a}^{*}$ & $\mathrm{n} / \mathrm{a}^{*}$ & 0 & 0 & 0.12 & 0.04 \\
\hline $8 / 11 / 00$ & 0.06 & 0.05 & $\mathrm{n} / \mathrm{a}^{*}$ & $\mathrm{n} / \mathrm{a}^{*}$ & 0.48 & 0.51 & 0.07 & 0.06 \\
\hline $8 / 12 / 00$ & 0 & 0 & $\mathrm{n} / \mathrm{a}^{*}$ & $\mathrm{n} / \mathrm{a}^{*}$ & 0 & 0 & 0 & 0 \\
\hline $8 / 13 / 00$ & 0.01 & 0 & $\mathrm{n} / \mathrm{a}^{*}$ & $\mathrm{n} / \mathrm{a}^{*}$ & 0.01 & 0 & 0 & 0.00 \\
\hline $8 / 14 / 00$ & 1.20 & 1.18 & $\mathrm{n} / \mathrm{a}^{*}$ & $\mathrm{n} / \mathrm{a}^{*}$ & 0.91 & 0.96 & 0.03 & 0.80 \\
\hline $8 / 15 / 00$ & 0 & 0 & $\mathrm{n} / \mathrm{a}^{*}$ & $\mathrm{n} / \mathrm{a}^{*}$ & 0 & 0 & 1.20 & 0.40 \\
\hline $8 / 16 / 00$ & 0.30 & 0.28 & $\mathrm{n} / \mathrm{a}^{*}$ & $\mathrm{n} / \mathrm{a}^{*}$ & 0.02 & 0.02 & 0 & 0.19 \\
\hline $8 / 17 / 00$ & 0 & 0 & $\mathrm{n} / \mathrm{a}^{*}$ & $\mathrm{n} / \mathrm{a}^{*}$ & 0 & 0 & 0.33 & 0.11 \\
\hline $8 / 18 / 00$ & 0 & 0 & $\mathrm{n} / \mathrm{a}^{*}$ & $\mathrm{n} / \mathrm{a}^{*}$ & 0.06 & 0.06 & 0 & 0 \\
\hline $8 / 19 / 00$ & 0.07 & 0.07 & $\mathrm{n} / \mathrm{a}^{*}$ & $\mathrm{n} / \mathrm{a}^{*}$ & 0 & 0 & 0.08 & 0.07 \\
\hline $8 / 20 / 00$ & 0.42 & 0.42 & $\mathrm{n} / \mathrm{a}^{*}$ & $\mathrm{n} / \mathrm{a}^{*}$ & 0.46 & 0.50 & 0.25 & 0.36 \\
\hline $8 / 21 / 00$ & 0.28 & 0.26 & $\mathrm{n} / \mathrm{a}^{*}$ & $\mathrm{n} / \mathrm{a}^{*}$ & 0.04 & 0.04 & 0.48 & 0.34 \\
\hline $8 / 22 / 00$ & 0.06 & 0.07 & $\mathrm{n} / \mathrm{a}^{*}$ & $\mathrm{n} / \mathrm{a}^{*}$ & 0.06 & 0.07 & 0.10 & 0.08 \\
\hline $8 / 23 / 00$ & 0 & 0 & $\mathrm{n} / \mathrm{a}^{*}$ & $\mathrm{n} / \mathrm{a}^{*}$ & 0 & 0 & 0 & 0 \\
\hline $8 / 24 / 00$ & 0 & 0 & $\mathrm{n} / \mathrm{a}^{*}$ & $\mathrm{n} / \mathrm{a}^{*}$ & 0 & 0 & 0 & 0 \\
\hline $8 / 25 / 00$ & 0.02 & 0.02 & $\mathrm{n} / \mathrm{a}^{*}$ & $\mathrm{n} / \mathrm{a}^{*}$ & 0.09 & 0.10 & 0 & 0.01 \\
\hline $8 / 26 / 00$ & 0.36 & 0.35 & $\mathrm{n} / \mathrm{a}^{*}$ & $\mathrm{n} / \mathrm{a}^{*}$ & 0.68 & 0.69 & 0.39 & 0.37 \\
\hline $8 / 27 / 00$ & 0 & 0 & $\mathrm{n} / \mathrm{a}^{*}$ & $\mathrm{n} / \mathrm{a}^{*}$ & 0 & 0 & 0.01 & 0.00 \\
\hline $8 / 28 / 00$ & 0.28 & 0.26 & $\mathrm{n} / \mathrm{a}^{*}$ & $\mathrm{n} / \mathrm{a}^{*}$ & 0.43 & 0.47 & 0 & 0.18 \\
\hline $8 / 29 / 00$ & 0.74 & 0.73 & $\mathrm{n} / \mathrm{a}^{*}$ & $\mathrm{n} / \mathrm{a}^{*}$ & 0.47 & 0.47 & 0.79 & 0.75 \\
\hline $8 / 30 / 00$ & 0.72 & 0.71 & $\mathrm{n} / \mathrm{a}^{*}$ & $\mathrm{n} / \mathrm{a}^{*}$ & 0.32 & 0.34 & 1.00 & 0.81 \\
\hline $8 / 31 / 00$ & 0 & 0 & $\mathrm{n} / \mathrm{a}^{*}$ & $\mathrm{n} / \mathrm{a}^{*}$ & 0 & 0 & 0 & 0 \\
\hline $8 / 2000$ totals & 7.27 & 7.10 & 0.33 & 0.28 & 9.10 & 9.45 & 7.61 & 7.38 \\
\hline
\end{tabular}

* Incomplete data from the House 36 station. 
September 2000 Bikini Atoll Rain (inches)

\begin{tabular}{|c|c|c|c|c|c|c|c|c|}
\hline Date & $\begin{array}{c}\text { CP } \\
\text { South }\end{array}$ & $\begin{array}{c}\text { CP } \\
\text { North }\end{array}$ & $\begin{array}{l}\text { H36 } \\
\text { Plot }\end{array}$ & $\begin{array}{c}\text { H36 } \\
\text { Tower }\end{array}$ & $\begin{array}{l}\text { Eneu } \\
\text { West }\end{array}$ & $\begin{array}{l}\text { Eneu } \\
\text { East }\end{array}$ & $\begin{array}{c}\text { Manual } \\
\text { gage }\end{array}$ & $\begin{array}{c}\text { Bikini Isle } \\
\text { average }\end{array}$ \\
\hline $9 / 1 / 00$ & 0.04 & 0.04 & $\mathrm{n} / \mathrm{a}^{*}$ & $\mathrm{n} / \mathrm{a}^{*}$ & 0 & 0 & 0 & 0.03 \\
\hline $9 / 2 / 00$ & 0 & 0 & $\mathrm{n} / \mathrm{a}^{*}$ & $\mathrm{n} / \mathrm{a}^{*}$ & 0 & 0 & 0.05 & 0.02 \\
\hline $9 / 3 / 00$ & 0.12 & 0.11 & $\mathrm{n} / \mathrm{a}^{*}$ & $\mathrm{n} / \mathrm{a}^{*}$ & 0 & 0 & 0.01 & 0.08 \\
\hline $9 / 4 / 00$ & 0.10 & 0.10 & $\mathrm{n} / \mathrm{a}^{*}$ & $\mathrm{n} / \mathrm{a}^{*}$ & 0 & 0 & 0.22 & 0.14 \\
\hline $9 / 5 / 00$ & 0.02 & 0.02 & $\mathrm{n} / \mathrm{a}^{*}$ & $\mathrm{n} / \mathrm{a}^{*}$ & 0.55 & 0.56 & 0.05 & 0.03 \\
\hline $9 / 6 / 00$ & 0 & 0 & $\mathrm{n} / \mathrm{a}^{*}$ & $\mathrm{n} / \mathrm{a}^{*}$ & 0 & 0 & 0.03 & 0.01 \\
\hline 9/7/00 & 0.09 & 0.08 & $\mathrm{n} / \mathrm{a}^{*}$ & $\mathrm{n} / \mathrm{a}^{*}$ & 0 & 0 & 0 & 0.06 \\
\hline $9 / 8 / 00$ & 0.04 & 0.04 & $\mathrm{n} / \mathrm{a}^{*}$ & $\mathrm{n} / \mathrm{a}^{*}$ & 0.21 & 0.22 & 0.10 & 0.06 \\
\hline $9 / 9 / 00$ & 0.01 & 0 & $\mathrm{n} / \mathrm{a}^{*}$ & $\mathrm{n} / \mathrm{a}^{*}$ & 0 & 0 & 0.05 & 0.02 \\
\hline $9 / 10 / 00$ & 0.02 & 0.03 & $\mathrm{n} / \mathrm{a}^{*}$ & $\mathrm{n} / \mathrm{a}^{*}$ & 0 & 0 & $\mathrm{n} / \mathrm{a}^{*}$ & 0.03 \\
\hline $9 / 11 / 00$ & 0.04 & 0.03 & 0.04 & 0.05 & 0 & 0 & 0.08 & 0.05 \\
\hline $9 / 12 / 00$ & 0.01 & 0.01 & 0 & 0.01 & 0.26 & 0.27 & 0.02 & 0.01 \\
\hline $9 / 13 / 00$ & 0.76 & 0.75 & 0.80 & 0.74 & 0.73 & 0.74 & 0.76 & 0.76 \\
\hline $9 / 14 / 00$ & 0.11 & 0.10 & 0.24 & 0.07 & 0 & 0 & 0.10 & 0.12 \\
\hline $9 / 15 / 00$ & 0.10 & 0.09 & 0.41 & 0.18 & 0 & 0 & 0.16 & 0.19 \\
\hline $9 / 16 / 00$ & 0.05 & 0.05 & 0.04 & 0.06 & 0 & 0 & 0.06 & 0.05 \\
\hline $9 / 17 / 00$ & 0 & 0 & 0 & 0 & 0 & 0 & 0 & 0 \\
\hline $9 / 18 / 00$ & 0.65 & 0.63 & 0.63 & 0.63 & 0 & 0 & 0 & 0.51 \\
\hline $9 / 19 / 00$ & 0 & 0 & 0 & 0 & 0 & 0 & 0.66 & 0.13 \\
\hline $9 / 20 / 00$ & 0.17 & 0.16 & 0.07 & 0.05 & 0 & 0 & 0.03 & 0.10 \\
\hline $9 / 21 / 00$ & 0.08 & 0.07 & 0.03 & 0.03 & 0 & 0 & 0.25 & 0.09 \\
\hline $9 / 22 / 00$ & 0 & 0 & 0 & 0 & 0.42 & 0.45 & 0.01 & 0.00 \\
\hline $9 / 23 / 00$ & 0 & 0 & 0 & 0 & 0 & 0 & 0 & 0 \\
\hline $9 / 24 / 00$ & 0 & 0 & 0 & 0 & 0 & 0 & 0 & 0 \\
\hline $9 / 25 / 00$ & 0 & 0 & 0 & 0 & 0 & 0 & 0 & 0 \\
\hline $9 / 26 / 00$ & 0.06 & 0.06 & 0.04 & 0.13 & 0 & 0 & 0.05 & 0.07 \\
\hline $9 / 27 / 00$ & 0.09 & 0.08 & 0.02 & 0.06 & 0 & 0 & 0.12 & 0.07 \\
\hline $9 / 28 / 00$ & 0.27 & 0.26 & 0.31 & 0.27 & 0.84 & 0.83 & 0.29 & 0.28 \\
\hline $9 / 29 / 00$ & 0.12 & 0.12 & 0.13 & 0.20 & 0.01 & 0.01 & 0.01 & 0.12 \\
\hline $9 / 30 / 00$ & 0.03 & 0.02 & 0 & 0.01 & 0 & 0 & 0.13 & 0.04 \\
\hline $9 / 2000$ totals & 2.98 & 2.85 & 2.76 & 2.49 & 3.02 & 3.08 & 3.24 & 3.06 \\
\hline
\end{tabular}

* Incomplete data from the House 36 station. 
October 2000 Bikini Atoll Rain (inches)

\begin{tabular}{|c|c|c|c|c|c|c|c|c|}
\hline Date & $\begin{array}{c}\text { CP } \\
\text { South }\end{array}$ & $\begin{array}{c}\text { CP } \\
\text { North }\end{array}$ & $\begin{array}{l}\text { H36 } \\
\text { Plot }\end{array}$ & $\begin{array}{c}\text { H36 } \\
\text { Tower }\end{array}$ & $\begin{array}{l}\text { Eneu } \\
\text { West }\end{array}$ & $\begin{array}{l}\text { Eneu } \\
\text { East }\end{array}$ & $\begin{array}{l}\text { Manual } \\
\text { gage }\end{array}$ & $\begin{array}{c}\text { Bikini Isle } \\
\text { average }\end{array}$ \\
\hline $10 / 1 / 00$ & 0 & 0 & 0 & 0 & 0.09 & 0.09 & 0.04 & 0.01 \\
\hline $10 / 2 / 00$ & 0.11 & 0.11 & 0.12 & 0.07 & 0 & 0 & 0 & 0.08 \\
\hline $10 / 3 / 00$ & 0.02 & 0.01 & 0.01 & 0.02 & 0.03 & 0.03 & 0.12 & 0.04 \\
\hline $10 / 4 / 00$ & 0.03 & 0.03 & 0 & 0.02 & 0.05 & 0.06 & 0.05 & 0.03 \\
\hline $10 / 5 / 00$ & 0 & 0 & 0 & 0 & 0 & 0 & 0 & 0 \\
\hline $10 / 6 / 00$ & 0 & 0 & 0 & 0 & 0.18 & 0.19 & 0 & 0 \\
\hline $10 / 7 / 00$ & 0.12 & 0.12 & 0.14 & 0.09 & 0.29 & 0.28 & 0 & 0.09 \\
\hline $10 / 8 / 00$ & 0.22 & 0.21 & 0.18 & 0.21 & 0 & 0 & 0.34 & 0.23 \\
\hline $10 / 9 / 00$ & 0.26 & 0.24 & 0.18 & 0.18 & 0.39 & 0.41 & 0.08 & 0.19 \\
\hline $10 / 10 / 00$ & 0.40 & 0.41 & 0.33 & 0.34 & 0.18 & 0.19 & 0.67 & 0.43 \\
\hline $10 / 11 / 00$ & 0 & 0 & 0 & 0 & 0 & 0 & 0 & 0 \\
\hline $10 / 12 / 00$ & 0 & 0 & 0 & 0 & 0.20 & 0.24 & 0 & 0 \\
\hline $10 / 13 / 00$ & 0 & 0 & 0 & 0 & 0 & 0.01 & 0 & 0 \\
\hline $10 / 14 / 00$ & 0.01 & 0.01 & 0.01 & 0.01 & 0 & 0 & 0.01 & 0.01 \\
\hline $10 / 15 / 00$ & 0.09 & 0.07 & 0.09 & 0.10 & 0 & 0 & 0 & 0.07 \\
\hline $10 / 16 / 00$ & 0.29 & 0.29 & 0.27 & 0.25 & 0.30 & 0.33 & 0.40 & 0.30 \\
\hline $10 / 17 / 00$ & 0.24 & 0.23 & 0.22 & 0.24 & 0 & 0 & 0.23 & 0.23 \\
\hline $10 / 18 / 00$ & 0.24 & 0.23 & 0.22 & 0.19 & 0.32 & 0.35 & 0.07 & 0.19 \\
\hline $10 / 19 / 00$ & 0.25 & 0.25 & 0.25 & 0.26 & 0.44 & 0.43 & 0.49 & 0.30 \\
\hline $10 / 20 / 00$ & 0.34 & 0.33 & 0.20 & 0.23 & 0 & 0 & 0.34 & 0.29 \\
\hline $10 / 21 / 00$ & 0 & 0 & 0 & 0 & 0 & 0 & 0 & 0 \\
\hline $10 / 22 / 00$ & 0.04 & 0.04 & 0.04 & 0.07 & 0 & 0 & 0.05 & 0.05 \\
\hline $10 / 23 / 00$ & 0 & 0 & 0 & 0 & 0.56 & 0.59 & 0 & 0 \\
\hline $10 / 24 / 00$ & 0 & 0 & 0 & 0 & 0 & 0.01 & 0 & 0 \\
\hline $10 / 25 / 00$ & 0 & 0 & 0 & 0 & 0 & 0 & 0 & 0 \\
\hline $10 / 26 / 00$ & 0.23 & 0.22 & 0.67 & 0.22 & 0 & 0 & 0.22 & 0.31 \\
\hline $10 / 27 / 00$ & 0.52 & 0.50 & 0.48 & 0.51 & 0.75 & 0.75 & 0.03 & 0.41 \\
\hline $10 / 28 / 00$ & 0.18 & 0.17 & 0.26 & 0.22 & 0 & 0 & 0.58 & 0.28 \\
\hline $10 / 29 / 00$ & 0 & 0 & 0 & 0 & 0 & 0 & 0 & 0 \\
\hline $10 / 30 / 00$ & 0.93 & 0.90 & 0.79 & 0.91 & 1.29 & 1.32 & 0.77 & 0.86 \\
\hline $10 / 31 / 00$ & 0.78 & 0.78 & 0.76 & 0.71 & 0.24 & 0.24 & 1.09 & 0.82 \\
\hline $10 / 2000$ totals & 5.30 & 5.15 & 5.22 & 4.85 & 5.31 & 5.52 & 5.58 & 5.22 \\
\hline
\end{tabular}


November 2000 Bikini Atoll Rain (inches)

\begin{tabular}{|c|c|c|c|c|c|c|c|c|}
\hline Date & $\begin{array}{c}\text { CP } \\
\text { South }\end{array}$ & $\begin{array}{c}\text { CP } \\
\text { North }\end{array}$ & $\begin{array}{l}\text { H36 } \\
\text { Plot }\end{array}$ & $\begin{array}{c}\text { H36 } \\
\text { Tower }\end{array}$ & $\begin{array}{l}\text { Eneu } \\
\text { West }\end{array}$ & $\begin{array}{l}\text { Eneu } \\
\text { East }\end{array}$ & $\begin{array}{c}\text { Manual } \\
\text { gage }\end{array}$ & $\begin{array}{c}\text { Bikini Isle } \\
\text { average }\end{array}$ \\
\hline $11 / 1 / 00$ & 0.16 & 0.16 & 0.17 & 0.15 & 0.19 & 0.21 & 0.11 & 0.15 \\
\hline $11 / 2 / 00$ & 0.32 & 0.32 & 0.25 & 0.25 & 0.34 & 0.34 & 0.24 & 0.28 \\
\hline $11 / 3 / 00$ & 0.11 & 0.11 & 0.13 & 0.11 & 0.28 & 0.30 & 0.31 & 0.15 \\
\hline $11 / 4 / 00$ & 0 & 0 & 0.02 & 0.02 & 0.01 & 0.02 & 0 & 0.01 \\
\hline $11 / 5 / 00$ & 0 & 0 & 0.03 & 0.02 & 0 & 0 & 0.01 & 0.01 \\
\hline $11 / 6 / 00$ & 0 & 0 & 0 & 0 & 0.04 & 0.04 & 0 & 0 \\
\hline $11 / 7 / 00$ & 0.55 & 0.55 & 0.51 & 0.44 & 0 & 0.01 & 0.15 & 0.44 \\
\hline $11 / 8 / 00$ & 0 & 0 & 0 & 0 & 0.05 & 0.05 & 0.40 & 0.08 \\
\hline $11 / 9 / 00$ & 0.04 & 0.03 & 0.05 & 0.07 & 0 & 0 & 0 & 0.04 \\
\hline $11 / 10 / 00$ & 0.02 & 0.02 & 0.03 & 0.03 & 0 & 0 & 0.05 & 0.03 \\
\hline $11 / 11 / 00$ & 0.12 & 0.12 & 0.07 & 0.07 & 0 & 0 & 0.04 & 0.08 \\
\hline $11 / 12 / 00$ & 0.04 & 0.04 & 0.05 & 0.03 & 0 & 0 & 0.19 & 0.07 \\
\hline $11 / 13 / 00$ & 0 & 0 & 0 & 0 & 0.12 & 0.13 & 0.01 & 0.00 \\
\hline $11 / 14 / 00$ & 0.09 & 0.09 & 0.04 & 0.04 & 0.04 & 0.05 & 0.01 & 0.05 \\
\hline $11 / 15 / 00$ & 0.01 & 0.01 & 0.04 & 0.05 & 0 & 0 & 0.10 & 0.04 \\
\hline $11 / 16 / 00$ & 0 & 0 & 0 & 0 & 0 & 0 & 0.01 & 0.00 \\
\hline $11 / 17 / 00$ & 0.04 & 0.03 & 0.03 & 0.03 & 0.23 & 0.26 & $\mathrm{n} / \mathrm{a}^{\mathrm{a}}$ & 0.03 \\
\hline $11 / 18 / 00$ & 0.25 & 0.25 & 0.25 & 0.24 & 0.11 & 0.12 & 0.30 & 0.26 \\
\hline $11 / 19 / 00$ & 0.53 & 0.52 & 0.85 & 0.63 & 0.27 & 0.30 & 0.55 & 0.62 \\
\hline $11 / 20 / 00$ & 0 & 0 & 0 & 0 & 0.04 & 0.05 & 0.03 & 0.01 \\
\hline $11 / 21 / 00$ & 0 & 0 & 0 & 0 & 0.07 & 0.07 & 0.01 & 0.00 \\
\hline $11 / 22 / 00$ & 0.04 & 0.04 & 0.03 & 0.03 & 0.09 & 0.12 & 0.02 & 0.03 \\
\hline $11 / 23 / 00$ & 0.33 & 0.31 & 0.40 & 0.38 & 0.26 & 0.29 & 0.37 & 0.36 \\
\hline $11 / 24 / 00$ & 3.22 & 3.16 & 3.16 & 3.04 & 2.51 & 2.47 & 1.75 & 2.87 \\
\hline $11 / 25 / 00$ & 2.45 & 2.42 & 2.53 & 2.29 & 0.54 & 0.54 & 4.15 & 2.77 \\
\hline $11 / 26 / 00$ & 1.67 & 1.65 & 1.68 & 1.64 & 0 & 0 & 0.42 & 1.41 \\
\hline $11 / 27 / 00$ & 2.55 & 2.51 & 2.51 & 2.52 & 2.12 & 2.17 & 3.95 & 2.81 \\
\hline $11 / 28 / 00$ & 0.09 & 0.10 & 0.12 & 0.11 & 0 & 0 & 0.16 & 0.12 \\
\hline $11 / 29 / 00$ & 0.30 & 0.28 & 0.25 & 0.24 & 0.49 & 0.51 & 0.40 & 0.29 \\
\hline $11 / 30 / 00$ & 0.56 & 0.53 & 0.50 & 0.49 & $\mathrm{n} / \mathrm{a}^{\mathrm{b}}$ & $\mathrm{n} / \mathrm{a}^{\mathrm{b}}$ & 0.57 & 0.53 \\
\hline $11 / 2000$ totals & 13.49 & 13.25 & 13.70 & 12.92 & 7.98 & 8.24 & 14.31 & 13.54 \\
\hline
\end{tabular}

a Manual gauge rainfall noted on 11/18/00 (0.30") includes rain occurring on 11/17/00.

b Incomplete data from the Eneu station. 
December 2000 Bikini Atoll Rain (inches)

\begin{tabular}{|c|c|c|c|c|c|c|c|c|}
\hline Date & $\begin{array}{c}\text { CP } \\
\text { South }\end{array}$ & $\begin{array}{c}\text { CP } \\
\text { North }\end{array}$ & $\begin{array}{l}\text { H36 } \\
\text { Plot }\end{array}$ & $\begin{array}{c}\text { H36 } \\
\text { Tower }\end{array}$ & $\begin{array}{l}\text { Eneu } \\
\text { West }\end{array}$ & $\begin{array}{l}\text { Eneu } \\
\text { East }\end{array}$ & $\begin{array}{l}\text { Manual } \\
\text { gage }\end{array}$ & $\begin{array}{c}\text { Bikini Isle } \\
\text { average }\end{array}$ \\
\hline $12 / 1 / 00$ & 0.14 & 0.15 & 0.09 & 0.11 & $\mathrm{n} / \mathrm{a}^{*}$ & $\mathrm{n} / \mathrm{a}^{*}$ & 0.02 & 0.10 \\
\hline $12 / 2 / 00$ & 0.80 & 0.75 & 0.72 & 0.67 & $\mathrm{n} / \mathrm{a}^{*}$ & $\mathrm{n} / \mathrm{a}^{*}$ & 0.30 & 0.65 \\
\hline $12 / 3 / 00$ & 0 & 0 & 0 & 0.01 & $\mathrm{n} / \mathrm{a}^{*}$ & $\mathrm{n} / \mathrm{a}^{*}$ & 0.66 & 0.13 \\
\hline $12 / 4 / 00$ & 0 & 0 & 0 & 0 & $\mathrm{n} / \mathrm{a}^{*}$ & $\mathrm{n} / \mathrm{a}^{*}$ & 0 & 0 \\
\hline $12 / 5 / 00$ & 0.09 & 0.10 & 0.09 & 0.10 & $\mathrm{n} / \mathrm{a}^{*}$ & $\mathrm{n} / \mathrm{a}^{*}$ & 0 & 0.08 \\
\hline $12 / 6 / 00$ & 0.31 & 0.29 & 0.29 & 0.29 & $\mathrm{n} / \mathrm{a}^{*}$ & $\mathrm{n} / \mathrm{a}^{*}$ & 0.40 & 0.32 \\
\hline $12 / 7 / 00$ & 0.04 & 0.04 & 0.06 & 0.07 & $\mathrm{n} / \mathrm{a}^{*}$ & $\mathrm{n} / \mathrm{a}^{*}$ & 0.06 & 0.05 \\
\hline $12 / 8 / 00$ & 0 & 0 & 0 & 0 & $\mathrm{n} / \mathrm{a}^{*}$ & $\mathrm{n} / \mathrm{a}^{*}$ & 0 & 0 \\
\hline $12 / 9 / 00$ & 0 & 0 & 0 & 0 & $\mathrm{n} / \mathrm{a}^{*}$ & $\mathrm{n} / \mathrm{a}^{*}$ & 0 & 0 \\
\hline $12 / 10 / 00$ & 0 & 0 & 0 & 0 & $\mathrm{n} / \mathrm{a}^{*}$ & $\mathrm{n} / \mathrm{a}^{*}$ & 0 & 0 \\
\hline $12 / 11 / 00$ & 0.01 & 0.01 & 0.02 & 0.02 & $\mathrm{n} / \mathrm{a}^{*}$ & $\mathrm{n} / \mathrm{a}^{*}$ & 0.02 & 0.02 \\
\hline $12 / 12 / 00$ & 0 & 0 & 0 & 0 & $\mathrm{n} / \mathrm{a}^{*}$ & $\mathrm{n} / \mathrm{a}^{*}$ & 0 & 0 \\
\hline $12 / 13 / 00$ & 0 & 0 & 0 & 0 & $\mathrm{n} / \mathrm{a}^{*}$ & $\mathrm{n} / \mathrm{a}^{*}$ & 0 & 0 \\
\hline $12 / 14 / 00$ & 0 & 0 & 0 & 0 & $\mathrm{n} / \mathrm{a}^{*}$ & $\mathrm{n} / \mathrm{a}^{*}$ & 0 & 0 \\
\hline $12 / 15 / 00$ & 0.11 & 0.10 & 0.04 & 0.07 & $\mathrm{n} / \mathrm{a}^{*}$ & $\mathrm{n} / \mathrm{a}^{*}$ & 0.02 & 0.07 \\
\hline $12 / 16 / 00$ & 0.02 & 0.02 & 0.03 & 0.03 & $\mathrm{n} / \mathrm{a}^{*}$ & $\mathrm{n} / \mathrm{a}^{*}$ & 0.15 & 0.05 \\
\hline $12 / 17 / 00$ & 0 & 0.01 & 0 & 0 & $\mathrm{n} / \mathrm{a}^{*}$ & $\mathrm{n} / \mathrm{a}^{*}$ & 0.02 & 0.01 \\
\hline $12 / 18 / 00$ & 0.02 & 0.02 & 0 & 0 & $\mathrm{n} / \mathrm{a}^{*}$ & $\mathrm{n} / \mathrm{a}^{*}$ & 0.02 & 0.01 \\
\hline $12 / 19 / 00$ & 0 & 0 & 0 & 0 & $\mathrm{n} / \mathrm{a}^{*}$ & $\mathrm{n} / \mathrm{a}^{*}$ & 0 & 0 \\
\hline $12 / 20 / 00$ & 0 & 0 & 0 & 0 & $\mathrm{n} / \mathrm{a}^{*}$ & $\mathrm{n} / \mathrm{a}^{*}$ & 0 & 0 \\
\hline $12 / 21 / 00$ & 0.34 & 0.34 & 0.33 & 0.32 & $\mathrm{n} / \mathrm{a}^{*}$ & $\mathrm{n} / \mathrm{a}^{*}$ & 0.40 & 0.35 \\
\hline $12 / 22 / 00$ & 0 & 0 & 0 & 0 & $\mathrm{n} / \mathrm{a}^{*}$ & $\mathrm{n} / \mathrm{a}^{*}$ & 0.01 & 0.00 \\
\hline $12 / 23 / 00$ & 0.28 & 0.26 & 0.27 & 0.23 & $\mathrm{n} / \mathrm{a}^{*}$ & $\mathrm{n} / \mathrm{a}^{*}$ & 0.30 & 0.27 \\
\hline $12 / 24 / 00$ & 0.03 & 0.02 & 0.02 & 0.03 & $\mathrm{n} / \mathrm{a}^{*}$ & $\mathrm{n} / \mathrm{a}^{*}$ & 0.07 & 0.03 \\
\hline $12 / 25 / 00$ & 0 & 0 & 0 & 0 & $\mathrm{n} / \mathrm{a}^{*}$ & $\mathrm{n} / \mathrm{a}^{*}$ & 0 & 0 \\
\hline $12 / 26 / 00$ & 0 & 0 & 0 & 0 & $\mathrm{n} / \mathrm{a}^{*}$ & $\mathrm{n} / \mathrm{a}^{*}$ & 0 & 0 \\
\hline $12 / 27 / 00$ & 0 & 0 & 0 & 0 & $\mathrm{n} / \mathrm{a}^{*}$ & $\mathrm{n} / \mathrm{a}^{*}$ & 0 & 0 \\
\hline $12 / 28 / 00$ & 0.12 & 0.12 & 0.08 & 0.11 & $\mathrm{n} / \mathrm{a}^{*}$ & $\mathrm{n} / \mathrm{a}^{*}$ & 0.07 & 0.10 \\
\hline $12 / 29 / 00$ & 0 & 0 & 0 & 0 & $\mathrm{n} / \mathrm{a}^{*}$ & $\mathrm{n} / \mathrm{a}^{*}$ & 0.10 & 0.02 \\
\hline $12 / 30 / 00$ & 0.19 & 0.19 & 0.17 & 0.24 & $\mathrm{n} / \mathrm{a}^{*}$ & $\mathrm{n} / \mathrm{a}^{*}$ & 0.01 & 0.16 \\
\hline $12 / 31 / 00$ & 0.09 & 0.10 & 0.13 & 0.13 & $\mathrm{n} / \mathrm{a}^{*}$ & $\mathrm{n} / \mathrm{a}^{*}$ & 0.34 & 0.16 \\
\hline $12 / 2000$ totals & 2.59 & 2.52 & 2.34 & 2.43 & $\mathrm{n} / \mathrm{a}^{*}$ & $\mathrm{n} / \mathrm{a}^{*}$ & 2.97 & 2.57 \\
\hline
\end{tabular}

* Incomplete data from the Eneu station. 
January 2001 Bikini Atoll Rain (inches)

\begin{tabular}{|c|c|c|c|c|c|c|c|c|}
\hline Date & $\begin{array}{c}\text { CP } \\
\text { South }\end{array}$ & $\begin{array}{c}\text { CP } \\
\text { North }\end{array}$ & $\begin{array}{l}\text { H36 } \\
\text { Plot }\end{array}$ & $\begin{array}{c}\text { H36 } \\
\text { Tower }\end{array}$ & $\begin{array}{l}\text { Eneu } \\
\text { West }\end{array}$ & $\begin{array}{l}\text { Eneu } \\
\text { East }\end{array}$ & $\begin{array}{l}\text { Manual } \\
\text { gage }\end{array}$ & $\begin{array}{c}\text { Bikini Isle } \\
\text { average }\end{array}$ \\
\hline $1 / 1 / 01$ & 0 & 0 & 0 & 0 & $\mathrm{n} / \mathrm{a}^{*}$ & $\mathrm{n} / \mathrm{a}^{*}$ & 0 & 0 \\
\hline $1 / 2 / 01$ & 0 & 0 & 0 & 0 & $\mathrm{n} / \mathrm{a}^{*}$ & $\mathrm{n} / \mathrm{a}^{*}$ & 0 & 0 \\
\hline $1 / 3 / 01$ & 0 & 0 & 0 & 0 & $\mathrm{n} / \mathrm{a}^{*}$ & $\mathrm{n} / \mathrm{a}^{*}$ & 0.01 & 0.00 \\
\hline $1 / 4 / 01$ & 0 & 0 & 0 & 0 & $\mathrm{n} / \mathrm{a}^{*}$ & $\mathrm{n} / \mathrm{a}^{*}$ & 0 & 0 \\
\hline $1 / 5 / 01$ & 0 & 0 & 0 & 0 & $\mathrm{n} / \mathrm{a}^{*}$ & $\mathrm{n} / \mathrm{a}^{*}$ & 0 & 0 \\
\hline $1 / 6 / 01$ & 0 & 0 & 0 & 0 & $\mathrm{n} / \mathrm{a}^{*}$ & $\mathrm{n} / \mathrm{a}^{*}$ & 0 & 0 \\
\hline $1 / 7 / 01$ & 0 & 0 & 0 & 0 & $\mathrm{n} / \mathrm{a}^{*}$ & $\mathrm{n} / \mathrm{a}^{*}$ & 0 & 0 \\
\hline $1 / 8 / 01$ & 0.01 & 0.01 & 0 & 0 & $\mathrm{n} / \mathrm{a}^{*}$ & $\mathrm{n} / \mathrm{a}^{*}$ & 0 & 0.00 \\
\hline $1 / 9 / 01$ & 0 & 0 & 0 & 0 & $\mathrm{n} / \mathrm{a}^{*}$ & $\mathrm{n} / \mathrm{a}^{*}$ & 0.02 & 0.00 \\
\hline $1 / 10 / 01$ & 0 & 0 & 0 & 0 & $\mathrm{n} / \mathrm{a}^{*}$ & $\mathrm{n} / \mathrm{a}^{*}$ & 0 & 0 \\
\hline $1 / 11 / 01$ & 0 & 0 & 0 & 0 & $\mathrm{n} / \mathrm{a}^{*}$ & $\mathrm{n} / \mathrm{a}^{*}$ & 0 & 0 \\
\hline $1 / 12 / 01$ & 0.02 & 0.02 & 0.01 & 0.02 & $\mathrm{n} / \mathrm{a}^{*}$ & $\mathrm{n} / \mathrm{a}^{*}$ & 0.05 & 0.02 \\
\hline $1 / 13 / 01$ & 0 & 0 & 0 & 0 & $\mathrm{n} / \mathrm{a}^{*}$ & $\mathrm{n} / \mathrm{a}^{*}$ & 0.01 & 0.00 \\
\hline $1 / 14 / 01$ & 0 & 0 & 0 & 0 & $\mathrm{n} / \mathrm{a}^{*}$ & $\mathrm{n} / \mathrm{a}^{*}$ & 0 & 0 \\
\hline $1 / 15 / 01$ & 0 & 0 & 0 & 0 & $\mathrm{n} / \mathrm{a}^{*}$ & $\mathrm{n} / \mathrm{a}^{*}$ & 0.01 & 0.00 \\
\hline $1 / 16 / 01$ & 0.46 & 0.45 & 0.38 & 0.39 & $\mathrm{n} / \mathrm{a}^{*}$ & $\mathrm{n} / \mathrm{a}^{*}$ & 0.47 & 0.43 \\
\hline $1 / 17 / 01$ & 0 & 0 & 0 & 0 & $\mathrm{n} / \mathrm{a}^{*}$ & $\mathrm{n} / \mathrm{a}^{*}$ & 0.01 & 0.00 \\
\hline $1 / 18 / 01$ & 0 & 0 & 0 & 0 & $\mathrm{n} / \mathrm{a}^{*}$ & $\mathrm{n} / \mathrm{a}^{*}$ & 0 & 0 \\
\hline $1 / 19 / 01$ & 0 & 0 & 0 & 0 & $\mathrm{n} / \mathrm{a}^{*}$ & $\mathrm{n} / \mathrm{a}^{*}$ & 0 & 0 \\
\hline $1 / 20 / 01$ & 0 & 0 & 0 & 0 & $\mathrm{n} / \mathrm{a}^{*}$ & $\mathrm{n} / \mathrm{a}^{*}$ & 0.01 & 0.00 \\
\hline $1 / 21 / 01$ & 0 & 0 & 0 & 0 & $\mathrm{n} / \mathrm{a}^{*}$ & $\mathrm{n} / \mathrm{a}^{*}$ & 0 & 0 \\
\hline $1 / 22 / 01$ & 0 & 0 & 0 & 0 & $\mathrm{n} / \mathrm{a}^{*}$ & $\mathrm{n} / \mathrm{a}^{*}$ & 0 & 0 \\
\hline $1 / 23 / 01$ & 0.22 & 0.21 & 0.14 & 0.21 & $\mathrm{n} / \mathrm{a}^{*}$ & $\mathrm{n} / \mathrm{a}^{*}$ & 0 & 0.16 \\
\hline $1 / 24 / 01$ & 0 & 0 & 0 & 0 & $\mathrm{n} / \mathrm{a}^{*}$ & $\mathrm{n} / \mathrm{a}^{*}$ & 0.22 & 0.04 \\
\hline $1 / 25 / 01$ & 0 & 0 & 0 & 0 & $\mathrm{n} / \mathrm{a}^{*}$ & $\mathrm{n} / \mathrm{a}^{*}$ & 0 & 0 \\
\hline $1 / 26 / 01$ & 0 & 0 & 0 & 0 & $\mathrm{n} / \mathrm{a}^{*}$ & $\mathrm{n} / \mathrm{a}^{*}$ & 0 & 0 \\
\hline $1 / 27 / 01$ & 0 & 0 & 0 & 0 & $\mathrm{n} / \mathrm{a}^{*}$ & $\mathrm{n} / \mathrm{a}^{*}$ & 0 & 0 \\
\hline $1 / 28 / 01$ & 0.01 & 0 & 0.02 & 0.01 & $\mathrm{n} / \mathrm{a}^{*}$ & $\mathrm{n} / \mathrm{a}^{*}$ & 0 & 0.01 \\
\hline $1 / 29 / 01$ & 0 & 0 & 0 & 0 & $\mathrm{n} / \mathrm{a}^{*}$ & $\mathrm{n} / \mathrm{a}^{*}$ & 0.02 & 0.00 \\
\hline $1 / 30 / 01$ & 0.22 & 0.23 & 0.19 & 0.20 & $\mathrm{n} / \mathrm{a}^{*}$ & $\mathrm{n} / \mathrm{a}^{*}$ & 0.15 & 0.20 \\
\hline $1 / 31 / 01$ & 0.17 & 0.16 & 0.10 & 0.12 & $\mathrm{n} / \mathrm{a}^{*}$ & $\mathrm{n} / \mathrm{a}^{*}$ & 0.12 & 0.13 \\
\hline $1 / 2001$ totals & 1.11 & 1.08 & 0.84 & 0.95 & $\mathrm{n} / \mathrm{a}^{*}$ & $\mathrm{n} / \mathrm{a}^{*}$ & 1.10 & 1.02 \\
\hline
\end{tabular}

* Incomplete data from the Eneu station. 
February 2001 Bikini Atoll Rain (inches)

\begin{tabular}{|c|c|c|c|c|c|c|c|c|}
\hline Date & $\begin{array}{c}\text { CP } \\
\text { South }\end{array}$ & $\begin{array}{c}\text { CP } \\
\text { North }\end{array}$ & $\begin{array}{l}\text { H36 } \\
\text { Plot }\end{array}$ & $\begin{array}{c}\text { H36 } \\
\text { Tower }\end{array}$ & $\begin{array}{l}\text { Eneu } \\
\text { West }\end{array}$ & $\begin{array}{l}\text { Eneu } \\
\text { East }\end{array}$ & $\begin{array}{c}\text { Manual } \\
\text { gage }\end{array}$ & $\begin{array}{c}\text { Bikini Isle } \\
\text { average }\end{array}$ \\
\hline $2 / 1 / 01$ & 0 & 0 & 0 & 0 & $\mathrm{n} / \mathrm{a}^{*}$ & $\mathrm{n} / \mathrm{a}^{*}$ & 0.06 & 0.01 \\
\hline $2 / 2 / 01$ & 0.05 & 0.04 & 0.06 & 0.06 & $\mathrm{n} / \mathrm{a}^{*}$ & $\mathrm{n} / \mathrm{a} *$ & 0.01 & 0.04 \\
\hline $2 / 3 / 01$ & 0.01 & 0.01 & 0 & 0 & $\mathrm{n} / \mathrm{a}^{*}$ & $\mathrm{n} / \mathrm{a}^{*}$ & 0.06 & 0.02 \\
\hline $2 / 4 / 01$ & 0 & 0 & 0 & 0 & $\mathrm{n} / \mathrm{a}^{*}$ & $\mathrm{n} / \mathrm{a}^{*}$ & 0.01 & 0.00 \\
\hline $2 / 5 / 01$ & 0 & 0 & 0 & 0 & $\mathrm{n} / \mathrm{a}^{*}$ & $\mathrm{n} / \mathrm{a}^{*}$ & 0 & 0 \\
\hline $2 / 6 / 01$ & 0.01 & 0.01 & 0 & 0 & $\mathrm{n} / \mathrm{a}^{*}$ & $\mathrm{n} / \mathrm{a}^{*}$ & 0.01 & 0.01 \\
\hline $2 / 7 / 01$ & 0 & 0 & 0 & 0 & $\mathrm{n} / \mathrm{a}^{*}$ & $\mathrm{n} / \mathrm{a}^{*}$ & 0 & 0 \\
\hline $2 / 8 / 01$ & 0 & 0 & 0 & 0 & $\mathrm{n} / \mathrm{a}^{*}$ & $\mathrm{n} / \mathrm{a}^{*}$ & 0 & 0 \\
\hline $2 / 9 / 01$ & 0 & 0 & 0 & 0 & $\mathrm{n} / \mathrm{a}^{*}$ & $\mathrm{n} / \mathrm{a}^{*}$ & 0 & 0 \\
\hline $2 / 10 / 01$ & 0.01 & 0.01 & 0 & 0 & $\mathrm{n} / \mathrm{a}^{*}$ & $\mathrm{n} / \mathrm{a}^{*}$ & 0.02 & 0.01 \\
\hline $2 / 11 / 01$ & 0.02 & 0.01 & 0 & 0.01 & $\mathrm{n} / \mathrm{a}^{*}$ & $\mathrm{n} / \mathrm{a}^{*}$ & 0.01 & 0.01 \\
\hline $2 / 12 / 01$ & 0 & 0 & 0 & 0 & $\mathrm{n} / \mathrm{a}^{*}$ & $\mathrm{n} / \mathrm{a}^{*}$ & 0 & 0 \\
\hline $2 / 13 / 01$ & 0 & 0 & 0 & 0 & $\mathrm{n} / \mathrm{a}^{*}$ & $\mathrm{n} / \mathrm{a}^{*}$ & 0 & 0 \\
\hline $2 / 14 / 01$ & 0.05 & 0.05 & 0.02 & 0.02 & $\mathrm{n} / \mathrm{a}^{*}$ & $\mathrm{n} / \mathrm{a}^{*}$ & 0.05 & 0.04 \\
\hline $2 / 15 / 01$ & 0 & 0 & 0 & 0 & $\mathrm{n} / \mathrm{a}^{*}$ & $\mathrm{n} / \mathrm{a}^{*}$ & 0 & 0 \\
\hline $2 / 16 / 01$ & 0.07 & 0.06 & 0.06 & 0.05 & $\mathrm{n} / \mathrm{a}^{*}$ & $\mathrm{n} / \mathrm{a}^{*}$ & 0.03 & 0.05 \\
\hline $2 / 17 / 01$ & 0.01 & 0.02 & 0.04 & 0.02 & $\mathrm{n} / \mathrm{a}^{*}$ & $\mathrm{n} / \mathrm{a}^{*}$ & 0.07 & 0.03 \\
\hline $2 / 18 / 01$ & 0.15 & 0.15 & 0.14 & 0.13 & $\mathrm{n} / \mathrm{a}^{*}$ & $\mathrm{n} / \mathrm{a}^{*}$ & 0 & 0.11 \\
\hline $2 / 19 / 01$ & 0.12 & 0.11 & 0.07 & 0.09 & $\mathrm{n} / \mathrm{a}^{*}$ & $\mathrm{n} / \mathrm{a}^{*}$ & 0.31 & 0.14 \\
\hline $2 / 20 / 01$ & 0 & 0 & 0 & 0 & $\mathrm{n} / \mathrm{a}^{*}$ & $\mathrm{n} / \mathrm{a}^{*}$ & 0 & 0 \\
\hline $2 / 21 / 01$ & 0 & 0 & 0 & 0 & $\mathrm{n} / \mathrm{a}^{*}$ & $\mathrm{n} / \mathrm{a}^{*}$ & 0 & 0 \\
\hline $2 / 22 / 01$ & 0.08 & 0.07 & 0.10 & 0.08 & $\mathrm{n} / \mathrm{a}^{*}$ & $\mathrm{n} / \mathrm{a}^{*}$ & 0.08 & 0.08 \\
\hline $2 / 23 / 01$ & 0 & 0 & 0 & 0 & $\mathrm{n} / \mathrm{a}^{*}$ & $\mathrm{n} / \mathrm{a}^{*}$ & 0 & 0 \\
\hline $2 / 24 / 01$ & 0 & 0 & 0 & 0 & $\mathrm{n} / \mathrm{a}^{*}$ & $\mathrm{n} / \mathrm{a}^{*}$ & 0 & 0 \\
\hline $2 / 25 / 01$ & 0.02 & 0.02 & 0.05 & 0.03 & $\mathrm{n} / \mathrm{a}^{*}$ & $\mathrm{n} / \mathrm{a}^{*}$ & 0.02 & 0.03 \\
\hline $2 / 26 / 01$ & 1.53 & 1.48 & 1.35 & 1.41 & $\mathrm{n} / \mathrm{a}^{*}$ & $\mathrm{n} / \mathrm{a}^{*}$ & 0.92 & 1.34 \\
\hline $2 / 27 / 01$ & 0 & 0 & 0 & 0 & $\mathrm{n} / \mathrm{a}^{*}$ & $\mathrm{n} / \mathrm{a}^{*}$ & 0.63 & 0.13 \\
\hline $2 / 28 / 01$ & 0 & 0 & 0 & 0 & $\mathrm{n} / \mathrm{a}^{*}$ & $\mathrm{n} / \mathrm{a}^{*}$ & 0 & 0 \\
\hline $2 / 2001$ totals & 2.13 & 2.04 & 1.89 & 1.90 & $\mathrm{n} / \mathrm{a}^{*}$ & $\mathrm{n} / \mathrm{a}^{*}$ & 2.29 & 2.05 \\
\hline
\end{tabular}

* Incomplete data from the Eneu station. 
March 2001 Bikini Atoll Rain (inches)

\begin{tabular}{|c|c|c|c|c|c|c|c|c|}
\hline Date & $\begin{array}{c}\text { CP } \\
\text { South }\end{array}$ & $\begin{array}{c}\text { CP } \\
\text { North }\end{array}$ & $\begin{array}{l}\text { H36 } \\
\text { Plot }\end{array}$ & $\begin{array}{c}\text { H36 } \\
\text { Tower }\end{array}$ & $\begin{array}{l}\text { Eneu } \\
\text { West }\end{array}$ & $\begin{array}{l}\text { Eneu } \\
\text { East }\end{array}$ & $\begin{array}{l}\text { Manual } \\
\text { gage }\end{array}$ & $\begin{array}{c}\text { Bikini Isle } \\
\text { average }\end{array}$ \\
\hline $3 / 1 / 01$ & 0 & 0 & 0 & 0 & $\mathrm{n} / \mathrm{a}^{*}$ & $\mathrm{n} / \mathrm{a}^{*}$ & 0 & 0 \\
\hline $3 / 2 / 01$ & 0 & 0 & 0 & 0 & $\mathrm{n} / \mathrm{a}^{*}$ & $\mathrm{n} / \mathrm{a}^{*}$ & 0 & 0 \\
\hline $3 / 3 / 01$ & 0.06 & 0.05 & 0.06 & 0.06 & $\mathrm{n} / \mathrm{a}^{*}$ & $\mathrm{n} / \mathrm{a}^{*}$ & 0.08 & 0.06 \\
\hline $3 / 4 / 01$ & 0.01 & 0.02 & 0 & 0 & $\mathrm{n} / \mathrm{a}^{*}$ & $\mathrm{n} / \mathrm{a}^{*}$ & 0.02 & 0.01 \\
\hline $3 / 5 / 01$ & 0 & 0 & 0 & 0 & $\mathrm{n} / \mathrm{a}^{*}$ & $\mathrm{n} / \mathrm{a}^{*}$ & 0 & 0 \\
\hline $3 / 6 / 01$ & 0.06 & 0.05 & 0.06 & 0.10 & $\mathrm{n} / \mathrm{a}^{*}$ & $\mathrm{n} / \mathrm{a}^{*}$ & 0 & 0.05 \\
\hline $3 / 7 / 01$ & 0 & 0.01 & 0 & 0 & $\mathrm{n} / \mathrm{a}^{*}$ & $\mathrm{n} / \mathrm{a}^{*}$ & 0.03 & 0.01 \\
\hline $3 / 8 / 01$ & 0.06 & 0.06 & 0.05 & 0.06 & $\mathrm{n} / \mathrm{a}^{*}$ & $\mathrm{n} / \mathrm{a}^{*}$ & 0.05 & 0.06 \\
\hline $3 / 9 / 01$ & 0 & 0 & 0 & 0 & $\mathrm{n} / \mathrm{a}^{*}$ & $\mathrm{n} / \mathrm{a}^{*}$ & 0 & 0 \\
\hline $3 / 10 / 01$ & 0 & 0 & 0 & 0 & $\mathrm{n} / \mathrm{a}^{*}$ & $\mathrm{n} / \mathrm{a}^{*}$ & 0.07 & 0.01 \\
\hline $3 / 11 / 01$ & 0 & 0 & 0 & 0 & $\mathrm{n} / \mathrm{a}^{*}$ & $\mathrm{n} / \mathrm{a}^{*}$ & 0 & 0 \\
\hline $3 / 12 / 01$ & 0 & 0 & 0 & 0 & $\mathrm{n} / \mathrm{a}^{*}$ & $\mathrm{n} / \mathrm{a}^{*}$ & 0 & 0 \\
\hline $3 / 13 / 01$ & 0.04 & 0.05 & 0.03 & 0.05 & $\mathrm{n} / \mathrm{a}^{*}$ & $\mathrm{n} / \mathrm{a}^{*}$ & 0.06 & 0.05 \\
\hline $3 / 14 / 01$ & 0.31 & 0.29 & 0.29 & 0.29 & $\mathrm{n} / \mathrm{a}^{*}$ & $\mathrm{n} / \mathrm{a}^{*}$ & 0.20 & 0.28 \\
\hline $3 / 15 / 01$ & 0.04 & 0.04 & 0.05 & 0.04 & $\mathrm{n} / \mathrm{a}^{*}$ & $\mathrm{n} / \mathrm{a}^{*}$ & 0.19 & 0.07 \\
\hline $3 / 16 / 01$ & 0 & 0 & 0 & 0 & $\mathrm{n} / \mathrm{a}^{*}$ & $\mathrm{n} / \mathrm{a}^{*}$ & 0 & 0 \\
\hline $3 / 17 / 01$ & 0.01 & 0.01 & 0 & 0 & $\mathrm{n} / \mathrm{a}^{*}$ & $\mathrm{n} / \mathrm{a}^{*}$ & 0 & 0.00 \\
\hline $3 / 18 / 01$ & 0 & 0 & 0 & 0 & $\mathrm{n} / \mathrm{a}^{*}$ & $\mathrm{n} / \mathrm{a}^{*}$ & 0 & 0 \\
\hline $3 / 19 / 01$ & 0 & 0 & 0 & 0 & $\mathrm{n} / \mathrm{a}^{*}$ & $\mathrm{n} / \mathrm{a}^{*}$ & 0 & 0 \\
\hline $3 / 20 / 01$ & 0 & 0 & 0 & 0 & $\mathrm{n} / \mathrm{a}^{*}$ & $\mathrm{n} / \mathrm{a}^{*}$ & 0.02 & 0.00 \\
\hline $3 / 21 / 01$ & 0 & 0 & 0 & 0 & $\mathrm{n} / \mathrm{a}^{*}$ & $\mathrm{n} / \mathrm{a}^{*}$ & 0 & 0 \\
\hline $3 / 22 / 01$ & 0 & 0 & 0 & 0 & $\mathrm{n} / \mathrm{a}^{*}$ & $\mathrm{n} / \mathrm{a}^{*}$ & 0 & 0 \\
\hline $3 / 23 / 01$ & 0 & 0 & 0 & 0 & $\mathrm{n} / \mathrm{a}^{*}$ & $\mathrm{n} / \mathrm{a}^{*}$ & 0 & 0 \\
\hline $3 / 24 / 01$ & 0 & 0 & 0 & 0 & $\mathrm{n} / \mathrm{a}^{*}$ & $\mathrm{n} / \mathrm{a}^{*}$ & 0 & 0 \\
\hline $3 / 25 / 01$ & 0.04 & 0.04 & 0 & 0.01 & $\mathrm{n} / \mathrm{a}^{*}$ & $\mathrm{n} / \mathrm{a}^{*}$ & 0 & 0.02 \\
\hline $3 / 26 / 01$ & 0 & 0 & 0 & 0 & $\mathrm{n} / \mathrm{a}^{*}$ & $\mathrm{n} / \mathrm{a}^{*}$ & 0.05 & 0.01 \\
\hline $3 / 27 / 01$ & 0 & 0 & 0 & 0 & $\mathrm{n} / \mathrm{a}^{*}$ & $\mathrm{n} / \mathrm{a}^{*}$ & 0 & 0 \\
\hline $3 / 28 / 01$ & 0.01 & 0.01 & 0 & 0 & $\mathrm{n} / \mathrm{a}^{*}$ & $\mathrm{n} / \mathrm{a}^{*}$ & 0 & 0.00 \\
\hline $3 / 29 / 01$ & 0.07 & 0.08 & 0.06 & 0.06 & $\mathrm{n} / \mathrm{a}^{*}$ & $\mathrm{n} / \mathrm{a}^{*}$ & 0.04 & 0.06 \\
\hline $3 / 30 / 01$ & 0 & 0 & 0 & 0 & $\mathrm{n} / \mathrm{a}^{*}$ & $\mathrm{n} / \mathrm{a}^{*}$ & 0.06 & 0.01 \\
\hline $3 / 31 / 01$ & 0 & 0 & 0 & 0 & $\mathrm{n} / \mathrm{a}^{*}$ & $\mathrm{n} / \mathrm{a}^{*}$ & 0 & 0 \\
\hline $3 / 2001$ totals & 0.71 & 0.71 & 0.60 & 0.67 & $\mathrm{n} / \mathrm{a}^{*}$ & $\mathrm{n} / \mathrm{a}^{*}$ & 0.87 & 0.71 \\
\hline
\end{tabular}

* Incomplete data from the Eneu station. 
April 2001 Bikini Atoll Rain (inches)

\begin{tabular}{|c|c|c|c|c|c|c|c|c|}
\hline Date & $\begin{array}{c}\text { CP } \\
\text { South }\end{array}$ & $\begin{array}{c}\text { CP } \\
\text { North }\end{array}$ & $\begin{array}{l}\text { H36 } \\
\text { Plot }\end{array}$ & $\begin{array}{c}\text { H36 } \\
\text { Tower }\end{array}$ & $\begin{array}{l}\text { Eneu } \\
\text { West }\end{array}$ & $\begin{array}{l}\text { Eneu } \\
\text { East }\end{array}$ & $\begin{array}{c}\text { Manual } \\
\text { gage }\end{array}$ & $\begin{array}{c}\text { Bikini Isle } \\
\text { average }\end{array}$ \\
\hline $4 / 1 / 01$ & 0.02 & 0.02 & 0.03 & 0.01 & $\mathrm{n} / \mathrm{a}^{*}$ & $\mathrm{n} / \mathrm{a}^{*}$ & 0.04 & 0.02 \\
\hline $4 / 2 / 01$ & 0.31 & 0.30 & 0.39 & 0.37 & $\mathrm{n} / \mathrm{a}^{*}$ & $\mathrm{n} / \mathrm{a}^{*}$ & 0.33 & 0.34 \\
\hline $4 / 3 / 01$ & 0.03 & 0.03 & 0 & 0 & $\mathrm{n} / \mathrm{a}^{*}$ & $\mathrm{n} / \mathrm{a}^{*}$ & $\mathrm{n} / \mathrm{a}^{*}$ & 0.02 \\
\hline $4 / 4 / 01$ & 0.07 & 0.07 & 0.04 & 0.04 & $\mathrm{n} / \mathrm{a}^{*}$ & $\mathrm{n} / \mathrm{a}^{*}$ & 0.13 & 0.07 \\
\hline $4 / 5 / 01$ & 0 & 0 & 0 & 0 & 0 & 0 & 0 & 0 \\
\hline $4 / 6 / 01$ & 0.04 & 0.05 & 0.05 & 0.02 & 0 & 0 & 0.04 & 0.04 \\
\hline $4 / 7 / 01$ & 0 & 0 & 0.01 & 0.01 & 0 & 0.01 & 0 & 0.00 \\
\hline $4 / 8 / 01$ & 0.03 & 0.04 & 0.01 & 0.01 & 0 & 0 & 0.03 & 0.02 \\
\hline $4 / 9 / 01$ & 0 & 0 & 0 & 0 & 0 & 0 & 0 & 0 \\
\hline $4 / 10 / 01$ & 0 & 0 & 0 & 0 & 0.01 & 0 & 0 & 0 \\
\hline $4 / 11 / 01$ & 0 & 0 & 0 & 0 & 0 & 0 & 0 & 0 \\
\hline $4 / 12 / 01$ & 0.05 & 0.04 & 0.09 & 0.05 & 0.05 & 0.06 & 0 & 0.05 \\
\hline $4 / 13 / 01$ & 0.01 & 0.02 & 0 & 0.01 & 0.01 & 0 & 0 & 0.01 \\
\hline $4 / 14 / 01$ & 0.02 & 0.02 & 0.05 & 0.04 & 0 & 0 & 0.07 & 0.04 \\
\hline $4 / 15 / 01$ & 0.01 & 0.01 & 0.08 & 0.08 & 0.01 & 0.01 & 0.02 & 0.04 \\
\hline $4 / 16 / 01$ & 0.08 & 0.08 & 0.05 & 0.06 & 0 & 0 & 0 & 0.05 \\
\hline $4 / 17 / 01$ & 0 & 0 & 0 & 0 & 0 & 0 & 0.13 & 0.03 \\
\hline $4 / 18 / 01$ & 0 & 0 & 0 & 0 & 0 & 0 & 0 & 0 \\
\hline $4 / 19 / 01$ & 0 & 0 & 0 & 0 & 0 & 0 & 0 & 0 \\
\hline $4 / 20 / 01$ & 0 & 0 & 0 & 0 & 0 & 0 & 0.01 & 0.00 \\
\hline $4 / 21 / 01$ & 0 & 0 & 0 & 0 & 0.01 & 0 & 0 & 0 \\
\hline $4 / 22 / 01$ & 0 & 0 & 0 & 0 & 0 & 0 & 0 & 0 \\
\hline $4 / 23 / 01$ & 0 & 0 & 0 & 0 & 0 & 0 & 0 & 0 \\
\hline $4 / 24 / 01$ & 0 & 0 & 0 & 0 & 0 & 0 & 0 & 0 \\
\hline $4 / 25 / 01$ & 0 & 0 & 0 & 0 & 0 & 0 & 0 & 0 \\
\hline $4 / 26 / 01$ & 0.29 & 0.30 & 0.27 & 0.26 & 0.08 & 0.09 & 0.32 & 0.29 \\
\hline $4 / 27 / 01$ & 0.01 & 0 & 0 & 0 & 0 & 0.01 & 0.01 & 0.00 \\
\hline $4 / 28 / 01$ & 0 & 0 & 0 & 0 & 0 & 0 & 0 & 0 \\
\hline $4 / 29 / 01$ & 0 & 0 & 0 & 0 & 0 & 0 & 0 & 0 \\
\hline $4 / 30 / 01$ & 0.01 & 0.01 & 0.01 & 0 & 0 & 0 & 0.03 & 0.01 \\
\hline $4 / 2001$ totals & 0.98 & 0.99 & 1.08 & 0.96 & 0.17 & 0.18 & 1.16 & 1.03 \\
\hline
\end{tabular}

* Incomplete data from the Eneu station. 
Appendix F

Historical Monthly Totals of Rainfall 
Bikini Atoll historical monthly rain (inches).

\begin{tabular}{|c|c|c|c|c|c|c|c|c|}
\hline Date & $\begin{array}{c}\text { CP } \\
\text { South }\end{array}$ & $\begin{array}{c}\text { CP } \\
\text { North }\end{array}$ & $\begin{array}{l}\text { H36 } \\
\text { Plot }\end{array}$ & $\begin{array}{c}\text { H36 } \\
\text { Tower }\end{array}$ & $\begin{array}{l}\text { Eneu } \\
\text { West }\end{array}$ & $\begin{array}{l}\text { Eneu } \\
\text { East }\end{array}$ & $\begin{array}{c}\text { Manual } \\
\text { gage }\end{array}$ & $\begin{array}{c}\text { Bikini Isle } \\
\text { average }\end{array}$ \\
\hline 7/1985 & 4.14 & * & & * & * & * & 4.08 & 4.11 \\
\hline $8 / 1985$ & 7.72 & * & * & * & * & * & 7.83 & 7.78 \\
\hline 9/1985 & 7.86 & * & * & * & * & * & 7.73 & 7.80 \\
\hline $10 / 1985$ & 6.68 & * & * & * & * & * & 6.58 & 6.63 \\
\hline $11 / 1985$ & 4.18 & * & * & * & * & * & 4.29 & 4.24 \\
\hline $12 / 1985$ & 3.08 & * & * & * & * & * & 2.99 & 3.04 \\
\hline 1/1986 & 3.72 & * & * & * & * & * & 3.73 & 3.73 \\
\hline $2 / 1986$ & 0.19 & * & * & * & * & * & 0.20 & 0.20 \\
\hline $3 / 1986$ & 1.13 & * & * & * & * & * & 1.14 & 1.14 \\
\hline 4/1986 & 1.83 & * & * & * & * & * & 1.88 & 1.86 \\
\hline $5 / 1986$ & 4.52 & * & * & * & * & * & 7.85 & 6.19 \\
\hline $6 / 1986$ & 3.75 & * & * & * & * & * & 5.80 & 4.78 \\
\hline 7/1986 & * & * & * & * & * & * & 6.92 & 6.92 \\
\hline $8 / 1986$ & * & * & * & * & * & * & 16.57 & 16.57 \\
\hline $9 / 1986$ & * & * & * & * & * & * & 16.39 & 16.39 \\
\hline $10 / 1986$ & * & * & * & * & * & * & 9.76 & 9.76 \\
\hline $11 / 1986$ & * & * & * & * & * & * & 6.90 & 6.90 \\
\hline $12 / 1986$ & * & * & * & * & * & * & 4.91 & 4.91 \\
\hline $1 / 1987$ & * & * & * & * & * & * & 0.68 & 0.68 \\
\hline $2 / 1987$ & * & * & * & * & * & * & 0.73 & 0.73 \\
\hline $3 / 1987$ & * & * & * & * & * & * & 0.69 & 0.69 \\
\hline $4 / 1987$ & * & * & * & * & * & * & 3.18 & 3.18 \\
\hline $5 / 1987$ & * & * & * & * & * & * & 0.60 & 0.60 \\
\hline $6 / 1987$ & * & * & * & * & * & * & 1.55 & 1.55 \\
\hline 7/1987 & * & * & * & * & * & * & 4.44 & 4.44 \\
\hline $8 / 1987$ & * & * & * & * & * & * & 7.23 & 7.23 \\
\hline 9/1987 & * & * & * & * & * & * & 6.53 & 6.53 \\
\hline $10 / 1987$ & * & * & * & * & * & * & 7.55 & 7.55 \\
\hline 11/1987 & * & * & * & * & * & * & 8.63 & 8.63 \\
\hline $12 / 1987$ & * & * & * & * & * & * & 3.17 & 3.17 \\
\hline $1 / 1988$ & * & * & * & * & * & * & 1.95 & 1.95 \\
\hline 2/1988 & * & * & * & * & * & * & 0.80 & 0.80 \\
\hline $3 / 1988$ & * & * & * & * & * & * & 1.39 & 1.39 \\
\hline $4 / 1988$ & * & * & * & * & * & * & 0.98 & 0.98 \\
\hline $5 / 1988$ & * & * & * & * & * & * & 1.22 & 1.22 \\
\hline $6 / 1988$ & * & * & * & * & * & * & 8.67 & 8.67 \\
\hline 7/1988 & * & * & * & * & * & * & 7.47 & 7.47 \\
\hline 8/1988 & * & * & * & * & * & * & 5.27 & 5.27 \\
\hline 9/1988 & * & * & * & * & * & * & 9.52 & 9.52 \\
\hline $10 / 1988$ & * & * & * & * & * & * & 7.17 & 7.17 \\
\hline $11 / 1988$ & * & * & * & * & * & * & 4.66 & 4.66 \\
\hline $12 / 1988$ & * & * & * & * & * & * & 1.74 & 1.74 \\
\hline $1 / 1989$ & * & * & * & * & * & * & 1.69 & 1.69 \\
\hline 2/1989 & * & * & * & * & * & * & 2.17 & 2.17 \\
\hline $3 / 1989$ & * & * & * & * & * & * & 2.07 & 2.07 \\
\hline 4/1989 & * & * & * & * & * & * & 2.69 & 2.69 \\
\hline $5 / 1989$ & * & * & * & * & * & * & 5.40 & 5.40 \\
\hline $6 / 1989$ & * & * & * & * & * & * & 12.02 & 12.02 \\
\hline 7/1989 & * & * & * & * & * & * & 14.04 & 14.04 \\
\hline 8/1989 & * & * & * & * & * & * & 10.22 & 10.22 \\
\hline 9/1989 & * & * & * & * & * & * & 10.29 & 10.29 \\
\hline $10 / 1989$ & * & * & * & * & * & * & 4.11 & 4.11 \\
\hline
\end{tabular}


Bikini Atoll historical monthly rain (inches) (continued).

\begin{tabular}{|c|c|c|c|c|c|c|c|c|}
\hline Date & $\begin{array}{c}\text { CP } \\
\text { South }\end{array}$ & $\begin{array}{c}\text { CP } \\
\text { North }\end{array}$ & $\begin{array}{l}\text { H36 } \\
\text { Plot }\end{array}$ & $\begin{array}{c}\text { H36 } \\
\text { Tower }\end{array}$ & $\begin{array}{l}\text { Eneu } \\
\text { West }\end{array}$ & $\begin{array}{l}\text { Eneu } \\
\text { East }\end{array}$ & $\begin{array}{c}\text { Manual } \\
\text { gage }\end{array}$ & $\begin{array}{c}\text { Bikini Isle } \\
\text { average }\end{array}$ \\
\hline 11/1989 & * & * & * & * & * & * & 5.49 & 5.49 \\
\hline $12 / 1989$ & * & * & * & * & * & * & 1.68 & 1.68 \\
\hline 1/1990 & * & * & * & * & 2.40 & * & 3.79 & 3.79 \\
\hline $2 / 1990$ & * & * & * & * & 2.07 & * & 3.23 & 3.23 \\
\hline $3 / 1990$ & * & * & * & * & 12.12 & * & 9.49 & 9.49 \\
\hline 4/1990 & 1.42 & 1.27 & 1.40 & 1.36 & 1.66 & * & 1.62 & 1.44 \\
\hline $5 / 1990$ & 3.09 & 2.80 & 2.88 & 3.21 & 3.11 & * & 3.43 & 3.11 \\
\hline $6 / 1990$ & 7.52 & 6.98 & 7.42 & 8.04 & 3.95 & * & 8.23 & 7.58 \\
\hline 7/1990 & 13.12 & 11.77 & 11.04 & 11.69 & 15.33 & * & 13.54 & 12.81 \\
\hline $8 / 1990$ & * & * & 5.64 & 6.00 & 6.80 & * & 6.93 & 6.93 \\
\hline 9/1990 & 15.31 & 14.49 & 14.65 & 14.89 & 10.45 & * & 16.02 & 15.27 \\
\hline $10 / 1990$ & * & * & 7.54 & 8.22 & 10.28 & * & 8.94 & 8.94 \\
\hline $11 / 1990$ & * & * & 18.70 & 20.26 & 15.20 & * & 20.88 & 20.88 \\
\hline $12 / 1990$ & * & 7.16 & 7.55 & 8.22 & 5.03 & * & 8.15 & 7.66 \\
\hline 1/1991 & * & 0.77 & 0.72 & 0.87 & 0.82 & * & 1.46 & 1.12 \\
\hline 2/1991 & 2.04 & 2.06 & 2.12 & 2.40 & 1.74 & * & 2.34 & 2.15 \\
\hline 3/1991 & 3.43 & 3.45 & $*$ & 3.78 & 2.64 & * & 4.39 & 3.76 \\
\hline 4/1991 & 5.18 & 5.27 & * & 5.89 & 5.31 & * & 6.19 & 5.55 \\
\hline 5/1991 & 2.31 & 2.29 & * & 2.32 & 2.61 & * & 2.75 & 2.45 \\
\hline 6/1991 & * & * & * & 2.23 & 2.62 & * & 2.09 & 2.09 \\
\hline 7/1991 & * & * & * & 3.77 & 3.57 & * & 4.40 & 4.40 \\
\hline 8/1991 & 10.86 & 10.30 & * & 11.26 & 8.09 & * & 12.50 & 11.22 \\
\hline 9/1991 & 6.98 & 7.18 & * & 7.47 & 9.13 & * & 7.88 & 7.35 \\
\hline 10/1991 & 16.60 & 16.47 & * & 18.37 & 8.51 & * & 18.95 & 17.34 \\
\hline 11/1991 & 8.48 & 8.76 & * & 10.26 & 9.52 & * & 8.36 & 8.53 \\
\hline 12/1991 & 2.09 & 2.25 & * & 2.56 & 1.56 & * & 2.67 & 2.34 \\
\hline 1/1992 & 1.08 & 1.25 & * & 1.48 & 1.80 & * & 1.94 & 1.42 \\
\hline 2/1992 & 0.68 & 0.81 & * & 0.88 & 0.80 & * & 1.33 & 0.94 \\
\hline 3/1992 & 1.66 & 1.94 & * & 2.21 & 2.17 & * & 2.37 & 1.99 \\
\hline 4/1992 & 0.52 & 0.49 & * & 0.63 & 1.57 & * & * & 0.51 \\
\hline 5/1992 & 0.35 & 0.39 & 0.25 & 0.39 & 0.92 & * & * & 0.37 \\
\hline 6/1992 & 2.34 & 2.23 & 2.28 & 2.67 & 1.33 & * & 3.64 & 2.74 \\
\hline 7/1992 & 2.52 & 2.38 & 2.64 & 2.88 & 1.96 & * & 3.29 & 2.73 \\
\hline 8/1992 & 8.28 & 8.04 & 7.99 & 8.55 & 11.29 & * & 8.92 & 8.41 \\
\hline 9/1992 & 7.53 & 7.15 & 8.31 & 8.08 & 6.42 & * & 7.06 & 7.25 \\
\hline $10 / 1992$ & 11.57 & 10.52 & 12.75 & 12.90 & 8.40 & * & 13.38 & 11.82 \\
\hline $11 / 1992$ & 15.84 & * & * & * & 12.73 & * & 14.60 & 15.22 \\
\hline 12/1992 & 2.40 & 2.11 & 2.59 & 2.64 & 4.25 & * & 2.84 & 2.45 \\
\hline 1/1993 & 0.98 & 0.89 & 0.84 & 0.91 & 3.84 & * & 1.08 & 0.98 \\
\hline 2/1993 & 0.46 & 0.37 & 0.40 & 0.45 & 0.40 & * & 0.61 & 0.48 \\
\hline $3 / 1993$ & 0.41 & 0.39 & 0.33 & 0.39 & & * & 0.75 & 0.52 \\
\hline 4/1993 & 0.50 & 0.48 & * & * & 1.03 & * & 0.59 & 0.52 \\
\hline $5 / 1993$ & 0.85 & 0.83 & * & * & 1.04 & * & 0.61 & 0.76 \\
\hline 6/1993 & 1.79 & 1.14 & * & * & 0.86 & * & 1.64 & 1.52 \\
\hline 7/1993 & 7.13 & * & * & * & 4.56 & * & 7.37 & 7.25 \\
\hline 8/1993 & 7.39 & * & 6.95 & 6.86 & 5.66 & * & 7.40 & 7.40 \\
\hline 9/1993 & 9.32 & 8.89 & 10.15 & 10.57 & 7.78 & * & 8.54 & 8.92 \\
\hline $10 / 1993$ & 10.56 & 9.88 & 9.96 & 9.79 & 11.37 & * & 10.42 & 10.29 \\
\hline $11 / 1993$ & * & * & * & * & $*$ & * & 14.26 & 14.26 \\
\hline $12 / 1993$ & * & * & * & * & * & * & 7.84 & 7.84 \\
\hline 1/1994 & 0.66 & 0.64 & 0.69 & 0.69 & * & * & 0.89 & 0.73 \\
\hline 2/1994 & 0.22 & 0.23 & 0.17 & 0.18 & * & * & 0.40 & 0.28 \\
\hline
\end{tabular}


Bikini Atoll historical monthly rain (inches) (continued).

\begin{tabular}{|c|c|c|c|c|c|c|c|c|}
\hline Date & $\begin{array}{c}\text { CP } \\
\text { South }\end{array}$ & $\begin{array}{c}\text { CP } \\
\text { North }\end{array}$ & $\begin{array}{l}\text { H36 } \\
\text { Plot }\end{array}$ & $\begin{array}{c}\text { H36 } \\
\text { Tower }\end{array}$ & $\begin{array}{l}\text { Eneu } \\
\text { West }\end{array}$ & $\begin{array}{l}\text { Eneu } \\
\text { East }\end{array}$ & $\begin{array}{c}\text { Manual } \\
\text { gage }\end{array}$ & $\begin{array}{c}\text { Bikini Isle } \\
\text { average }\end{array}$ \\
\hline 3/1994 & 0.64 & 0.61 & 0.71 & 0.68 & * & * & 0.89 & 0.71 \\
\hline 4/1994 & 2.14 & 2.03 & 2.04 & 2.19 & * & * & 2.30 & 2.16 \\
\hline 5/1994 & 2.32 & 2.13 & 2.34 & 2.51 & * & * & 2.47 & 2.31 \\
\hline 6/1994 & * & * & 9.38 & 10.72 & 7.31 & * & 9.99 & 9.99 \\
\hline 7/1994 & * & * & 8.77 & 10.51 & 7.36 & * & 11.34 & 11.34 \\
\hline 8/1994 & * & * & * & * & $*$ & * & 4.63 & 4.63 \\
\hline $9 / 1994$ & * & * & * & * & * & * & 14.05 & 14.05 \\
\hline $10 / 1994$ & * & * & 8.02 & 8.83 & 2.03 & * & 10.49 & 10.49 \\
\hline 11/1994 & * & * & 5.23 & 5.27 & & * & 6.62 & 6.62 \\
\hline $12 / 1994$ & 4.03 & 2.98 & 3.56 & 3.98 & 6.73 & * & 4.35 & 3.79 \\
\hline 1/1995 & 1.18 & 1.12 & 1.22 & 1.22 & 0.54 & * & 1.79 & 1.36 \\
\hline 2/1995 & 0.11 & 0.11 & 0.18 & 0.15 & 0.05 & * & 0.20 & 0.14 \\
\hline 3/1995 & 1.17 & 1.07 & 1.00 & 1.08 & 1.13 & * & 1.57 & 1.27 \\
\hline 4/1995 & 4.08 & 3.84 & 3.90 & 4.19 & 2.66 & * & 4.58 & 4.17 \\
\hline 5/1995 & 8.25 & $*$ & 7.95 & 8.24 & $*$ & * & 8.20 & 8.23 \\
\hline 6/1995 & 1.59 & 1.36 & 1.60 & 1.62 & 2.59 & * & 2.02 & 1.66 \\
\hline 7/1995 & 6.05 & 5.42 & 5.83 & 5.77 & 5.85 & * & 6.92 & 6.13 \\
\hline 8/1995 & 8.97 & 8.32 & 9.04 & 8.88 & * & * & 9.29 & 8.86 \\
\hline 9/1995 & 5.72 & 5.35 & 5.44 & 5.62 & * & * & 6.43 & 5.83 \\
\hline $10 / 1995$ & 9.70 & 8.72 & 9.66 & 10.05 & * & * & 9.80 & 9.41 \\
\hline $11 / 1995$ & 4.72 & 4.44 & 4.65 & 4.62 & * & * & 5.44 & 4.87 \\
\hline $12 / 1995$ & 0.90 & 0.93 & 0.90 & 0.88 & * & * & 1.54 & 1.12 \\
\hline 1/1996 & 3.12 & 2.93 & 3.20 & 3.39 & * & * & 3.60 & 3.22 \\
\hline 2/1996 & 3.02 & 2.84 & 2.74 & 3.06 & * & * & 3.11 & 2.99 \\
\hline 3/1996 & 4.25 & 3.41 & 4.27 & 4.53 & * & * & 5.30 & 4.32 \\
\hline 4/1996 & 1.62 & 1.15 & 1.54 & 1.59 & * & * & 2.09 & 1.62 \\
\hline 5/1996 & 0.64 & 0.61 & 0.63 & 0.63 & * & * & 0.82 & 0.69 \\
\hline $6 / 1996$ & * & * & * & * & * & * & 7.36 & 7.36 \\
\hline 7/1996 & 6.03 & 5.54 & 5.42 & 6.25 & * & * & 7.13 & 6.23 \\
\hline 8/1996 & 5.76 & 4.63 & 5.09 & 5.77 & * & * & 7.19 & 5.86 \\
\hline 9/1996 & 10.37 & 7.77 & 9.44 & 10.57 & * & * & 11.40 & 9.85 \\
\hline $10 / 1996$ & 6.98 & 5.62 & 6.10 & 6.54 & * & * & 8.03 & 6.88 \\
\hline $11 / 1996$ & * & * & $*$ & * & * & * & 12.02 & 12.02 \\
\hline $12 / 1996$ & * & * & * & * & * & * & *5.47 & 5.47 \\
\hline 1/1997 & 1.82 & 1.08 & 1.91 & 1.91 & * & * & 2.06 & 2.06 \\
\hline 2/1997 & 1.51 & 1.42 & 2.21 & 2.27 & * & * & 2.44 & 2.44 \\
\hline 3/1997 & 11.46 & 7.84 & 11.43 & 12.15 & * & * & 12.60 & 12.60 \\
\hline 4/1997 & 6.23 & 5.66 & 6.48 & 6.82 & * & * & 6.85 & 6.85 \\
\hline 5/1997 & 9.58 & 8.50 & 4.96 & 8.95 & * & * & 10.61 & 10.61 \\
\hline 6/1997 & 4.14 & 3.56 & 2.83 & 4.06 & * & * & 3.35 & 3.35 \\
\hline 7/1997 & 3.16 & 2.65 & 2.27 & 3.10 & * & * & 3.99 & 3.99 \\
\hline 8/1997 & 18.13 & 15.55 & 15.21 & 18.48 & * & * & 19.16 & 19.16 \\
\hline 9/1997 & 17.26 & 15.15 & 15.01 & 18.74 & * & * & 18.95 & 18.95 \\
\hline 10/1997 & 7.62 & 6.60 & 5.57 & 8.20 & * & * & 7.78 & 7.78 \\
\hline 11/1997 & 2.50 & 2.08 & 1.99 & 2.55 & * & * & 2.87 & 2.87 \\
\hline $12 / 1997$ & 3.88 & 3.23 & 3.20 & 3.79 & * & * & 4.61 & 4.61 \\
\hline 1/1998 & 1.37 & 1.23 & 0.91 & 1.35 & * & * & 1.96 & 1.96 \\
\hline 2/1998 & 0.74 & 0.63 & 0.40 & 0.70 & * & * & 1.24 & 1.24 \\
\hline 3/1998 & 0.98 & 0.84 & 0.55 & 0.90 & * & * & 1.42 & 1.42 \\
\hline 4/1998 & 1.69 & 1.40 & 1.44 & 1.74 & * & * & 2.16 & 2.16 \\
\hline $5 / 1998$ & 0.70 & 0.58 & 0.46 & 0.55 & * & * & 0.64 & 0.64 \\
\hline $6 / 1998$ & 3.73 & 2.27 & 2.65 & 3.40 & * & * & 3.93 & 3.93 \\
\hline 7/1998 & 3.84 & 3.18 & 3.58 & 3.92 & * & * & 4.58 & 4.58 \\
\hline
\end{tabular}


Bikini Atoll historical monthly rain (inches) (continued).

\begin{tabular}{|c|c|c|c|c|c|c|c|c|}
\hline Date & $\begin{array}{c}\text { CP } \\
\text { South }\end{array}$ & $\begin{array}{c}\text { CP } \\
\text { North }\end{array}$ & $\begin{array}{l}\text { H36 } \\
\text { Plot }\end{array}$ & $\begin{array}{c}\text { H36 } \\
\text { Tower }\end{array}$ & $\begin{array}{l}\text { Eneu } \\
\text { West }\end{array}$ & $\begin{array}{l}\text { Eneu } \\
\text { East }\end{array}$ & $\begin{array}{c}\text { Manual } \\
\text { gage }\end{array}$ & $\begin{array}{c}\text { Bikini Isle } \\
\text { average }\end{array}$ \\
\hline 8/1998 & 3.09 & 2.09 & 2.71 & 2.90 & * & * & 3.61 & 3.61 \\
\hline 9/1998 & 5.44 & 4.13 & 4.86 & 5.40 & * & * & 6.54 & 6.54 \\
\hline $10 / 1998$ & 6.45 & 3.65 & * & & * & * & 8.26 & 8.26 \\
\hline $11 / 1998$ & 5.79 & 4.19 & * & 1.78 & * & * & 6.59 & 6.59 \\
\hline $12 / 1998$ & 1.53 & 1.14 & * & 1.55 & * & * & 2.55 & 2.55 \\
\hline 1/1999 & 1.66 & 0.81 & * & 1.65 & * & * & 2.27 & 2.27 \\
\hline 2/1999 & 0.47 & 0.20 & * & 0.35 & * & * & 0.83 & 0.83 \\
\hline $3 / 1999$ & 0.60 & 0.39 & * & 0.54 & * & * & 1.51 & 1.51 \\
\hline 4/1999 & 1.02 & 0.65 & * & 0.88 & * & * & 1.37 & 1.37 \\
\hline 5/1999 & 2.82 & 1.96 & * & * & * & * & 1.49 & 1.49 \\
\hline 6/1999 & 1.02 & 2.04 & * & * & * & * & 3.57 & 3.57 \\
\hline 7/1999 & 4.19 & 1.21 & * & * & * & * & 5.22 & 5.22 \\
\hline 8/1999 & 2.14 & * & * & * & * & * & 2.88 & 2.88 \\
\hline 9/1999 & 6.33 & * & * & * & * & * & 7.14 & 7.14 \\
\hline $10 / 1999$ & 4.77 & 3.30 & 2.03 & 2.62 & * & * & 4.72 & 4.72 \\
\hline 11/1999 & 6.77 & 6.90 & 5.23 & 6.66 & * & * & 7.22 & 7.22 \\
\hline 12/1999 & 0.43 & 0.43 & 0.29 & 0.48 & * & * & 0.99 & 0.99 \\
\hline $1 / 2000$ & $*$ & $*$ & * & $*$ & * & * & 0.88 & 0.88 \\
\hline $2 / 2000$ & * & * & * & * & * & * & 2.56 & 2.56 \\
\hline $3 / 2000$ & * & * & * & * & * & * & 1.13 & 1.13 \\
\hline $4 / 2000$ & * & * & * & * & * & * & 0.93 & 0.93 \\
\hline $5 / 2000$ & 0.98 & 0.96 & 0.87 & 0.90 & 1.13 & 1.19 & 0.96 & 0.92 \\
\hline $6 / 2000$ & 1.50 & 1.43 & 1.84 & 1.51 & 1.01 & 1.08 & 1.61 & 1.27 \\
\hline $7 / 2000$ & 9.56 & 9.21 & 8.81 & 8.68 & 6.16 & 6.30 & 10.14 & 9.59 \\
\hline $8 / 2000$ & 7.31 & 7.14 & * & * & 9.10 & 9.45 & 7.61 & 7.38 \\
\hline $9 / 2000$ & 2.94 & 2.81 & 2.76 & 2.49 & 3.02 & 3.08 & 3.24 & 3.05 \\
\hline $10 / 2000$ & 5.46 & 5.31 & 5.37 & 5.00 & 5.41 & 5.64 & 5.58 & 5.22 \\
\hline $11 / 2000$ & 13.46 & 13.23 & 13.42 & 12.75 & 8 & * & 14.31 & 13.34 \\
\hline $12 / 2000$ & 2.46 & 2.38 & 2.25 & 2.32 & * & * & 2.97 & 2.57 \\
\hline $1 / 2001$ & 1.11 & 1.08 & 0.84 & 0.95 & * & * & 1.10 & 1.02 \\
\hline $2 / 2001$ & 2.13 & 2.04 & 1.89 & 1.90 & * & * & 2.29 & 2.05 \\
\hline $3 / 2001$ & 0.73 & 0.73 & 0.62 & 0.68 & * & * & 0.87 & 0.71 \\
\hline $4 / 2001$ & 0.98 & 0.98 & 1.07 & 0.97 & * & * & 1.16 & 1.03 \\
\hline
\end{tabular}

* Incomplete data. 


\section{Appendix G}

Wind Rose Tables 
These wind rose tables are made from Bikini Atoll data takes from 9 May 2000 through 30 April 2001. All available data was included in the statistics. Wind speed classes are based on the integer portion of the wind speed. For example, the wind speed class 0 includes wind speeds from 0 to $0.999 \mathrm{~m} / \mathrm{s}$; class 1 includes speeds from 1.0 to 1.999 $\mathrm{m} / \mathrm{s}$. The wind direction classes are centered on the indicated direction.

The wind rose diagrams are created from the data in the tables. The roses group the wind speed classes into 5 groups: Calms, 1 to $2.999 \mathrm{~m} / \mathrm{s}, 3$ to $3.999,4$ to 4.999 , and 5.0 and greater. The calms are distributed evenly among all 16 wind direction classes.

\begin{tabular}{|c|c|c|c|c|c|c|c|c|c|c|}
\hline \multicolumn{4}{|c|}{ Control Plot $\mathrm{N}=8439$} & \multicolumn{4}{|c|}{ Wind Speed Class } & \multirow[b]{2}{*}{6} & \multirow[b]{2}{*}{7} & \multirow[b]{2}{*}{8} \\
\hline Wind from & Total & 0 & 1 & 2 & 3 & 4 & 5 & & & \\
\hline$S$ & $0 \%$ & 32 & 40 & 1 & 0 & 0 & 0 & 0 & 0 & 0 \\
\hline SSE & $0 \%$ & 48 & 14 & 4 & 0 & 0 & 0 & 0 & 0 & 0 \\
\hline SE & $1 \%$ & 86 & 79 & 38 & 2 & 1 & 0 & 0 & 0 & 0 \\
\hline ESE & $6 \%$ & 83 & 256 & 173 & 36 & 4 & 1 & 0 & 0 & 0 \\
\hline $\mathrm{E}$ & $25 \%$ & 64 & 407 & 1120 & 527 & 48 & 1 & 0 & 0 & 0 \\
\hline ENE & $47 \%$ & 65 & 404 & 1871 & 1478 & 201 & 4 & 0 & 0 & 0 \\
\hline $\mathrm{NE}$ & $9 \%$ & 57 & 160 & 414 & 174 & 16 & 0 & 0 & 0 & 0 \\
\hline NNE & $1 \%$ & 59 & 71 & 11 & 0 & 0 & 0 & 0 & 0 & 0 \\
\hline $\mathrm{N}$ & $0 \%$ & 108 & 19 & 3 & 0 & 0 & 0 & 0 & 0 & 0 \\
\hline NNW & $0 \%$ & 20 & 1 & 0 & 0 & 0 & 0 & 0 & 0 & 0 \\
\hline NW & $0 \%$ & 41 & 2 & 0 & 0 & 0 & 0 & 0 & 0 & 0 \\
\hline WNW & $0 \%$ & 19 & 7 & 2 & 0 & 0 & 0 & 0 & 0 & 0 \\
\hline $\mathrm{W}$ & $0 \%$ & 13 & 12 & 0 & 0 & 0 & 0 & 0 & 0 & 0 \\
\hline WSW & $0 \%$ & 9 & 13 & 0 & 0 & 0 & 0 & 0 & 0 & 0 \\
\hline SW & $0 \%$ & 7 & 24 & 1 & 0 & 0 & 0 & 0 & 0 & 0 \\
\hline SSW & $1 \%$ & 30 & 58 & 0 & 0 & 0 & 0 & 0 & 0 & 0 \\
\hline & Total & $9 \%$ & $19 \%$ & $43 \%$ & $26 \%$ & $3 \%$ & $0 \%$ & $0 \%$ & $0 \%$ & $0 \%$ \\
\hline $\mathrm{Cu}$ & ative & $9 \%$ & $27 \%$ & $70 \%$ & $97 \%$ & $100 \%$ & $100 \%$ & $100 \%$ & $100 \%$ & $100 \%$ \\
\hline
\end{tabular}




\begin{tabular}{|c|c|c|c|c|c|c|c|c|c|c|}
\hline \multicolumn{3}{|l|}{ Eneu N=3567 } & \multicolumn{4}{|c|}{ Wind Speed Class } & \multirow[b]{2}{*}{5} & \multirow[b]{2}{*}{6} & \multirow[b]{2}{*}{7} & \multirow[b]{2}{*}{8} \\
\hline Wind from & Total & 0 & 1 & 2 & 3 & 4 & & & & \\
\hline$S$ & $0 \%$ & 5 & 8 & 5 & 0 & 1 & 0 & 0 & 0 & 0 \\
\hline SSE & $1 \%$ & 5 & 16 & 5 & 1 & 0 & 0 & 0 & 0 & 0 \\
\hline SE & $1 \%$ & 5 & 23 & 20 & 5 & 3 & 0 & 0 & 0 & 0 \\
\hline ESE & $2 \%$ & 5 & 16 & 23 & 14 & 8 & 1 & 0 & 1 & 0 \\
\hline $\mathrm{E}$ & $5 \%$ & 8 & 28 & 77 & 62 & 15 & 2 & 0 & 0 & 0 \\
\hline ENE & $31 \%$ & 9 & 40 & 305 & 593 & 149 & 6 & 1 & 0 & 0 \\
\hline $\mathrm{NE}$ & $41 \%$ & 11 & 96 & 309 & 681 & 312 & 52 & 12 & 0 & 0 \\
\hline NNE & $11 \%$ & 22 & 81 & 138 & 90 & 55 & 18 & 23 & 0 & 0 \\
\hline $\mathrm{N}$ & $2 \%$ & 42 & 25 & 27 & 20 & 2 & 7 & 0 & 0 & 0 \\
\hline NNW & $1 \%$ & 2 & 10 & 5 & 5 & 0 & 0 & 0 & 0 & 0 \\
\hline NW & $0 \%$ & 2 & 3 & 0 & 2 & 0 & 0 & 0 & 0 & 0 \\
\hline WNW & $0 \%$ & 3 & 4 & 0 & 0 & 0 & 0 & 0 & 0 & 0 \\
\hline $\mathrm{W}$ & $0 \%$ & 2 & 12 & 1 & 2 & 0 & 0 & 0 & 0 & 0 \\
\hline WSW & $0 \%$ & 0 & 1 & 0 & 0 & 0 & 0 & 0 & 0 & 0 \\
\hline SW & $0 \%$ & 9 & 2 & 5 & 0 & 0 & 0 & 0 & 0 & 0 \\
\hline \multirow[t]{3}{*}{ SSW } & $0 \%$ & 4 & 3 & 1 & 1 & 0 & 0 & 0 & 0 & 0 \\
\hline & Total & $4 \%$ & $10 \%$ & $26 \%$ & $41 \%$ & $15 \%$ & $2 \%$ & $1 \%$ & $0 \%$ & $0 \%$ \\
\hline & ulative & $4 \%$ & $14 \%$ & $40 \%$ & $81 \%$ & $97 \%$ & $99 \%$ & $100 \%$ & $100 \%$ & $100 \%$ \\
\hline \multicolumn{3}{|c|}{ House $36 \mathrm{~N}=6638$} & \multicolumn{3}{|c|}{ Wind Speed Class } & & & & & \\
\hline Wind from & Total & 0 & 1 & 2 & 3 & 4 & 5 & 6 & 7 & 8 \\
\hline S & $1 \%$ & 3 & 16 & 14 & 3 & 1 & 0 & 0 & 0 & 0 \\
\hline SSE & $0 \%$ & 6 & 10 & 7 & 3 & 1 & 3 & 0 & 0 & 0 \\
\hline SE & $1 \%$ & 11 & 17 & 20 & 18 & 6 & 2 & 0 & 0 & 0 \\
\hline ESE & $7 \%$ & 21 & 26 & 76 & 155 & 132 & 44 & 1 & 0 & 0 \\
\hline $\mathrm{E}$ & $41 \%$ & 28 & 43 & 261 & 790 & 1107 & 462 & 40 & 0 & 0 \\
\hline ENE & $21 \%$ & 29 & 42 & 158 & 494 & 530 & 156 & 12 & 0 & 0 \\
\hline $\mathrm{NE}$ & $6 \%$ & 30 & 55 & 120 & 143 & 88 & 2 & 0 & 0 & 0 \\
\hline NNE & $10 \%$ & 54 & 102 & 155 & 230 & 164 & 8 & 1 & 0 & 0 \\
\hline $\mathrm{N}$ & $7 \%$ & 64 & 51 & 114 & 176 & 97 & 5 & 0 & 0 & 0 \\
\hline NNW & $0 \%$ & 10 & 19 & 3 & 3 & 0 & 0 & 0 & 0 & 0 \\
\hline NW & $1 \%$ & 2 & 10 & 21 & 12 & 1 & 0 & 0 & 0 & 0 \\
\hline WNW & $0 \%$ & 1 & 4 & 8 & 11 & 2 & 1 & 0 & 0 & 0 \\
\hline $\mathrm{W}$ & $1 \%$ & 4 & 8 & 19 & 13 & 2 & 0 & 0 & 0 & 0 \\
\hline WSW & $0 \%$ & 3 & 10 & 11 & 4 & 0 & 0 & 0 & 0 & 0 \\
\hline SW & $0 \%$ & 1 & 9 & 7 & 1 & 0 & 0 & 0 & 0 & 0 \\
\hline SSW & $0 \%$ & 4 & 16 & 10 & 1 & 0 & 0 & 0 & 0 & 0 \\
\hline & Total & $4 \%$ & $7 \%$ & $15 \%$ & $31 \%$ & $32 \%$ & $10 \%$ & $1 \%$ & $0 \%$ & $0 \%$ \\
\hline & ulative & $4 \%$ & $11 \%$ & $26 \%$ & $57 \%$ & $89 \%$ & $99 \%$ & $100 \%$ & $100 \%$ & $100 \%$ \\
\hline
\end{tabular}

